UNIVERSIDADE DE SÃO PAULO

Escola de Engenharia de São Carlos

PROGRAMA DE PÓS-GRADUAÇÃO EM ENGENHARIA MECÂNICA

\title{
Avaliação da retificação com rebolo de CBN vitrificado aplicada em ligas de alto desempenho
}

\author{
Jen Po Wang
}

Dissertação apresentada à Escola de Engenharia de São Carlos, da Universidade de São Paulo, como parte dos requisitos para obtenção do título de Mestre em Engenharia Mecânica.

Orientador: Prof. Titular Dr. João Fernando Gomes de Oliveira

São Carlos

2008 


\section{DEDICATÓRIA}

Aos meus pais Hsiu Mei e Chin Shen, pelo amor, carinho e esforço dispensado para me proporcionar uma boa formação.

Ao meu irmão Chen Ping, à minha namorada Ya Mei pelo incentivo. Dedico este trabalho, com todo meu afeto. 


\section{AGRADECIMENTOS}

Agradeço primeiramente e especialmente à Deus por ter me concedido saúde, disposição e capacidade para a realização desta pesquisa científica.

Ao Prof. Titular João Fernando Gomes de Oliveira, pela excelente orientação fornecida durante a elaboração deste trabalho, pelas valiosas sugestões, pela amizade, paciência e ensinamentos transmitidos.

A Irene, pela amizade, carinho, pelos conselhos e pela valiosa ajuda dada durante toda essa caminhada.

Ao pessoal do OPF, Dinho, Fábio, Thiago, Luciano, Adolfo, Ariel, Lincoln, Arai, Marcelo, Luciano, Alex, Cristiano, pela colaboração e pela convivência harmoniosa.

Às empresas TRW, Zema, Saint Gobain e Micro Química por terem cedido o material e as informações necessárias para o desenvolvimento deste trabalho.

Agradeço à CAPES, pelo concessão da bolsa de mestrado, que foi de fundamental importância para o desenvolvimento desta pesquisa.

A todos aqueles que de alguma maneira contribuíram, direta ou indiretamente, com este trabalho, e que por ventura possa ter esquecido de citar. 


\section{SUMÁRIO}

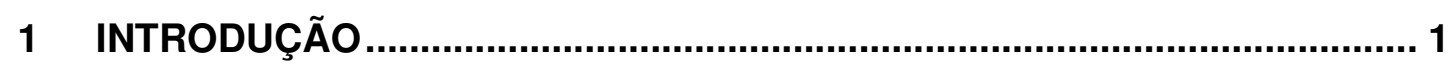

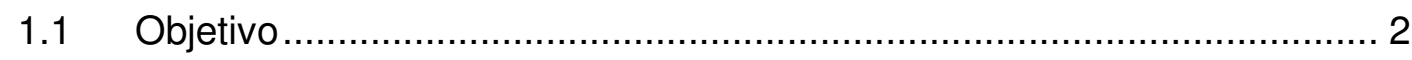

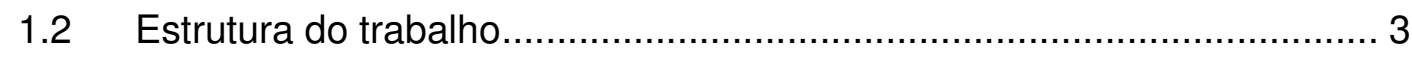

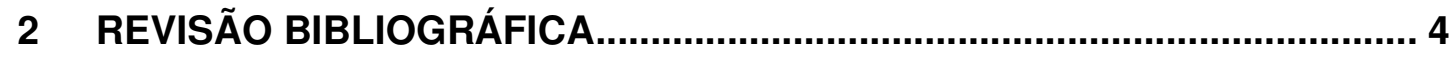

2.1 Características da tecnologia HSG .................................................. 4

2.1.1 Geometria do cavaco em HSG................................................ 4

2.1.2 Características construtivas de rebolos para altas velocidades ........... 9

2.2 Requisitos técnicos para a retificação com rebolos de CBN em altas

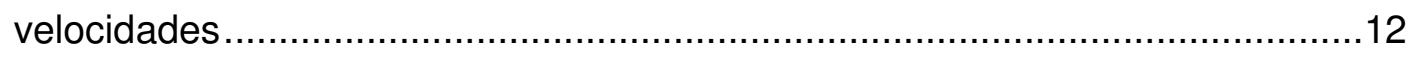

2.2.1 Características técnicas dos rebolos de CBN .................................12

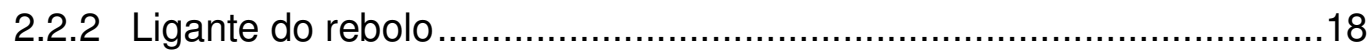

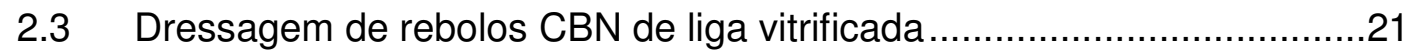

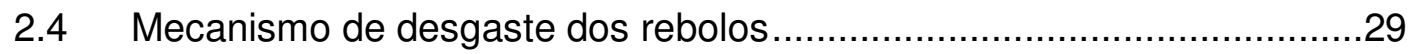

2.5 Monitoramento por Emissão Acústica (EA) .............................................31

2.5.1 Sistema de mapeamento acústico.....................................................36

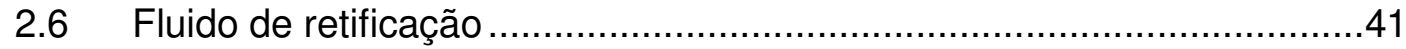

2.6.1 Classificação dos fluidos de corte ......................................................43

2.7 Retificação de superligas a base de níquel...........................................46

2.7.1 Integridade superficial e as relações de parâmetros na retificação de superligas à base de níquel ......................................................................

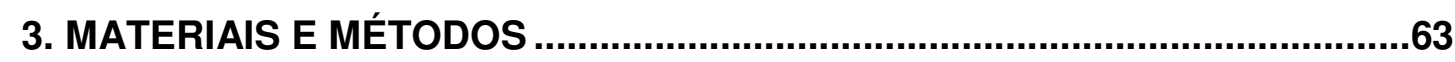

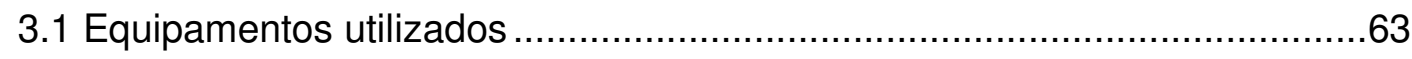

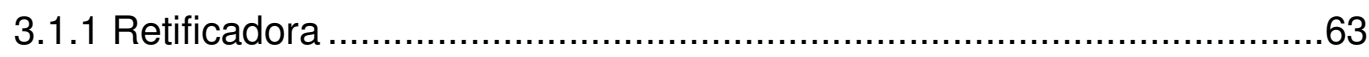

3.1.2 Rebolo, dressador e parâmetro de dressagem .......................................64

3.2 Equipamentos do sistema de aquisição de dados ......................................65

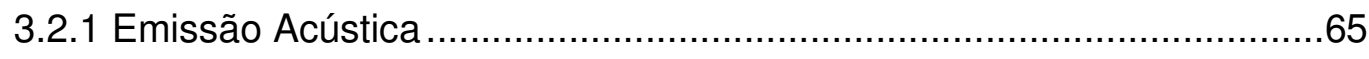

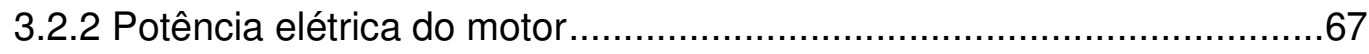


3.3 Medição da rugosidade e circularidade ..............................................68

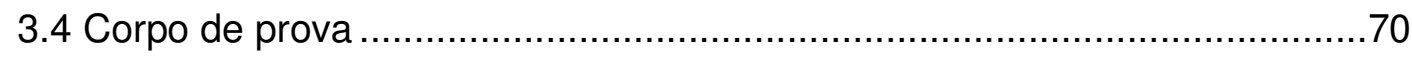

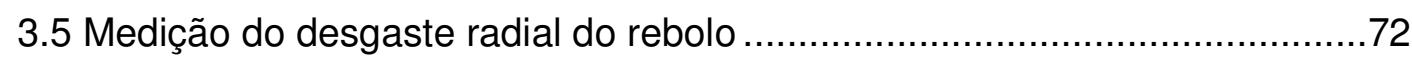

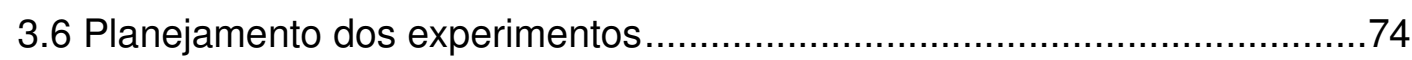

4. RESULTADOS E DISCUSSÃO ..................................................................76

4.1 Avaliação dos parâmetros de rugosidade .............................................76

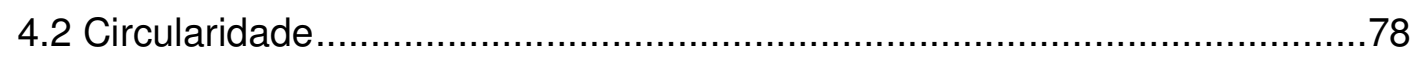

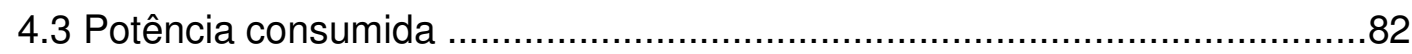

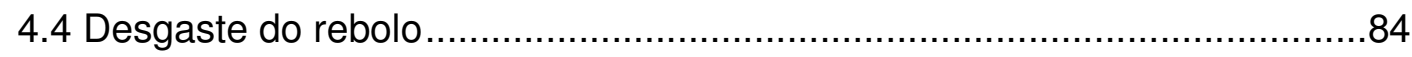

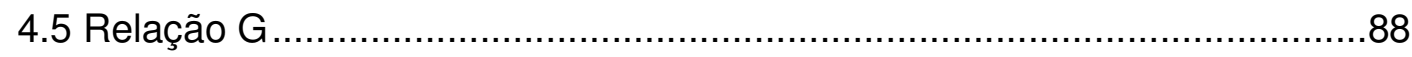

4.6 Análise da força em um grão abrasivo........................................90

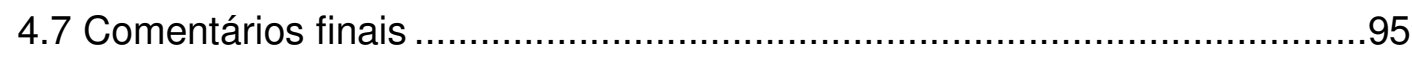

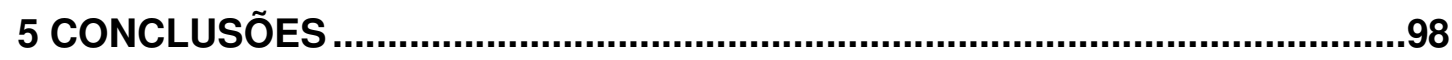

6. SUGESTÕES PARA TRABALHOS FUTUROS ......................................100

7. REFERÊNCIAS BIBLIOGRÁFICAS ......................................................101

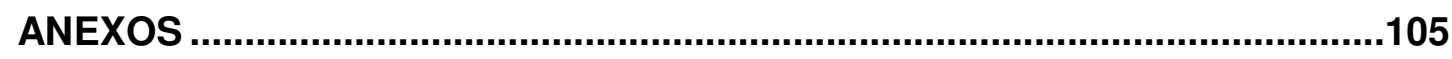




\section{LISTA DE FIGURAS}

Figura 2.1 - Temperatura da superfície da peça em função da velocidade periférica de rebolos CBN e óxido de alumínio (TAWAKOLI, 1993 apud SILVA, 2004 - Adaptada).

Figura 2.2 - Retificação a altas velocidades de corte com taxa de remoção de material constante (KLOCKE et al., 1997 - Adaptada)................................ 7

Figura 2.3 - Retificação a altas velocidades de corte com espessura do cavaco constante (KLOCKE et al., 1997 - Adaptada).

Figura 2.4 - Principais campos de aplicação da retificação a altas velocidades (JACKSON \& MILLS, 2004 - Adaptada).

Figura 2.5 - Análise de distribuição de tensões no rebolo (HITCHINER, 2001b)... 9

Figura 2.6 - Projeto de rebolo de alta velocidade usado a $500 \mathrm{~m} / \mathrm{s}$ (KONIG \& FERLEMANN, 1991 apud HITCHINER, 2001a, Adaptada).

Figura 2.7 - Microestrutura de rebolo de CBN (JACKSON et al., 2001). 13

Figura 2.8 - llustração de diversas porosidades do rebolo de CBN (Adaptada HITCHINER 2001a).

Figura 2.9 - Propriedades dos grãos convencionais e superabrasivos (Adaptada de CARIUS, 1999).

Figura 2.10 - A cinemática de entrada e saída do processo de retificação (CHEN et al., 2002).

Figura 2.11 - Alguns tipos de dressadores estáticos (esquerda) e rotativo (direita) existentes no mercado (HITCHINER, 2001b).

Figura 2.12 - Técnicas de dressagem (CHEN et al., 2002 - Adaptada). 24

Figura 2.13 - Circularidade dos rebolos com diferentes profundidades de dressagem (a) ad de $10 \mu \mathrm{m}$ e (b) ad de $3 \mu \mathrm{m}$ (CHEN et al., 2002).

Figura 2.14- O processo de dressagem monitorado pelo sinal de emissão acústica (HITCHINER, 2001b - Adaptada).

Figura 2.15 - Os efeitos de fraturas de diferente profundidade de dressagem

(Adaptada HITCHINER, 2001b).

Figura 2.16 - Região de contato entre dressador e rebolo (OLIVEIRA, 1988) ......27

Figura 2.17 - Ação do grau de recobrimento na topografia do rebolo (OLIVEIRA, 1988). 
Figura 2.18 - Mecanismos de desgaste (MALKIN, 1989 - Modificada).

Figura 2.19 - Mecanismos de desgaste (JACKSON \& MILLS, 2004). 31

Figura 2.20 - Aplicação de sensores comparado com o nível de precisão e parâmetro de controle de erros (LEE et al., 2006 - Adaptada).

Figura 2.21 - Fontes de emissão acústica em retificação (KARPUSCHEWISKI, 2001).

Figura 2.22 - Problemas na retificação (OLIVEIRA \& DORNFELD, 2001). 35

Figura 2.23 - Comparação de forças de retificação e sinal AE (BRINKSMEIER et al., 2005). 36

Figura 2.24 - Procedimento da construção do mapa acústico (OLIVEIRA \& DORNFELD, 2001).

Figura 2.25 - A marca $L$ produzido na superfície do rebolo corresponde a mapa EA durante a dressagem (LEE et al., 2006).

Figura 2.26 - Mapa obtido em duas operações distintas durante a operação de retificação (LEE et al., 2006).

Figura 2.27 - Exemplo de mapa acústico obtido no processo de retificação com vibrações (à direita).

Figura 2.28 - Classificação de superligas (CHOUDHURY \& EL-BARADIE, 1998).

Figura 2.29 - Gradiente térmico na retificação de "creep-feed" (SHAFTO, 1975 apud HOWES, 1990).

Figura 2.30 - Variação da temperatura no processo de retificação em função dos parâmetros de corte (TÖNSHOFF et al., 1992).

Figura 2.31 - Curva de temperatura e MEV da superfície da peça retificada (XU \& YU, 2002). 54

Figura 2.32 - Rugosidade superficial versos temperatura máxima (XU et al., 2002, modificada). 55

Figura 2.33 - Tensões residuais abaixo de superfície da peça (Xu et al., 2002). .56

Figura 2.34 - Efeito de tipos de grãos na variação de rugosidade em função de material removido (ICHIDA \& KISHI, 1997) ................................................57

Figura 2.35 - Efeito de tipos de grãos em função de relação de retificação $(G)$ em diversas condições (ICHIDA \& KISHI, 1997)...............................................58

Figura 2.36 - Efeito de tipos de grãos na variação de forças de retificação em função de aumento de material removido $(V s=2600 \mathrm{~m} / \mathrm{min}, \mathrm{Vw}=15 \mathrm{~mm} / \mathrm{min}$,

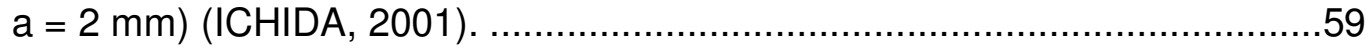


Figura 2.37 - Efeito de tipos de grãos na variação de desgaste radial e volumétrico do rebolo de retificação em função de aumento de material removido ( $\mathrm{Vs}=2600 \mathrm{~m} / \mathrm{min}, \mathrm{Vw}=15 \mathrm{~mm} / \mathrm{min}, \mathrm{a}=2 \mathrm{~mm})($ ICHIDA, 2001)...61

Figura 3.1 - Retificadora Zema G800 HS. 64

Figura 3.2 - Rebolo de superabrasivo de CBN. 65

Figura 3.3 - (a) unidade de tratamento de sinal de emissão acústica; (b) sensor sem contato. 66

Figura 3.4 - Tela principal do programa de aquisição de dados (VI). 67

Figura 3.5 - Esquema geral do sistema de monitoramento. 68

Figura 3.6 - Rugosímetro Mitutoyo SJ201. 69

Figura 3.7 - TALYROND131. .70

Figura 3.8 - Corpo de prova após ensaio de retificação. 71

Figura 3.9 - Medição de desgaste do rebolo através do mapa acústica. 72

Figura 3.10 - Medição de desgaste pela impressão do perfil. .73

Figura 4.1 - Comportamento da rugosidade para o material Inconel em função do volume específico de material removido V'w. .76

Figura 4.2 - Comportamento da rugosidade para o material Silcrome em função do volume específico de material removido V'w.

Figura 4.3 - Comportamento da rugosidade para o material 21-2N em função do volume específico de material removido V'w.

Figura 4.4 - Análise de circularidade do Inconel retificado com velocidade de avanço de $5 \mathrm{~mm} / \mathrm{min}$.

Figura 4.5 - Exemplo de especificação de forma e acabamento em duas regiões importantes de válvulas.

Figura 4.6 - Comportamento da circularidade para o material Inconel em função do volume específico de material removido V'w.

Figura 4.7 - Comportamento da circularidade para o material Silcrome em função do volume específico de material removido V'w.

Figura 4.8 - Comportamento da circularidade para o material 21-2N em função do volume específico de material removido V'w.

Figura 4.9 - Comportamento da potência para o material Inconel em função do volume específico de material removido V'w. 
Figura 4.10 - Comportamento da potência para o material Silcrome em função do volume específico de material removido V'w. 83

Figura 4.11 - Comportamento da potência para o material 21-2N em função do volume específico de material removido V'w.

Figura 4.12 - Comportamento do desgaste radial para o material Inconel em função do volume específico de material removido V'w.

Figura 4.13 - Comportamento do desgaste radial para o material Silcrome em função do volume específico de material removido V'w.

Figura 4.14 - Comportamento do desgaste radial para o material 21-2N em função do volume específico de material removido V'w. .86

Figura 4.15 - Mapa acústico de dressagem com 6 passes de 0.5 microns. .87

Figura 4.16 - Comparação dos valores de $\mathrm{G}$ em diferentes velocidades de avanço (Vf) na retificação de Inconel. 88

Figura 4.17 - Comparação dos valores de $\mathrm{G}$ em diferentes velocidades de avanço (Vf) na retificação de Silcrome. 89

Figura 4.18 - Comparação dos valores de $\mathrm{G}$ em diferentes velocidades de avanço (Vf) na retificação de 21-2N.

Figura 4.19 - Comportamento de Ft1g para o material Inconel em função do volume específico de material removido V'w.

Figura 4.20 - Comportamento de Ft1g para o material Silcrome em função do volume específico de material removido V'w.

Figura 4.21 - Comportamento de Ft1g para o material 21-2N em função do volume específico de material removido V'w. .........................................................92

Figura 4.22 - A relação entre força tangencial de estabilização em um único grão abrasivo e a relação $\mathrm{G}$. 93

Figura 4.23 - Curva característica do rebolo CBN. .94

Figura 4.24 - A relação entre força tangencial de estabilização em um único grão abrasivo e a rugosidade. .95 


\section{LISTA DE TABELAS}

Tabela 1 - Comparação entre as propriedades do aço e fibra de carbono (KLOCKE et al., 1997)...................................................................12

Tabela 2 - Porcentagem de consumo de CBN por indústria (Adaptado de CARIUS, 1999).

Tabela 3 - Impactos no rendimento de um rebolo superabrasivo de CBN em virtude de alterações dos grãos e ligante (BIANCHI et al., 1999).

Tabela 4 - Evolução de uso dos principais ligantes para rebolos superabrasivos (BIANCHI et al., 1999).

Tabela 5 - Composição química nominal (\% peso) e densidade das superligas à base de níquel forjadas (CHOUDHURY \& BARADIE, 1998 e EZUGWU et al., 1999)

Tabela 6 - Composição química do corpo de prova (\%). .....................................71

Tabela 7 - Matriz experimental dos ensaios de desgaste......................................74

Tabela 8 - Resultado da simulação. ………………..........................................96 


\section{LISTA DE ABREVIATURAS E SIGLAS}

CBN - Nitreto Cúbico de Boro.

CFC - Cúbico de face centrada.

CNC - Comando Numérico Computadorizado.

DTG - Difícil de ser retificado ("Difficult To Grind").

EA - Emissão Acústica.

HSG - Retificação em altas velocidades ("High Speed Grinding”).

MEV - Microscópio eletrônico de varredura.

RMS - Valor médio quadrático ("Root Mean Square").

$\mathrm{VI}$ - Instrumento virtual (“Virtual Instrument”). 


\section{LISTA DE SÍMBOLOS}

a - Profundidade de corte $[\mathrm{mm}]$.

$\mathrm{a}_{\mathrm{d}}-$ Profundidade de dressagem [mm].

$\mathrm{d}_{\mathrm{e}}-$ Diâmetro de equivalente $d_{e}=\frac{d_{s}}{1 \pm \frac{d_{s}}{d_{w}}}[\mathrm{~mm}]$.

$\mathrm{d}_{\mathrm{s}}$ - Diâmetro de rebolo [mm].

$\mathrm{d}_{\mathrm{w}}$ - Diâmetro da peça $[\mathrm{mm}]$.

E - Módulo de elasticidade do material $\left[\mathrm{N} / \mathrm{m}^{2}\right]$.

$\mathrm{f}_{\mathrm{r}}$ - Freqüência de rotação do rebolo $[\mathrm{Hz}] f_{r}=\frac{\text { rpm.rebolo }}{60}$

$\mathrm{F}_{\mathrm{n}}-$ Força normal de retificação $[\mathrm{N}]$.

$\mathrm{F}_{\mathrm{n}}^{\prime}$ - Força normal específica de retificação $[\mathrm{N}]$.

$\mathrm{F}_{\mathrm{t}}-$ Força tangencial de retificação $[\mathrm{N}]$.

$\mathrm{F}_{\mathrm{t}} 1 \mathrm{~g}$ : Força tangencial de estabilização em um grão abrasivo [N]

$G$ - Relação entre o volume de material retificado e o volume de rebolo desgastado.

$h_{m}$ - Espessura do cavaco indeformado [mm].

$\mathrm{N}_{\mathrm{r}}$ - Rotação de dressador [rpm].

$\mathrm{N}_{\mathrm{w}}$ - Rotação da peça [rpm].

$P_{c}$ - Potência de corte $[\mathrm{W}]$.

$q_{d}$ - Relação de velocidade entre o rebolo e o dressador.

$Q_{w}-$ Taxa de remoção de material $\left[\mathrm{mm}^{3} / \mathrm{s}\right]$.

$Q_{w}^{\prime}-$ Taxa de remoção específica de material $\left[\mathrm{mm}^{3} / \mathrm{mm} . \mathrm{s}\right]$.

$r$ - Raio de rebolo [mm].

$\mathrm{s}_{d}-$ Passo de dressagem [mm]. 
$t_{a}-$ Tempo de alisamento ou spark-out [s].

$\bigcup_{d}-$ Grau de recobrimento de dressagem $U_{d}=\frac{a_{d}}{s_{d}}$.

$v_{d}-$ Velocidade de dressagem $[\mathrm{mm} / \mathrm{min}]$.

$v_{f}$ - Velocidade de avanço [mm/min].

$v_{r}-$ Velocidade do disco dressador $[\mathrm{m} / \mathrm{s}]$.

$\mathrm{v}_{\mathrm{s}}-$ Velocidade do rebolo $[\mathrm{m} / \mathrm{s}]$

$\mathrm{v}_{\mathrm{w}}$ - Velocidade da peça $[\mathrm{m} / \mathrm{s}]$.

$\mathrm{V}_{\mathrm{w}}-$ Volume de material removido da peça $\left[\mathrm{mm}^{3}\right]$.

$V_{w}^{\prime}$ - Volume específico de material removido da peça $\left[\mathrm{mm}^{3} / \mathrm{mm}\right]$. 


\section{RESUMO}

WANG, P. JEN (2008). Avaliação da retificação com rebolo de CBN aplicada em ligas de alto desempenho. São Carlos, 2008. Dissertação - Escola de Engenharia de São Carlos, Universidade de São Paulo.

Superligas à base de níquel têm uma grande variedade de aplicações, por exemplo, turbinas a gás de aviões, câmaras de combustão, válvulas de motores, etc. As suas principais propriedades são alta resistência mecânica às temperaturas elevadas $\left(>500^{\circ} \mathrm{C}\right)$, alta resistência à abrasão, alta resistência à fadiga e boa resistência à corrosão. Por isso, são considerados materiais difíceis de serem retificados (ou Difficult To Grind - DTG). Condições severas de retificação em superligas podem causar altas temperaturas de corte (podendo atingir $1000^{\circ} \mathrm{C}$ ) e altas tensões (pressão) na região de contato (podendo chegar a $3450 \mathrm{MPa}$ ), o que leva ao desenvolvimento rápido do desgaste do rebolo, dependendo das suas características e da severidade das condições de corte. A melhoria do processo de retificação pode ser atingida com a utilização de grãos superabrasivos mais duros, como o CBN. O CBN apresenta um alto desempenho na usinagem e sua aplicação tem como principais vantagens: a redução dos tempos de ciclo, melhor qualidade e aumento de produtividade. $O$ desgaste da ferramenta de corte nos diversos processos de fabricação é de extrema importância no custo total da produção, portanto, na retificação de superligas, o desgaste do rebolo CBN dever ser mínimo devido ao seu alto custo. O presente trabalho avalia o desempenho de um rebolo de CBN vitrificado na retificação dos materiais Inconel 751, Silcrome 1 e 21-2N. Testes foram realizados variando-se apenas a velocidade de avanço para determinar a influência deste no desgaste do rebolo. Foi possível assim, determinar a relação entre o desgaste da ferramenta e a força tangencial em um grão, obtendo-se uma curva caracteristica do rebolo.

Palavras-chave: Retificação em altas velocidades, Rebolo de CBN, Difícil de ser retificado - DTG. 


\begin{abstract}
WANG, P. JEN (2008). Evaluation of CBN grinding of high performance alloys. São Carlos Engineering School, University of São Paulo, São Carlos, 2008.

Nickel-based superalloys have a great variety of applications, for example, aircraft gas turbines, combustion chambers, engines valves, etc. Their main properties are high strength at high temperatures $\left(>500^{\circ} \mathrm{C}\right)$, high resistance to the abrasion, high fatigue strength and good resistance to the corrosion. Therefore, they are considered difficult to grind (DTG) materials. Severe grinding conditions of superalloys can cause high cutting temperatures (able to reach $1000^{\circ} \mathrm{C}$ ) and high tensions in the contact zone (able to reach $3450 \mathrm{MPa}$ ). This leads to the fast development of the wear of CBN wheels, depending on the tool characteristics and the severity of the cutting conditions. The improvement of the grinding process can be reached with the use of harder superabrasive grains, as the CBN. The CBN presents high performance in machining. The main advantages are: the reduction of the cycle times, better quality and increase of productivity. The wheel wear is extreme important in the total production cost, therefore, in the grinding of superalloys, the wear CBN wheels have to be minimum due to its high cost. The present work evaluates the performance of vitrified CBN wheels in the grinding process of Inconel 751, Silcrome 1 e 21-2N. Tests were carried out varying the feed-rate to establish its influence on the wheel wear. It was possible to determine the relation between tool wear and tangential force per grain, obtaining the wheel characteristic curve.
\end{abstract}

Keywords: High Speed Grinding - HSG, CBN wheels, Difficult to Grind - DTG. 


\section{INTRODUÇÃO}

No mundo dos negócios, a competitividade sempre foi sinônima de capacidade de sobreviver, superar obstáculos e prosperar. As organizações, ao longo de suas existências, sempre buscaram, ainda que de modo empírico, caminhos para sua sobrevivência e manutenção no mercado competitivo.

Esta década passa a caracterizar-se pelo aumento, em nível mundial, de uma busca por métodos e ferramentas que resultem na diminuição dos custos de produção, aumento da produtividade e maior qualidade (KING \& HAHN, 1986).

$\mathrm{Na}$ cadeia produtiva, um dos processos de acabamento mais utilizados na fabricação de peças de precisão é o de retificação, sendo responsável pela obtenção de altos níveis de qualidades geométricas, dimensionais e superficiais. É também o menos dominado e conhecido quando comparado aos métodos convencionais de usinagem (torneamento, fresamento e furação por exemplo), desta forma, o seu desempenho é extremamente dependente da habilidade e experiência do operador e das condições de usinagem e dressagem de rebolo (OLIVEIRA, 1988). De forma geral, a tecnologia da retificação em altas velocidades (HSG) tornar-se o caminho certo a ser trilhado na busca da competitividade em curtíssimo espaço de tempo.

Os problemas do processo de retificação dividem-se basicamente em três grandes grupos: a falta de dados consistentes para a especificação de uma nova operação; a inconsistência de uma operação já especificada que passa a não fornecer mais as qualidades desejadas e a falta de informações e experiência para a aplicação de novas tecnologias (OLIVEIRA, 1988).

As superligas à base de níquel têm uma grande variedade de aplicações, por exemplo: turbinas do avião, câmaras de combustão, válvulas de admissão/escape, etc. As suas principais propriedades são: alta resistência mecânica às temperaturas elevadas $\left(>500^{\circ} \mathrm{C}\right)$, alta resistência à fluência, alta resistência à fadiga e boa resistência à corrosão, por isso, são considerados materiais difíceis de serem retificados (Difficult To Grind - DTG). 
Segundo Klocke \& König (1995), a melhoria do processo de retificação pode ser atingida com a utilização de grãos superabrasivos como CBN (Nitreto Cúbico de Boro). $\mathrm{O}$ alto desempenho deste material abrasivo resulta da sua extrema dureza e resistência ao desgaste, aliadas às altas resistências à temperatura e condutividade térmica.

Atualmente, existe uma grande utilização de rebolos de CBN no mercado, abrangendo indústrias tais como: as automobilísticas; aeroespaciais; de componentes de motores, etc. Embora o rebolo de CBN tenha um elevado custo inicial quando comparado com rebolos convencionais, sua aplicação é compensada desde que o custo operacional total por peça produzida seja reduzido (BIANCHI, 1992).

No entanto, deve-se salientar que a literatura disponível é muito limitada em termos de informações para retificação das superligas à base de níquel, principalmente com CBN e em altas velocidades. Por essa razão, cuidados especiais devem ser tomados para assegurar a vida do rebolo e a integridade superficial adequada do componente usinado por intermédio de controle dos principais parâmetros de retificação.

Sabe-se que aplicações industriais de CBN em superligas têm sido difíceis na indústria, tendo em vista que os rebolos podem sofrer um desgaste muito maior que o esperado, dependendo da severidade das condições de usinagem.

Diversos estudos já mostraram a maior vida do rebolo de CBN em relação a rebolos convencionais para materiais convencionais, deste modo, sabe-se que a utilização do mesmo gera uma maior economia no processo como um todo. No entanto, é preciso entender como é a relação entre a severidade da operação de retificação e a vida do rebolo de $\mathrm{CBN}$ no caso da retificação de superligas a base de Níquel.

\subsection{Objetivos}

Este trabalho tem como principais objetivos:

- O estudo da retificação com altas velocidades e rebolos de CBN aplicado à superligas, verificando assim, as possibilidades de melhoria do processo; 
- Avaliar o desempenho do rebolo de CBN na retificação de superligas, observando o desgaste volumétrico do rebolo e a qualidade superficial da peça retificada em função da severidade das condições de trabalho;

- Estudar a influência da velocidade de avanço (Vf) do rebolo de CBN em relação da qualidade da peça e potência consumida no processo de retificação.

\subsection{Estrutura do trabalho}

O presente trabalho está dividido em capítulos, cujos conteúdos são descritos abaixo:

Revisão bibliográfica: Este capítulo refere-se à revisão bibliográfica e tem como objetivo apresentar os conceitos teóricos relacionados à retificação em altas velocidades, bem como as principais características das aplicações do rebolo de CBN (Nitreto Cúbico de Boro) e suas condições de utilização.

Materiais e Métodos: Nesse capítulo é descrito o planejamento e o procedimento experimental dos ensaios.

Resultados e Discussões: Neste capítulo são apresentados os resultados dos ensaios e também é feito um comentário entre as variáveis de saída do processo obtidas. Estas análises comparativas permitirão avaliar o desempenho do processo de retificação em altas velocidades de superligas com rebolos de CBN.

Conclusão: Este capítulo relaciona as conclusões mais relevantes dos resultados da pesquisa realizada. 


\section{REVISÃO BIBLIOGRÁFICA}

\subsection{Características da tecnologia HSG}

\subsubsection{Geometria do cavaco em HSG}

A retificação em altas velocidades (ou do Inglês High Speed Grinding HSG) tem sido alvo de intensa pesquisa nos últimos 20 anos, conduzida por promessas de taxas mais elevadas de remoção de material bruto e vida mais longa do rebolo. Este processo oferece potencial excelente para boa qualidade superficial combinada com alta produtividade (HITCHINER, 2001a).

Há poucos anos, velocidades periféricas de rebolos acima de $50 \mathrm{~m} / \mathrm{s}$ eram consideradas altas. Hoje, no entanto, velocidades entre 50 e $125 \mathrm{~m} / \mathrm{s}$ estão se tornando comuns. Os rebolos para velocidades acima de $250 \mathrm{~m} / \mathrm{s}$ estão sendo estudados em laboratórios e universidades. .

Estes desenvolvimentos estão principalmente relacionados com as novas máquinas retificadoras e com os recursos do $\mathrm{CNC}$, mancais e guias hidrostáticas, além de motores que possibilitam altíssimas velocidades de corte e também melhorias nos rebolos, como a utilização de superabrasivos, granulometrias extremamente reduzidas e o desenvolvimento de ligantes especiais para essas novas condições (SCHUITEK et al., 2001).

O benefício trazido pelo aumento da velocidade é evidente, pois, segundo Klocke et al. (1997), a alta velocidade periférica do rebolo resulta na diminuição da espessura de cavaco. A redução da espessura do cavaco melhora a rugosidade superficial, reduz as forças de corte e o desgaste do rebolo.

Segundo Hitchiner (2001a), o aumento da velocidade de corte acima de $100 \mathrm{~m} / \mathrm{s}$ provoca a redução de temperatura da superfície da peça, conforme apresentado na Figura 2.1. Nestas velocidades, o tempo de contato do grão com a peça é tão pequeno que o processo térmico torna-se adiabático, já que o calor não tem tempo suficiente para se propagar em direção a peça antes de ser removido pelo cavaco. Com a redução da temperatura da peça, reduz-se a probabilidade do aparecimento de danos térmicos como a queima ou trincas.

De acordo com Klocke et al. (1997) e Silva (2004), o aumento de velocidade de corte $\left(\mathrm{v}_{\mathrm{c}}\right)$ normalmente não é acompanhado pela redução 
proporcional da força tangencial de retificação, resultando no aumento do calor gerado. Isto pode ser visto na Figura 2.1 para as velocidades de corte de 60 a $100 \mathrm{~m} / \mathrm{s}$. No entanto, para velocidades maiores do que $100 \mathrm{~m} / \mathrm{s}$, apesar do processo de retificação gerar ainda mais calor, a temperatura no contato rebolopeça diminui.

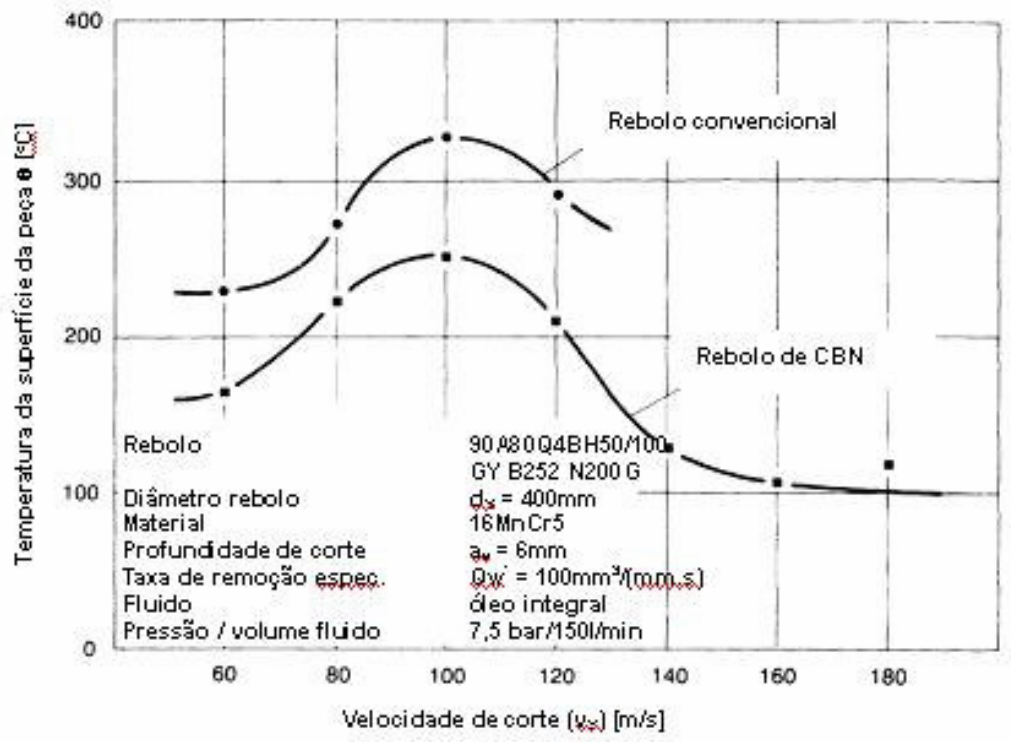

Figura 2.1 - Temperatura da superfície da peça em função da velocidade periférica de rebolos CBN e óxido de alumínio (TAWAKOLI, 1993 apud SILVA, 2004 - Adaptada).

Kopac \& Krajnik (2006) mostram que existe uma dependência funcional entre a espessura média do cavaco indeformado $\left(h_{c u}\right)$ e as variáveis de entrada: velocidade periférica do rebolo $\left(v_{s}\right)$, velocidade tangencial da peça $\left(v_{w}\right)$ e a profundidade de corte $(a)$, bem como o diâmetro equivalente do rebolo $\left(d_{\text {eq }}\right)$ e a densidade estática das arestas de corte $\left(C_{\text {stat }}\right)$. Essa dependência pode ser descrita pela seguinte função exponencial:

$$
h_{c u} \approx k\left[\frac{1}{C_{s t a t}}\right]^{\alpha}\left[\frac{V_{w}}{V_{c}}\right]^{\beta}\left[\frac{a}{d_{e q}}\right]^{\gamma}
$$

Onde $k$ é um fator de proporcionalidade e $\alpha, \beta$ e $\gamma$ são expoentes experimentais positivos. 
O segundo modelo é referente à espessura máxima do cavaco $h_{m}$ :

$$
h_{m} \approx c_{g w}\left[\frac{V_{w}}{V_{s}}\right]^{e}\left[\frac{a}{d_{e q}}\right]^{\frac{e}{2}}
$$

Onde, $c_{g w}$ é uma constante de topografia do rebolo, e o expoente e é positivo.

O diâmetro equivalente $\left(d_{\text {eq }}\right)$ é dado por (MALKIN, 1989):

$$
d_{e q}=\frac{d_{s}}{1 \pm d_{s} / d_{w}}
$$

Onde $d_{s}$ é o diâmetro do rebolo, $d_{w}$ é o diâmetro da peça e o sinal positivo representa a operação cilíndrica externa enquanto que o negativo a operação cilíndrica interna.

$\mathrm{Na}$ base destes relacionamentos pode-se estabelecer que um aumento na velocidade de corte com todas as outras variáveis constantes, resultará em uma redução na espessura do cavaco e conseqüentemente na força de retificação. Isto pode ser utilizado para melhorar a qualidade da peça ou a taxa de remoção de material. O aumento na velocidade do corte, mantendo a taxa de remoção de material constante, como mostrada em Figura 2.2, resulta na redução das forças de retificação e do desgaste do rebolo, além de melhorar a precisão de forma e tamanho do componente retificado (KLOCKE et al., 1997). 


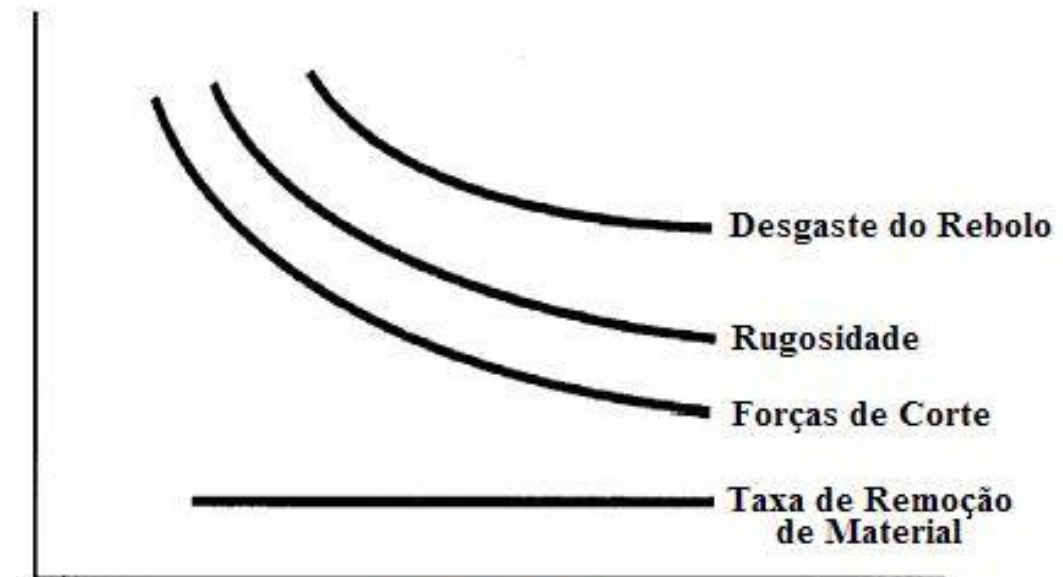

Velocidade de Corte

Figura 2.2 - Retificação a altas velocidades de corte com taxa de remoção de material constante (KLOCKE et al., 1997 - Adaptada).

O aumento da velocidade de corte e da taxa de remoção de material, mantendo-se a espessura do cavaco constante, como mostrada em Figura 2.3, resulta em valores constante das forças de retificação, do desgaste do rebolo e da rugosidade superficial da peça. Em termos tecnológicos, esta ilustração relacionase à alta produtividade HSG sem aumentar as forças de corte do processo.

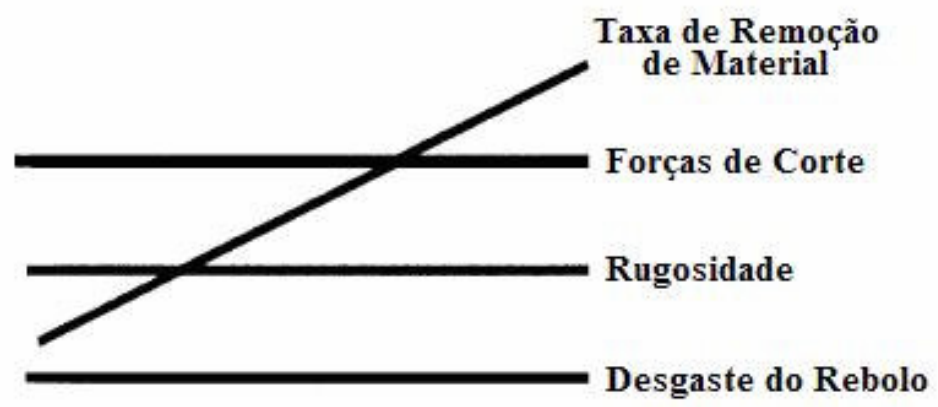

Velocidade de Corte

Figura 2.3 - Retificação a altas velocidades de corte com espessura do cavaco constante (KLOCKE et al., 1997 - Adaptada). 
De acordo com Jackson et al. (2001), existem três campos principais de estudo e aplicação da retificação a altas velocidades. Estes são:

- Retificação a altas velocidades com rebolos de CBN;

- Retificação a altas velocidades com rebolos de óxido de alumínio; e

- Retificação a altas velocidades com rebolos de óxido de alumínio em conjunto com técnicas de dressagem contínua (CD - Continuous Dressing).

A Figura 2.4, mostra a taxa de remoção de material versus a velocidade de corte para estes três principais campos (JACKSON \& MILLS, 2004).

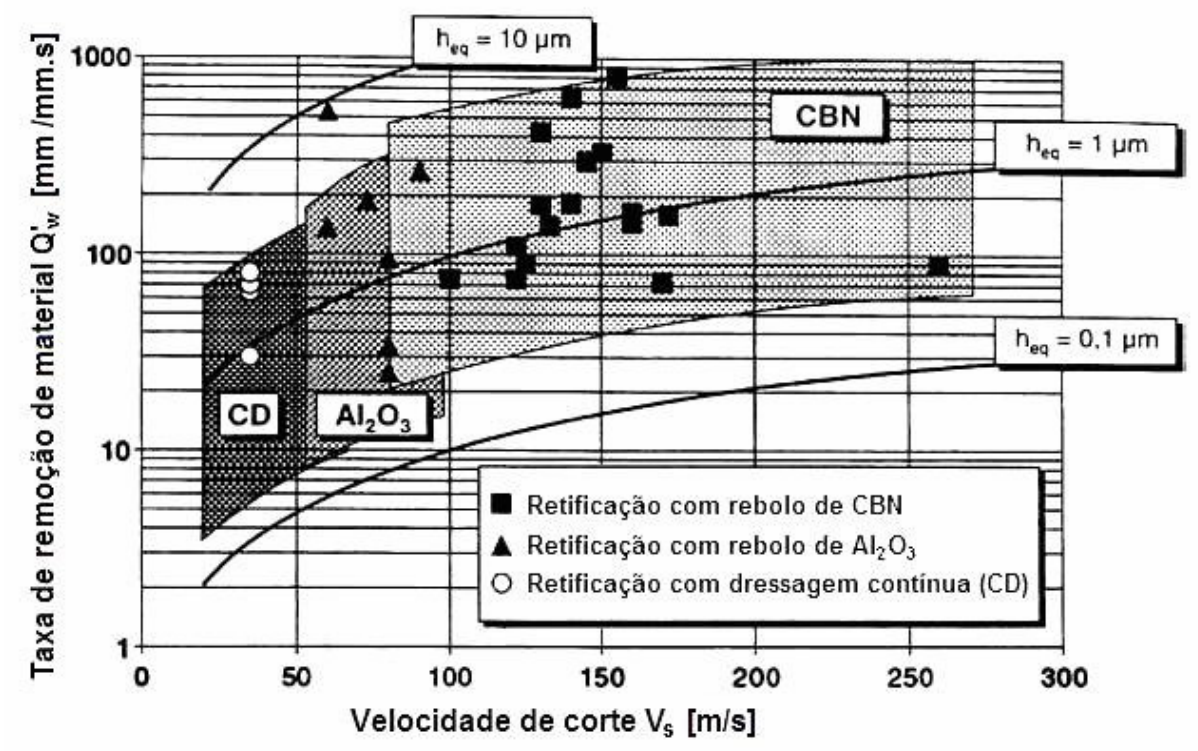

Figura 2.4 - Principais campos de aplicação da retificação a altas velocidades (JACKSON \& MILLS, 2004 - Adaptada).

A espessura equivalente do cavaco entre de 0.5 e 10 micrometros, é uma característica de retificação em alta velocidade. Essa dependência pode ser descrita pela seguinte função:

$$
h_{e q}=\frac{Q_{w}^{\prime}}{v_{s}}
$$


Oliveira (1988) relacionou o desgaste do rebolo com a espessura de corte equivalente no seu trabalho e observou que essas grandezas são inversamente proporcionais.

\subsubsection{Características construtivas de rebolos para altas velocidades}

Segundo Hitchiner (2001a), quando o rebolo gira, as tensões são maiores no furo. Para operar em alta velocidade é preciso, antes de tudo, um sistema que possa atuar com segurança na velocidade exigida. Os rebolos de CBN vitrificado são construídos como um anel de segmentos finos colados a um núcleo de aço. O material mais resistente do núcleo absorve as tensões mais elevadas, enquanto o aro vitrificado experimenta uma combinação de tensão radial, das forças centrífugas envolvidas, em conjunto com a tensão circular da expansão da força centrifuga no núcleo. Isto pode ser visto na Figura 2.5.
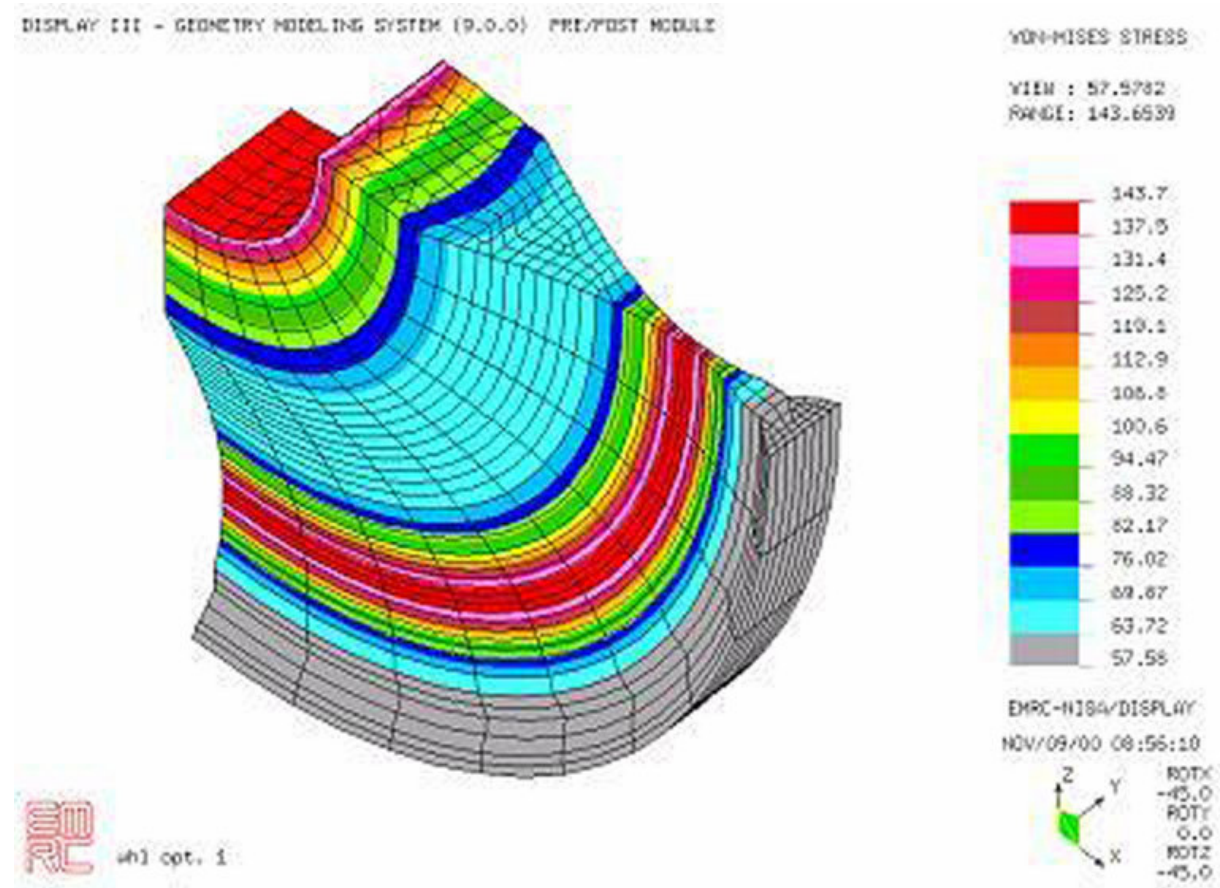

Figura 2.5 - Análise de distribuição de tensões no rebolo (HITCHINER, 2001b).

Um trabalho realizado por Yui \& Lee (1996), analisou a influência da velocidade de corte na dilatação (expansão dimensional) do rebolo de CBN. Os 
autores afirmam que o cálculo teórico da dilatação pode ser feito pela fórmula da Equação 5, obtendo-se grande precisão.

$$
u=\frac{\gamma \omega^{2}}{4 E g}(1-v) r^{3}
$$

Onde, $u$ é a dilatação do rebolo; $\gamma$ o peso específico do material do corpo de rebolo; $E$ o módulo de Young (ou elasticidade) do material do corpo; $\omega$ a velocidade angular; $g$ a aceleração da gravidade; $v$ o coeficiente de Poisson e $r o$ raio do rebolo.

Esta expansão gera erros na dimensão final da peça retificada. A expansão centrífuga afeta tanto o diâmetro externo quanto o furo, para as velocidades de operação mais elevadas, a expansão do diâmetro e do furo deve ser minimizada (HITCHINER, 2001a).

Deste modo, a eliminação do furo central e a otimização da forma do rebolo pela diminuição de sua espessura com o aumento do raio são muito importantes para a retificação a altas velocidades (KLOCKE et al., 1997).

Konig \& Ferlemann (1991) apud Hitchiner (2001a) relatam o projeto ilustrado na Figura 2.6. 


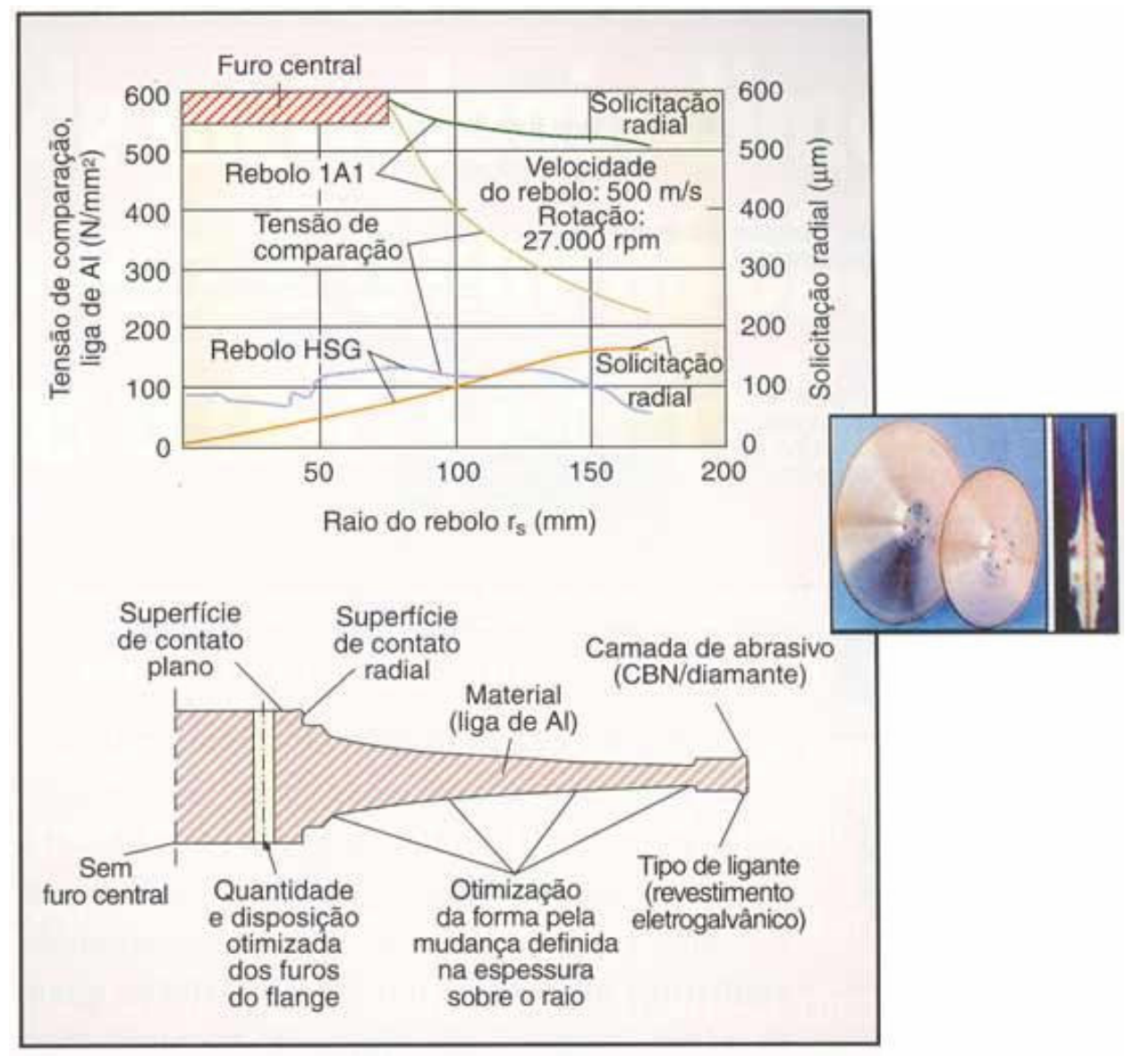

Figura 2.6 - Projeto de rebolo de alta velocidade usado a $500 \mathrm{~m} / \mathrm{s}$ (KONIG \& FERLEMANN, 1991 apud HITCHINER, 2001a, Adaptada).

Este projeto utiliza uma superfície de contato radial em um aro de flange para localizar o rebolo durante a montagem. Ele conta com a pressão de fixação de seis parafusos e atrito entre a superfície de rebolo e o suporte de fuso, para evitar o movimento radial que poderia provocar trepidação.

Segundo Klocke et al. (1997), a maioria dos rebolos superabrasivos têm um corpo de aço ou alumínio. A aplicação na manufatura de rebolos de outros tipos de materiais, por exemplo, a fibra de carbono (CFRP), estão sendo desenvolvidos no Japão e Europa. A comparação entre algumas das propriedades do aço e da fibra de carbono (CFRP) pode ser feita pela Tabela 1. 
Tabela 1 - Comparação entre as propriedades do aço e fibra de carbono (KLOCKE et al., 1997)

\begin{tabular}{|c|c|c|}
\hline Propriedades & Aço (S45C) & CFRP \\
\hline $\begin{array}{c}\text { Peso específico } \\
\boldsymbol{\gamma}\left[\mathrm{N} / \mathrm{dm}^{3}\right]\end{array}$ & 78.4 & 15.8 \\
\hline $\begin{array}{c}\text { Módulo de elasticidade } \\
\mathbf{E}\left[10^{3} \times \mathrm{N} / \mathrm{mm}^{2}\right]\end{array}$ & 200 & 70 \\
\hline $\mathbf{E} / \boldsymbol{\gamma}[\times 106 \mathrm{~m}]$ & 2.66 & 4.43 \\
\hline $\begin{array}{c}\text { Tensão de tração } \\
\boldsymbol{\sigma}_{\mathrm{y}}\left[\mathrm{N} / \mathrm{mm}^{2}\right]\end{array}$ & 650 & 470 \\
\hline $\begin{array}{c}\text { Coeficiente de expansão linear } \\
\boldsymbol{\alpha}\left[10^{-6} / \mathrm{K}\right]\end{array}$ & 12 & 1 \\
\hline
\end{tabular}

Apesar do módulo de elasticidade do CFRP ser menor do que o do aço, o seu peso específico é extremamente baixo e faz com que a relação $E / \gamma$ seja alta, o que é vantajoso no processo de retificação. De fato, a expansão provocada pelas altas velocidades tangenciais pode ser suprimida pelo uso de materiais no corpo do rebolo com altos valores da relação $\mathrm{E} / \gamma$. O valor extremamente baixo do coeficiente de expansão linear de CFRP apresenta outra vantagem na aplicação deste material no corpo de rebolo na retificação.

\subsection{Requisitos técnicos para a retificação com rebolos de CBN em altas velocidades}

\subsubsection{Características técnicas dos rebolos de CBN}

O CBN (nitreto cúbico de boro) foi introduzido no final de 1968 pela empresa General Eletric chamado na época de Borazon. Com sua singular composição química de boro e nitrogênio, se mantém inerte quando usado para retificar materiais propensos à formação de carbetos (CARIUS, 1999).

Segundo Salmon (1992), o grão de CBN é conhecido pela cor preta e opaca, e é formado através de um processo de sinterização realizado sob alta temperatura e pressão (1650 ${ }^{\circ} \mathrm{C}$ e 68.000 bar). Nesta condição extrema e na presença de um catalisador, elétrons dos átomos de nitrogênio migram para os 
átomos de boro, formando uma estrutura cristalina semelhante à estrutura do diamante. A Figura 2.7 mostra a microestrutura de rebolo de CBN.

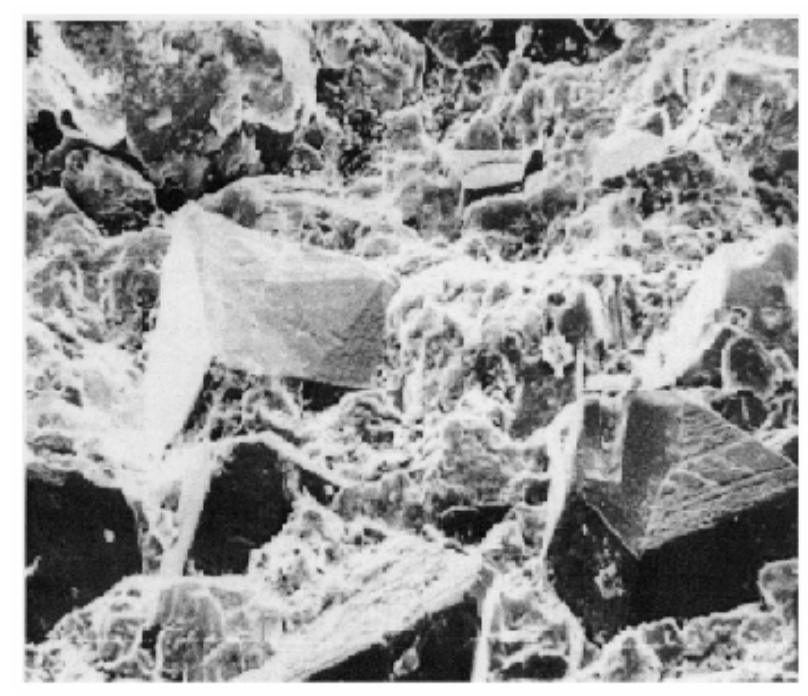

Figura 2.7 - Microestrutura de rebolo de CBN (JACKSON et al., 2001).

Apesar da extrema dureza do diamante, seu emprego na usinagem de aços, principalmente na dos hipoeutéticos, é dificultado pela tendência que o carbono do diamante tem de se difundir no ferro sob condições de pressão e temperatura usuais de usinagem. Além disso, comparado com o diamante, o CBN apresenta uma resistência elevada à temperatura. Enquanto nos diamantes a grafitização inicia a partir de $900{ }^{\circ} \mathrm{C}$, o nitreto cúbico de boro sob pressão atmosférica, apresenta estabilidade de até $2000{ }^{\circ} \mathrm{C}$ (SCHUITEK et al., 2001).

No entanto, o rebolo abrasivo feito com CBN mantém-se afiado para a retificação de metais ferrosos endurecidos, ferro fundido e superligas de níquel e cobalto, portanto, mostra-se atualmente como o grão abrasivo de alto desempenho para melhorar a qualidade da peça retificada e para a redução do custo operacional de retificação.

De acordo com Chen et al. (2002), a retificação com rebolos de CBN está sujeita ao uso de técnicas especiais, tais como: rebolos com alta porosidade para a usinagem de materiais de difícil corte, altas velocidades de corte, técnicas especiais de dressagem, sistema de refrigeração eficiente, dentre outras. As vantagens do rebolo de $\mathrm{CBN}$ só podem ser alcançadas quando todos os fatores 
importantes do processo forem controlados. A Figura 2.8 apresenta diversas porosidades para um rebolo de CBN.

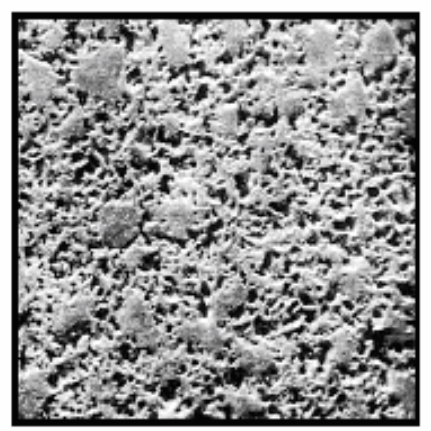

Baixa porosidade

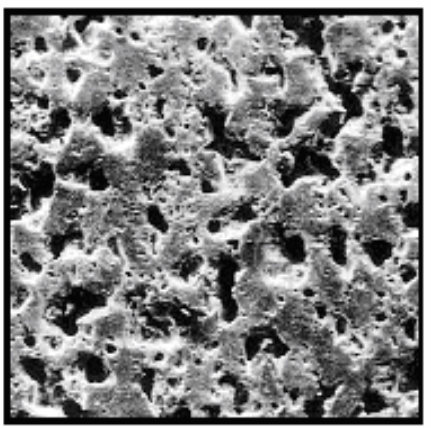

Média porosidade

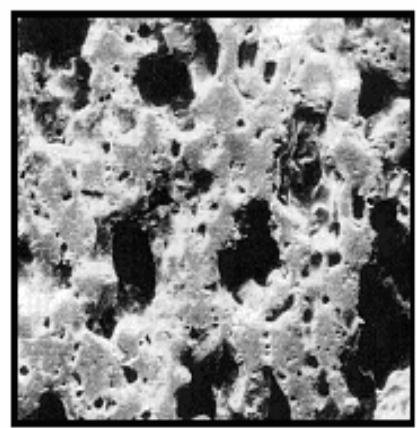

Alta porosidade

Figura 2.8 - llustração de diversas porosidades do rebolo de CBN (Adaptada HITCHINER 2001a).

A alta porosidade ajuda a transportar o fluido de corte para a interface de retificação, reduz a temperatura de contato e melhora a lubrificação, e também fornecer maior espaço evitando a tendência de empastamento de rebolo. Segundo Salmon (1992), rebolos com altas porosidades podem ser aplicados na retificação em alta velocidade com grande profundidade de passe (creep feed).

O CBN tem várias vantagens distintas sobre os abrasivos convencionais especialmente maior dureza, resistência à abrasão, à fratura e alta condutividade térmica. A Figura 2.9 mostra algumas propriedades dos grãos de CBN comparadas com as de outros materiais. 


\section{Dureza do material}

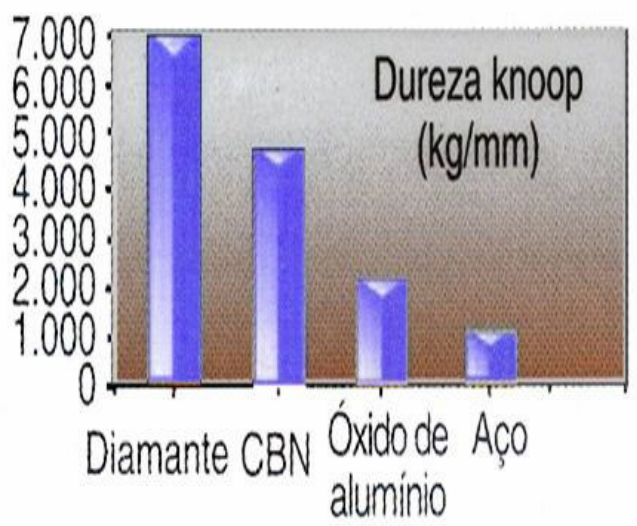

Condutividade térmica

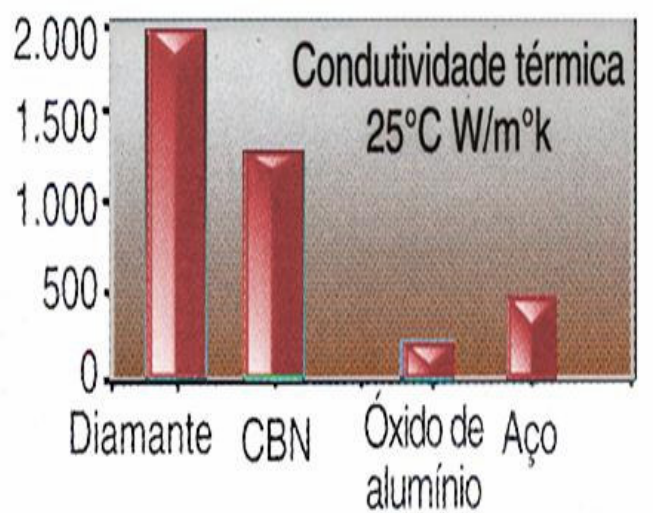

Figura 2.9 - Propriedades dos grãos convencionais e superabrasivos (Adaptada de CARIUS, 1999).

No processo típico de retificação, a geração instantânea de calor no ponto de contato de abrasão será menor com CBN do que óxido de alumínio, por causa de seu corte afiado e resistência à abrasão. Além disso, a maior parte de calor gerado será mais rapidamente disperso dentro da partícula de CBN (mais condutiva termicamente) do que óxido de alumínio (de menor condutividade térmica). Assim, menos energia térmica é transmitida através do material retificado com $\mathrm{CBN}$, resultando em temperaturas menores na peça trabalhada e formando tensões de compressão benéficos à peça. Estas características permitem ao rebolo de CBN um desempenho exponencialmente superior ao rebolo convencional.

A tendência para uma maior precisão na retificação e processamento de materiais difíceis de serem retificados, tais como ferro fundido nodular, aço carbono e forjado, metal sinterizado e superligas de níquel e cobalto, continuarão a motivar a conversão para retificação com CBN (CARIUS, 1999).

Embora a retificação de eixos de comando de válvulas tenha sido uma das mais dramáticas conversões e uma das maiores aplicações para o CBN, tanto na Europa quanto na América existem muitas outras aplicações para o CBN nesta indústria, incluindo aplicações em munhão de virabrequim, munhão de mancais, superfícies de encosto, válvulas, assento de válvulas, balancins, eixos, tuchos, roletes de excêntricos, cames, ressaltos, agulhas de injetor de combustível, bicos, 
corpos de bombas, mancais de turboalimentadores, faces de apoio, anéis de pistão, pinos, rotores, palhetas, válvulas para direção hidráulica e ar condicionado, bomba de ar, bomba de óleo, transmissões automáticas, culatra, anéis de rolamentos, pistas internas e externas para juntas universais e homocinética, válvulas de transmissão e corpos de válvulas. A Tabela 2 apresenta a porcentagem de consumo de CBN por indústria.

Tabela 2 - Porcentagem de consumo de CBN por indústria (Adaptado de CARIUS, 1999).

\begin{tabular}{|c|c|c|}
\hline Indústria & América (\%) & Europa (\%) \\
\hline Automotiva & 25 & 28 \\
\hline Mancais & 12 & 15 \\
\hline Aeroespacial & 18 & 6 \\
\hline Ferramentas \& matrizes & 19 & 10 \\
\hline Engrenagens & 7 & 20 \\
\hline Outros * & 19 & 100 \\
\hline Total & 100 & \\
\hline * Inclui eletrodomésticos, hidráulicos, máquinas-ferramenta, cutelaria, \\
instrumentos médicos, bombas, etc.
\end{tabular}

Um rebolo superabrasivo é fabricado para uma aplicação específica. Ou seja, os seus constituintes devem ser trabalhados de forma a se obter uma ferramenta de corte que atenda as necessidades do usuário. A Tabela 3 apresenta os impactos que ocorrem no rendimento de um rebolo superabrasivo de CBN devido às alterações dos grãos e ligantes. 
Tabela 3 - Impactos no rendimento de um rebolo superabrasivo de CBN em virtude de alterações dos grãos e ligante (BIANCHI et al., 1999).

\begin{tabular}{|c|c|c|c|c|c|c|c|c|}
\hline \multirow{3}{*}{$\begin{array}{l}\text { IMPACTOI } \\
\text { ALTERAÇÃO }\end{array}$} & \multicolumn{2}{|c|}{ Friabilidade } & \multicolumn{2}{|c|}{ Granulometria } & \multicolumn{2}{|c|}{ Concentração } & \multicolumn{2}{|c|}{ Dureza (ligante) } \\
\hline & Friável & $\begin{array}{c}+ \\
\text { Friável }\end{array}$ & Fina & Grossa & Baixa & Alta & Baixa & Alta \\
\hline & $\downarrow$ & $\uparrow$ & $\downarrow$ & $\uparrow$ & $\downarrow$ & $\uparrow$ & $\downarrow$ & $\uparrow$ \\
\hline $\begin{array}{c}\text { Taxa de } \\
\text { remoção de } \\
\text { material }\end{array}$ & $\downarrow$ & $\uparrow$ & $\downarrow$ & $\uparrow$ & $\downarrow$ & $\uparrow$ & $\downarrow$ & $\uparrow$ \\
\hline Relação G & $\downarrow$ & $\uparrow$ & $\downarrow$ & $\uparrow$ & $\downarrow$ & $\uparrow$ & $\downarrow$ & $\uparrow$ \\
\hline $\begin{array}{c}\text { Acabamento } \\
\text { superficial }\end{array}$ & $\downarrow$ & $\uparrow$ & $\uparrow$ & $\downarrow$ & $\downarrow$ & $\uparrow$ & $\downarrow$ & $\uparrow$ \\
\hline $\begin{array}{l}\text { Consumo de } \\
\text { energia da } \\
\text { máquina }\end{array}$ & $\uparrow$ & $\downarrow$ & $\downarrow$ & $\uparrow$ & $\downarrow$ & $\uparrow$ & $\downarrow$ & $\uparrow$ \\
\hline
\end{tabular}

Analisando a Tabela 3 (BIANCHI et al., 1999), o grau de friabilidade (facilidade para fraturar o grão em pedaços, sob uma determinada força de retificação ou impacto entre o grão e a peça, formando novas arestas) de um grão abrasivo também pode auxiliar o processo de usinagem. Se for utilizar um rebolo com maior grau de friabilidade, haverá uma renovação mais acentuada e constante das arestas de corte, fazendo com que o rebolo permaneça afiado. Conseqüentemente, a energia consumida é menor gerando-se menores forças, conseqüentemente menores deformações na máquina e menos erros de forma.

O grão abrasivo influencia diretamente a vida útil do rebolo, a eficiência da operação de retificação e a qualidade superficial da peça retificada. Numa determinada operação onde são desejáveis valores reduzidos de rugosidade superficial da peça, deve-se utilizar um rebolo fabricado com granulometria fina.

O ligante influencia a compatibilidade/retenção do abrasivo, a capacidade na obtenção de formas geométricas especiais do rebolo, a vida útil do rebolo e as características de desgaste deste. A alteração da dureza do ligante influencia diretamente as variáveis de saída do processo. De forma geral, pode se afirmar que se o ligante possuir baixa capacidade de retenção dos grãos abrasivos na superfície de corte do rebolo (rebolo mole) haverá o desprendimento dos grãos e, conseqüentemente a renovação das arestas de corte. 
A concentração do rebolo representa a quantidade de abrasivos (em peso) por unidade de volume do rebolo, e também está diretamente relacionada ao seu custo de aquisição e às capabilidades do rendimento (capabilidade da vida do rebolo, remoção de material, taxa de capabilidade, requisitos de potência, acabamento superficial da peça e agressividade). Quando se utilizam valores menores de concentração, os parâmetros de saída (taxa de remoção de material, relação $\mathrm{G}$, acabamento superficial e consumo de energia da máquina) diminuem.

\subsubsection{Ligante do rebolo}

Os ligantes têm a função de manter os grãos aprisionados até que este esteja sem capacidade de corte. Eles determinam a resistência do rebolo, bem como a máxima velocidade de operação da ferramenta. São responsáveis também pelo comportamento elástico ou deflexão dos grãos abrasivos durante o processo.

Os três tipos de ligantes mais comuns atualmente utilizados pelos fabricantes de rebolos, são: resinóides, metálicos e vitrificados (KOPAC \& KRAJNIK, 2006).

\section{a) Ligante Resinóide}

Rebolos com ligante resinóide são obtidos por prensagem à quente de resina fenólica ou poliamida e agente de preenchimento com o tamanho e o peso apropriado do abrasivo. São capazes de altas taxas de remoção, mas possuem baixa capacidade de manter a sua forma e vida-útil (KOPAC \& KRAJNIK, 2006).

As principais características são (BIANCHI et al., 1999).

- Possuem boas qualidades de corte;

- Podem ser utilizados em um grande número de aplicações;

- Podem ser utilizados tanto em retificação refrigerada como a seco;

- Maior ductilidade;

- Estão disponíveis em um grande número de formas e tamanhos.

b) Ligante Metálico

As ligas metálicas compostas de bronze, cobalto, tungstênio ou outros metais são extremamente duras e resistentes ao desgaste. Os ligantes metálicos são obtidos pela sinterização de pós de bronze ou de metal duro, ou pela 
deposição galvânica de níquel sobre um corpo base até que se tenha uma espessura suficiente para fixar os grãos abrasivos (SALMON, 1992). Estas ligas são o tipo mais comum de matriz usada para segurar os cristais superabrasivos.

Nestas ligas os cristais de diamante e CBN devem ser robustos no formato e suaves na textura, para resistir à fratura decorrente do impacto e suportar a degradação térmica causada pelas altas temperaturas geradas no processo de fabricação dos rebolos (CARIUS, 1999).

Estas características tornam extremamente difíceis o desenvolvimento de uma liga suficientemente forte entre 0 cristal e a matriz metálica, conseqüentemente, o principal mecanismo de desgaste de uma liga metálica é a queda de cristais ou a perda de cristais abrasivos, antes de ser completa e efetivamente utilizado.

\section{c) Ligante Vitrificado}

Este tipo de ligante é frágil, extremamente resistente ao desgaste e possui uma boa estabilidade térmica. Outra vantagem significativa da utilização de ligante vitrificado em rebolos de CBN resulta do fato de ele proporcionar boa porosidade e boas propriedades de auto-afiação dos rebolos, o que usualmente simplifica o método do seu condicionamento (SALMON, 1992).

As ligas vitrificadas combinam as características das ligas resinóides e das ligas metálicas. Estas ligas estão sendo largamente usadas nos processos de retificação por apresentarem maior eficiência e melhor acabamento superficial, proporcionando um corte rápido e uma elevada resistência ao desgaste (BIANCHI et al., 1999).

Os níveis de porosidade da matriz nos rebolos de liga vitrificada estão entre $10 \%$ e $25 \%$, comparados aos menos de $2 \%$ da maioria dos rebolos de liga resinóide e de metálica. Esta porosidade abre espaço para a formação de cavaco e para o fluxo do meio refrigerante. Os níveis de porosidade induzida de até $20 \%$ a $30 \%$ são comuns em rebolos vitrificados de CBN.

As principais razões da aceitação do rebolo de CBN com ligante vitrificado são justificadas por (BIANCHI et al., 1999):

- Maior resistência ao desgaste;

- Melhor acabamento obtido;

- Maior durabilidade; 
- Boa capacidade de manutenção da forma geométrica;

- Maior eficiência de retificação;

- Renovam mais fácil os grãos abrasivos;

- Maior força de retenção do cristal;

- Condicionamento mais fácil da superfície devido à porosidade induzida.

No campo dos rebolos de CBN observa-se um crescimento rápido do uso dos ligantes vitrificados na indústria. A empresa GE Company-USA, havia divulgado resultados de um levantamento sobre a utilização dos rebolos superabrasivos nos anos de 1980 e 1997 (BIANCHI et al., 1999). De acordo com os dados apresentados na Tabela 4, pode-se notar uma grande queda na utilização do ligante resinóide (de 76\% para 31\%) e um crescimento intenso (de $4 \%$ para $32 \%$ ) na utilização do ligante vitrificado. Com base nesses números, pode-se verificar que estes dois tipos de rebolos são os mais utilizados e em quantidades praticamente iguais.

Tabela 4 - Evolução de uso dos principais ligantes para rebolos superabrasivos (BIANCHI et al., 1999).

\begin{tabular}{|c|c|c|c|}
\hline Ligante & $\mathbf{1 9 8 0}(\%)$ & $\mathbf{1 9 9 7}(\%)$ & Tendência \\
\hline Resinóide & 76 & 31 & Decrescimento \\
\hline Metálico & 10 & 11 & Crescimento lento \\
\hline Vitrificado & 4 & 32 & Crescimento forte \\
\hline Camadas simples & 10 & 26 & Crescimento forte \\
\hline
\end{tabular}

Segundo os experimentos realizados por Bianchi et al. (1999), o estudo para avaliar o desempenho de rebolos de CBN com os diferentes tipos de ligantes, concluiu que os rebolos fabricados com o ligante vitrificado apresentaram melhores valores da relação $G$, em relação àqueles fabricados com ligante resinóide. 


\subsection{Dressagem de rebolos CBN de liga vitrificada}

Segundo Tönshoff et al. (1992) e Chen et al. (2002), a cinemática do processo de retificação representa uma série de interações irregulares que dependem da microestrutura do rebolo, das quantidades de movimento, bem como dos parâmetros geométricos. Há correlações consideráveis entre a topografia do rebolo, o seu desgaste e as forças geradas. Devido a estas correlações, o processo de retificação é dependente e variável no tempo.

Segundo Chen et al. (2002), na Figura 2.10 os fatores descritos na camada superior são as entradas primárias do processo de retificação e as saídas são listadas na parte inferior. $\mathrm{O}$ ambiente de retificação inclui a atmosfera e o fluido de corte, ambos muito importantes no ponto de vista da lubrificação, e também a estrutura da máquina.

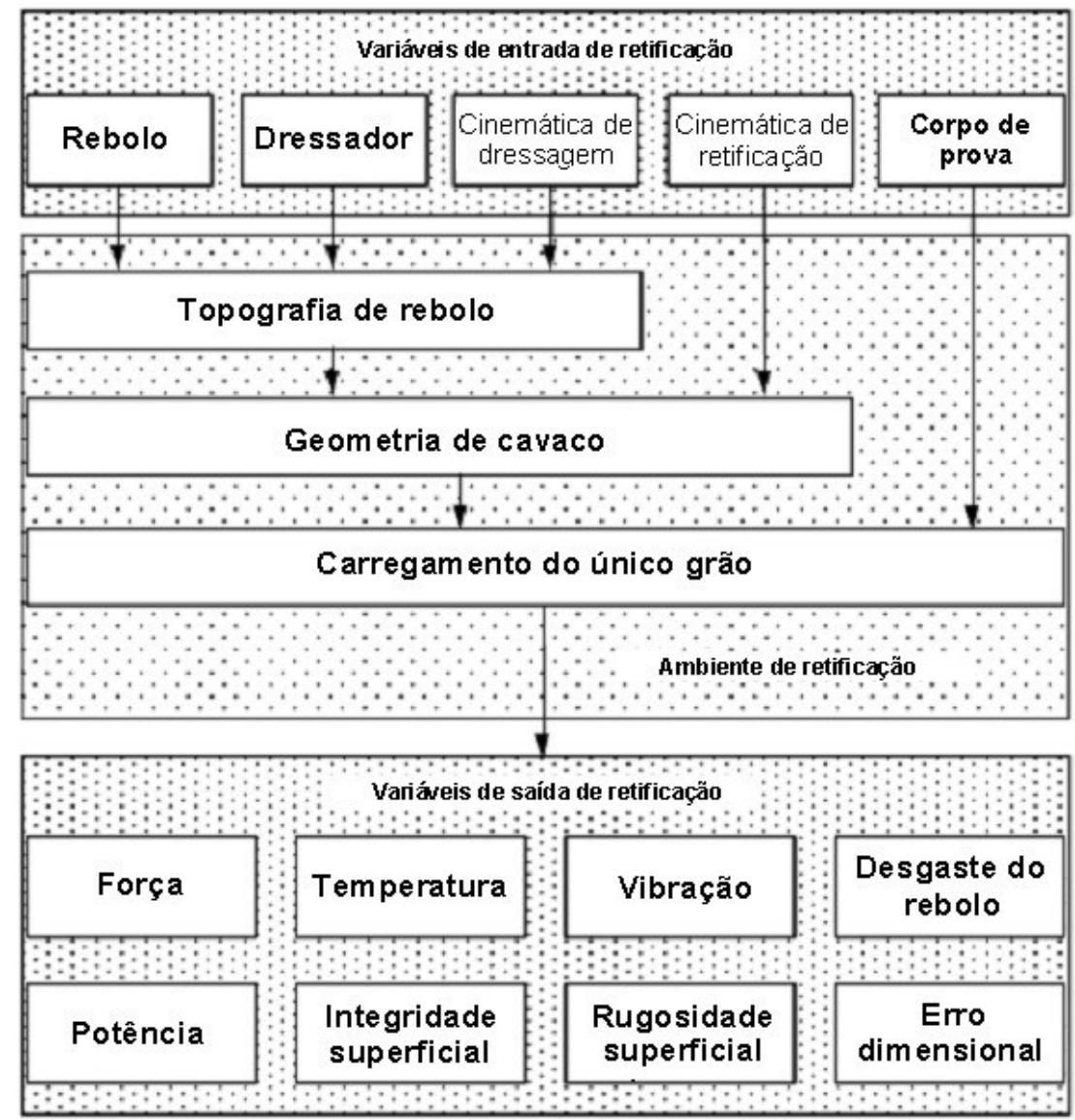

Figura 2.10 - A cinemática de entrada e saída do processo de retificação (CHEN et al., 2002). 
O comportamento do sistema de retificação é analisado primordialmente pelo ponto de vista geométrico, cinemático, mecânico, energético e das propriedades do material. O desempenho rebolo de precisão é geralmente avaliado por grandezas como: força, vibração, temperatura, e rugosidade. $\mathrm{O}$ rebolo corretamente dressado apresenta força e temperaturas baixas, integridade superficial e rugosidade do corpo de provas especificadas, assim como precisão consistente.

O rebolo ao longo de sua utilização sofre desgaste, perdendo sua agressividade, diminuindo a taxa de remoção de material e proporcionando acabamentos grosseiros. A operação de afiação da ferramenta é denominada dressagem. A operação de dressagem tem a finalidade de afiar o rebolo, e para isso a superfície desgastada do rebolo é removida pela passagem de uma ferramenta de diamante, com o rebolo em rotação, cedendo lugar a uma nova camada de grãos abrasivos, restabelecendo assim a capacidade de corte.

Pode-se dizer que a dressagem possui as seguintes finalidades principais (OLIVEIRA, 1988):

- A obtenção de concentricidade da face de trabalho com o eixo de rotação;

- O perfilamento da face de trabalho para uma operação de forma; e

- Fratura ou remoção dos grãos abrasivos gastos para melhorar a agressividade da face de trabalho.

Os dressadores, segundo diversos autores, podem ser divididos de acordo com seu princípio de atuação cinemática em dois grupos principais: dressadores estáticos e dressadores rotativos (OLIVEIRA, 1988; SILVA \& COELHO, 1998).

Enquanto o primeiro grupo não se movimenta na direção da velocidade tangencial do rebolo durante a afiação, as de ponta única e as conglomeradas são dois tipos básicos de ferramenta neste grupo; o segundo, além do movimento de translação, apresenta rotação quando em contato com rebolo, o disco dressador e o rolo dressador são basicamente as duas ferramentas rotativas existentes. A Figura 2.11 mostra alguns tipos de dressadores estáticos e rotativos existentes no mercado. 

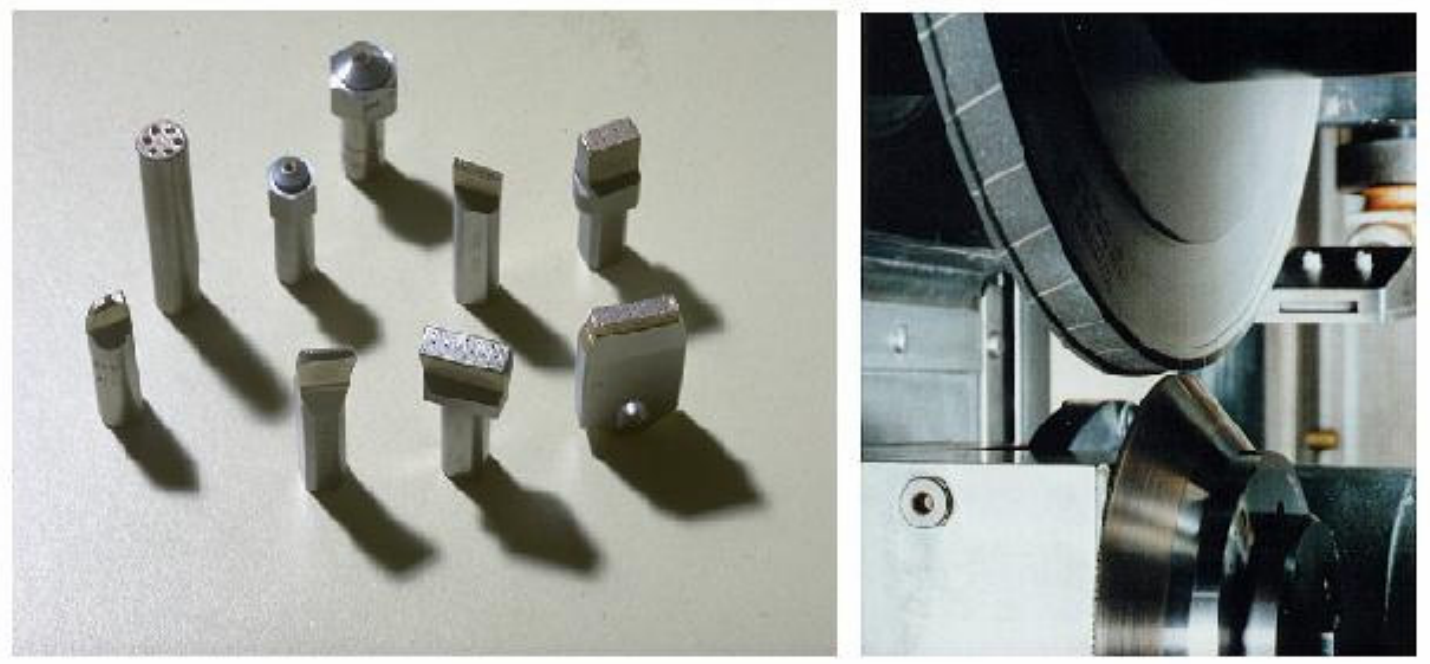

Figura 2.11 - Alguns tipos de dressadores estáticos (esquerda) e rotativo (direita) existentes no mercado (HITCHINER, 2001b).

O momento de dressagem da ferramenta abrasiva surge quando os grãos abrasivos estão excessivamente gasto e o rebolo incapaz de remover material adequadamente, ou também quando o perfil do rebolo está desgastado. Portanto, a dressagem deve ser realizada no momento mais próximo do ponto ideal, pois:

- Se a dressagem for executada antes do ponto de reafiação, tem-se uma perda de tempo e de rebolo, aumento o custo do produto final;

- Se a dressagem for executada após o ponto de reafiação, podem-se produzir peças com queima superficial, trincas, rugosidade fora da especificada, ou erros geométricos, etc.

O estudo de Chen et al. (2002), cita o uso de uma técnica chamada de "dressagem de contato" ou "dressagem de toque" (touch dressing), onde a profundidade de corte (ad) é tão pequena (geralmente menor que $5 \mu \mathrm{m}$ ) que não ocasiona a expulsão do grão (Fig 2.12). Desta forma, o perfil do rebolo é restaurado sem perda de capacidade de corte. 


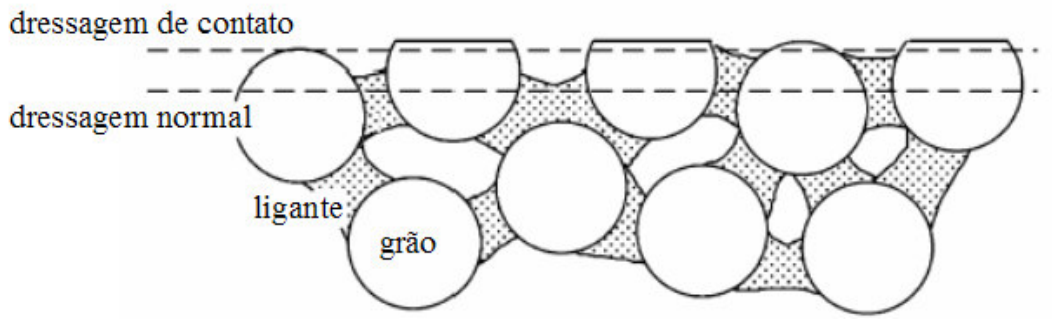

Figura 2.12 - Técnicas de dressagem (CHEN et al., 2002 - Adaptada).

Com o uso desta técnica, a variação da potência de corte durante o processo diminui e faz com que o desempenho da retificação seja mais estável. A variação do valor de rugosidade também diminui durante os ciclos entre uma dressagem e outra. Além disso, esta técnica consome menos rebolo (geralmente um terço a menos do que a técnica convencional), o que reduz os custos do processo (CHEN et al., 2002). A Figura 2.13 demonstra circularidade dos rebolos com diferentes profundidades de dressagem.

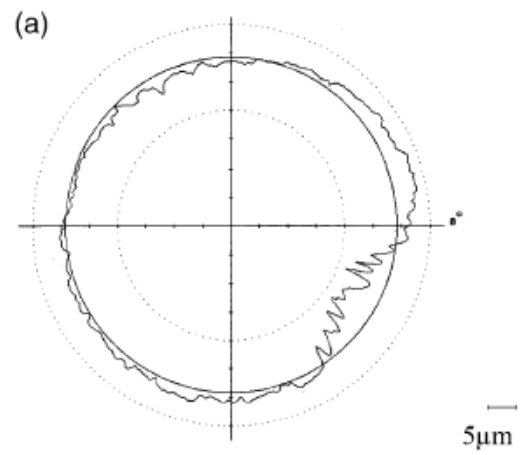

(b)

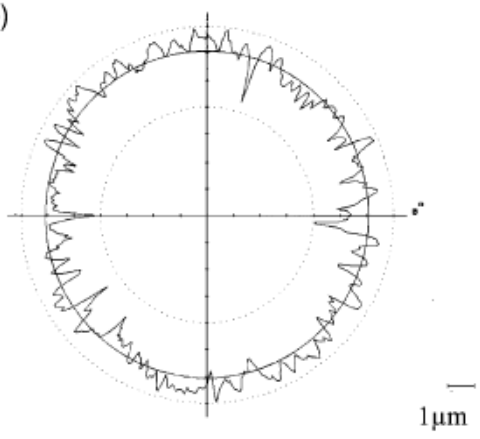

Figura 2.13 - Circularidade dos rebolos com diferentes profundidades de

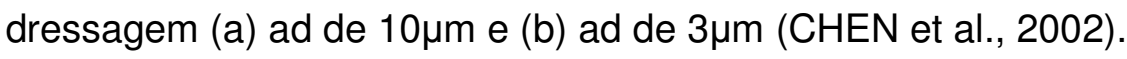

Alguns autores mencionaram a utilização do sinal de emissão acústica para a detecção do contato entre o dressador e o rebolo, já que se deve saber exatamente onde ocorre o contato para não desgastar mais material do que é necessário (OLIVEIRA \& DORNFELD, 2001; HITCHINER, 2001b). A Figura 2.14 mostra o processo de dressagem monitorado pelo sinal de emissão acústica. 

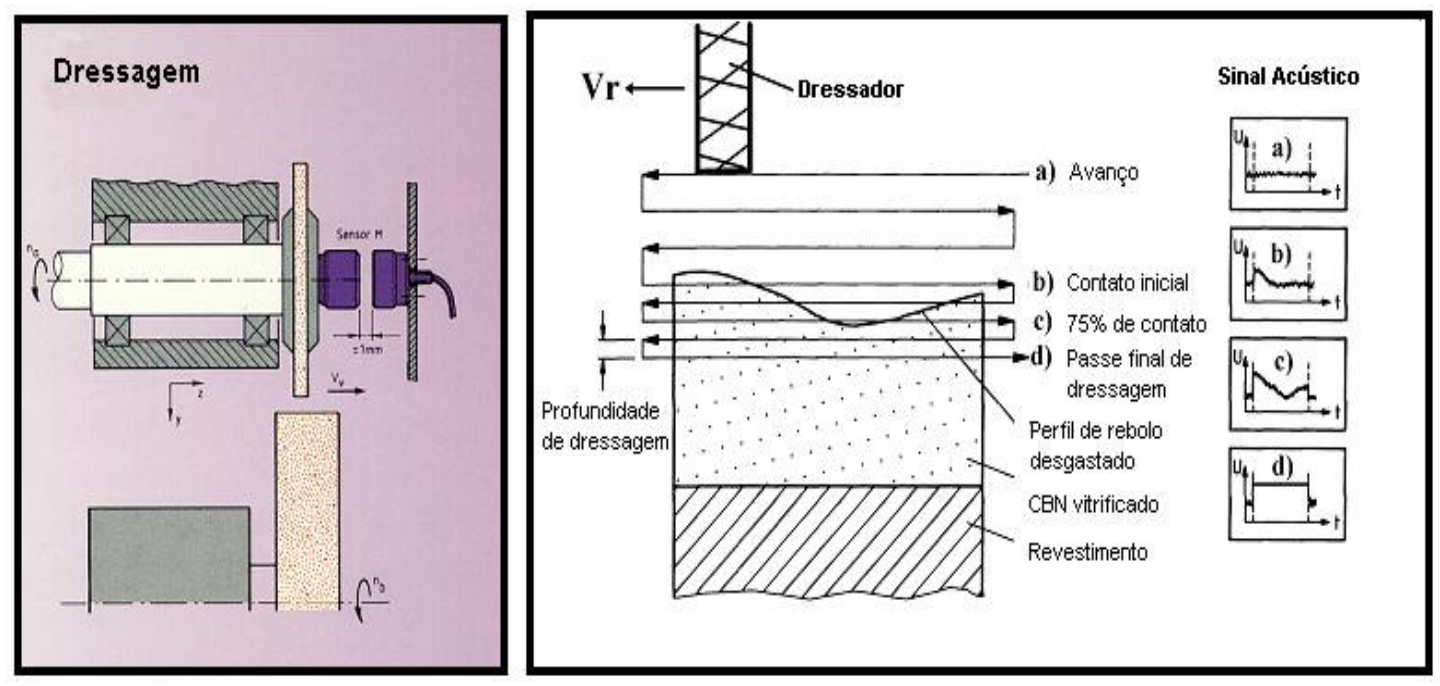

Figura 2.14- O processo de dressagem monitorado pelo sinal de emissão acústica (HITCHINER, 2001b - Adaptada).

Os resultados da retificação são altamente influenciados pelas condições topográficas da superfície de trabalho do rebolo. Um rebolo gasto produzirá muito calor devido ao atrito e às vibrações, que podem prejudicar a resistência e a integridade superficial do produto final. Segundo Silva e Coelho (1998), as forças de retificação num mesmo tipo de operação podem variar até $500 \%$ com a simples mudança das condições de dressagem.

A operação de dressagem para rebolos CBN de liga vitrificada pode ser composta por três etapas: geração de forma, afiação e limpeza (KLOCK \& KÖNIG, 1995). A geração de forma, mais conhecida como truing, permite criar um rebolo com periferia geometricamente corrigida, concêntrica ao seu eixo de rotação, gerando, se necessário, um perfil particular na face de rebolo. A operação de afiação tem como objetivo aumentar a capacidade de corte do rebolo.

Nessas duas operações no caso de rebolos de liga vitrificada acontecem de uma vez só, recebendo simplesmente o nome de dressagem. A operação de limpeza é executada a fim de remover os cavacos que fica alojado nos poros entre os grãos abrasivos de CBN.

O processo de dressagem provoca o corte e a fratura dos grãos abrasivos pelo dressador, além de gerar uma "rosca" na superfície do rebolo, surgem o macroefeito e o microefeito (OLIVEIRA, 1988; SILVA \& COELHO, 1998). 
A formação do macroefeito é função do formato do dressador, da sua profundidade de penetração e do passo de dressagem em que é realizada a operação. Este fenômeno determina a posição em que as arestas dos grãos abrasivos estão localizadas na superfície do rebolo. Pode-se dizer também que o macroefeito corresponde à rosca formada na superfície do rebolo após a passagem do dressador.

O microefeito é causado pela fratura das partículas dos grãos onde novas arestas de corte são criadas pelo dressador. A agressividade das arestas depende da friabilidade do grão e também das condições de dressagem. A Figura 2.15 mostra os efeitos de fratura de diferente profundidade de dressagem.

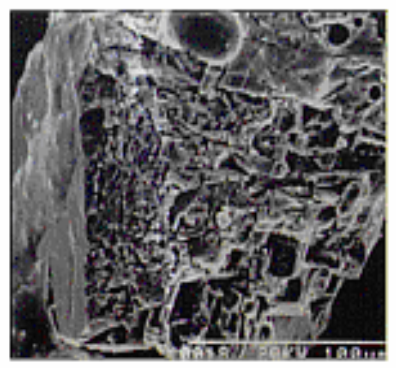

Micro-fratura 1 um

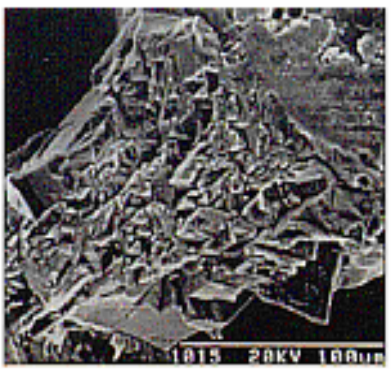

Médio-fratura 2 um

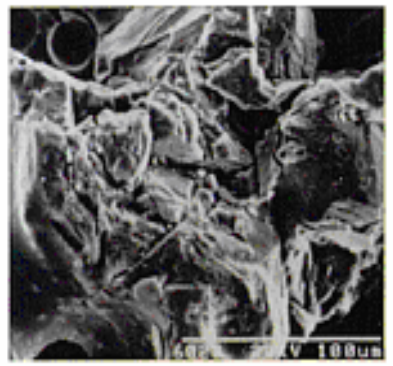

Macro-fratura $3 \mathrm{um}$

Figura 2.15 - Os efeitos de fraturas de diferente profundidade de dressagem (Adaptada HITCHINER, 2001b).

Em função do tipo de configuração adotada entre dressador-rebolo, fatores específicos podem afetar o processo de dressagem e características finais da superfície do rebolo. A Figura 2.16 mostra uma representação esquemática do ponto de contato entre dressador e rebolo numa operação de dressagem com as grandezas envolvidas. 


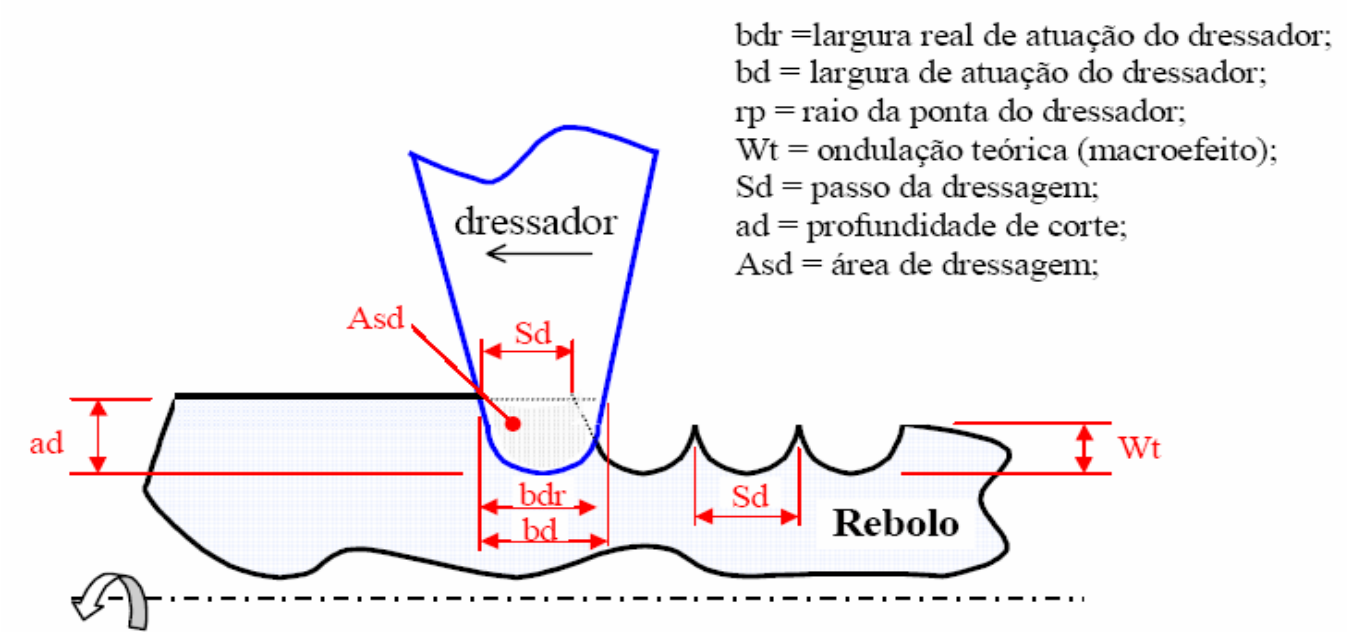

Figura 2.16 - Região de contato entre dressador e rebolo (OLIVEIRA, 1988).

Os parâmetros cinemáticos mais importantes do processo de condicionamento do rebolo são: o grau de recobrimento (Ud), a relação de velocidades entre o dressador e o rebolo (qd) e a profundidade de dressagem (ad).

O grau de recobrimento de dressagem (Ud) é definido como a razão entre a largura de dressagem (bd) e o passo de dressagem (Sd). Este parâmetro procura medir o grau com que a forma do dressador é transferida para a face de atuação do dressador (bd, obtida geometricamente em função da profundidade de dressagem, ad) e o passo de dressagem Sd. A Equação 6 define essa relação.

$$
U_{d}=\frac{b_{d}}{S_{d}}
$$

Este parâmetro é, na realidade, uma tentativa de se definir com maior clareza a interação cinemática entre a ponta do dressador e o rebolo, seu princípio serve tanto no dressador ponta única quanto rotativa.

As condições de dressagem influenciam diretamente na taxa de remoção de material que por sua vez interfere na rugosidade de peça produzida. $\mathrm{Na}$ dressagem grossa, onde o grau de recobrimento é pequeno e o número de arestas atuantes é reduzido, provoca-se um aumento na profundidade dos sulcos que, conseqüentemente, fornece valores mais elevados na rugosidade. $\mathrm{Na}$ 
dressagem fina, com valores maiores de grau de recobrimento, um número significativamente maior de arestas atuantes divide os esforços e cada grão abrasivo penetra menos na peça, reduzindo assim os valores de rugosidade.

Quando se analisa o desempenho do rebolo em faixas mais amplas de grau de recobrimento, principalmente próximo de um, nota-se que a agressividade (capacidade de remoção de material) atinge seu máximo valor para cada profundidade de dressagem (ad). Com maiores profundidades de dressagem a agressividade pode ser aumentada, aumentando-se ainda mais a capacidade de remoção da operação de retificação e a rugosidade superficial da peça. Na Figura 2.17 são apresentadas topografias de rebolos dressados com grau de recobrimento maior, menor e igual a um (OLIVEIRA, 1988).

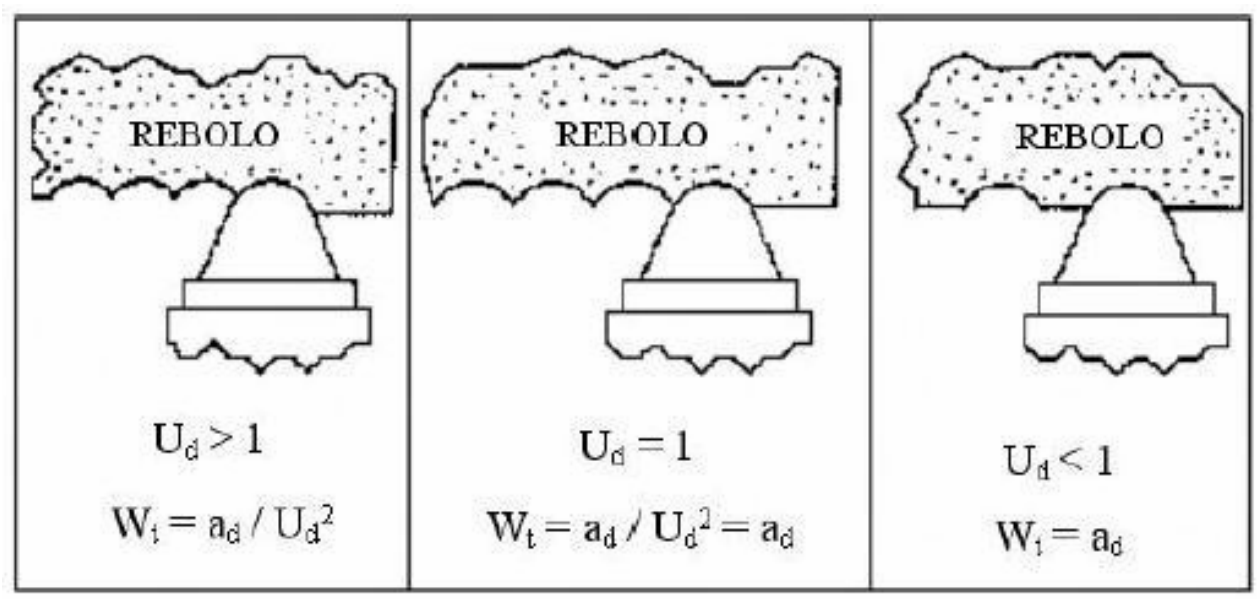

Figura 2.17 - Ação do grau de recobrimento na topografia do rebolo (OLIVEIRA, 1988).

Os valores de Ud próximos a 1,0 (Sd igual bd) produzem as mais altas taxas de remoção de material, onde normalmente a rugosidade superficial não é importante, enquanto que valores de Ud entre 4,0 e 5,0 produzem rugosidade menor. Valores de (Sd) maiores que os de (bd) não devem ser utilizados, uma vez que partes da superfície do rebolo não serão dressadas. Em outra palavra, para garantir que toda a superfície do rebolo seja dressada, o menor valor possível para o (Ud) tem de ser 1,0 (OLIVEIRA, 1988). 


\subsection{Mecanismo de desgaste dos rebolos}

A topografia do rebolo influencia altamente o desempenho do processo de retificação. Diversos fatores podem mudar a sua topografia devido ao desgaste durante o uso. Após um determinado período de retificação, o rebolo deve ser dressado para introduzir novas arestas de corte ao processo e restabelecer sua geometria original.

Malkin (1989) considera que os principais mecanismos de desgaste do rebolo, conforme Figura 2.18 são:

- Desgaste por atrito $(A)$;

- Fratura do grão (B); e

- Fratura do ligante $(\mathrm{C})$.

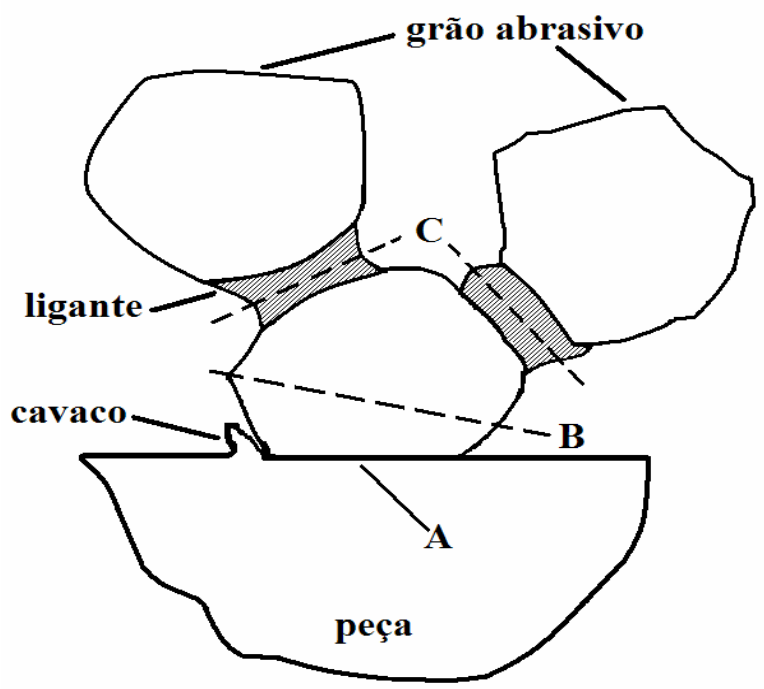

Figura 2.18 - Mecanismos de desgaste (MALKIN, 1989 - Modificada).

O desgaste por atrito gera 0 arredondamento das arestas de corte do grão abrasivo. De acordo com Jackson \& Mills (2004), as causas deste desgaste são:

- Desgaste devido ao atrito entre o material da peça e o grão abrasivo;

- Escoamento plástico do grão abrasivo devido às altas pressões e temperaturas de contato;

- Fraturas e trincas do grão devido à difusão térmica e micro-impactos mecânicos; e 
- Reação química entre grão abrasivo e o material da peça em condições de altas temperaturas e na presença de fluido de corte.

Este tipo de desgaste tem a menor contribuição para redução do volume do rebolo, no entanto, é o fenômeno mais importante para a definição do fim de sua vida. O seu aumento causa uma elevação nas forças de retificação e na temperatura, o que leva a uma diminuição da qualidade e integridade superficial da peça usinada (HASSUI et al., 1998).

Grãos desgastados geram um aumento da área de contato e do atrito entre a peça e o grão. Neste ponto de desgaste do grão abrasivo, altas temperaturas se tornam inerentes ao processo, o que provoca uma forte adesão, e também, reações químicas entre as duas superfícies. Se a fratura do grão ou ligante não ocorrer neste momento, a superfície plana do grão torna-se mais larga e a taxa de desgaste aumenta. Se a fratura persistir em não ocorrer, característica dos rebolos de alta dureza, a faixa do rebolo em contato com a peça se torna de aparência vitrificada e a peça sofre danos térmicos (JACKSON \& MILLS, 2004).

De acordo com Hassui et al. (1998), a fratura do ligante ocorre principalmente em rebolos com ligante vitrificado e é o que mais influencia na perda de volume do rebolo.

Além de os mecanismos de desgaste mencionados por Malkin (1989), os autores Jackson \& Mills (2004) ainda classificam um quarto mecanismo de desgaste chamado de fratura da interface grão-ligante. A Figura 2.19 mostra diversos mecanismos de desgaste do rebolo, onde: I - mostra um grão abrasivo de superfície desgastada (A); II - apresenta uma fratura de ligante com grão abrasivo (A), interface grão-ligante $(B)$ e ligante (C); III - exibe um grão fraturado (A); e IV - apresenta uma fratura da interface grão-ligante. 

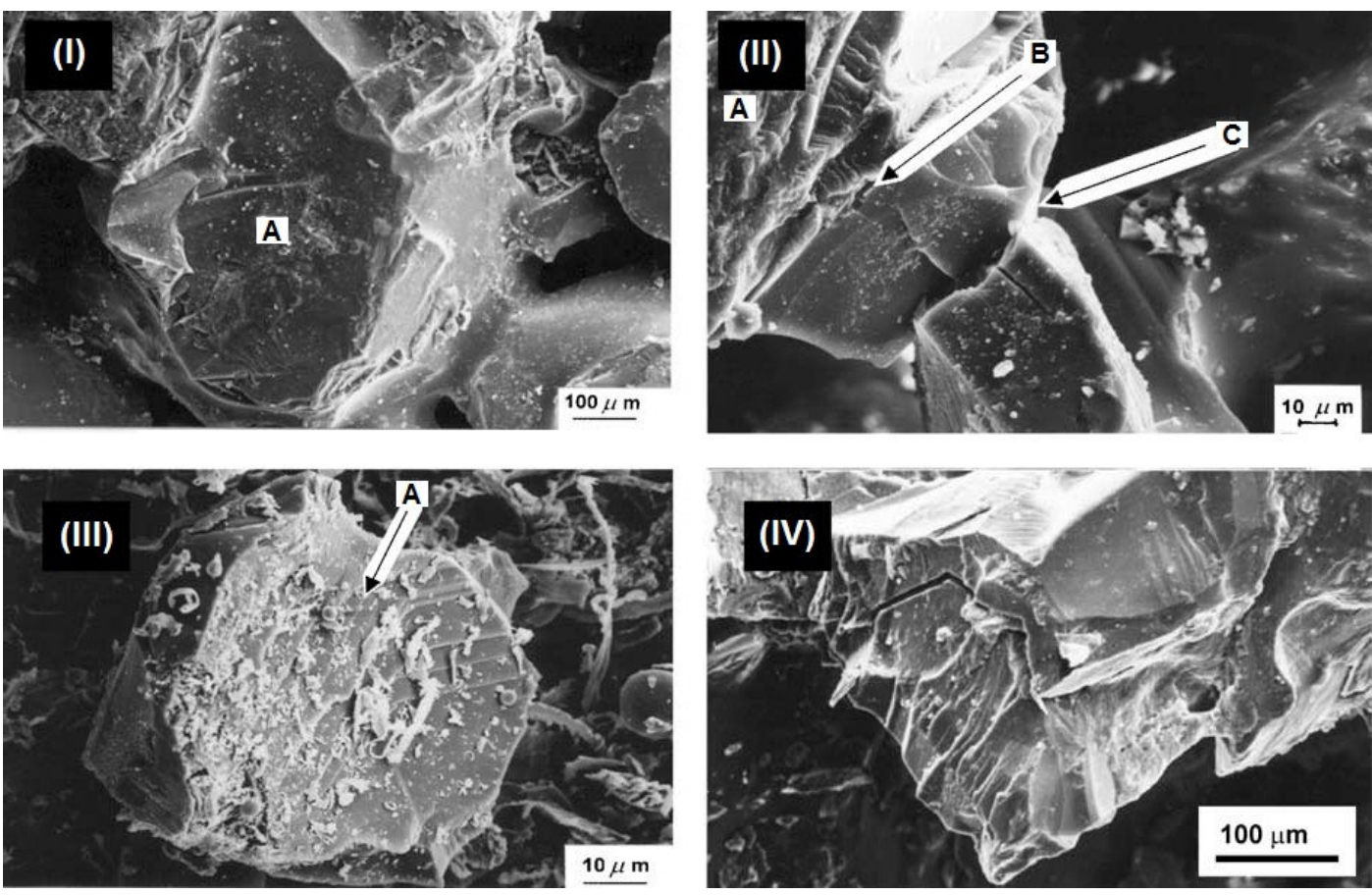

Figura 2.19 - Mecanismos de desgaste (JACKSON \& MILLS, 2004).

O desgaste total pode ser expresso em termos da relação $G$, que é a taxa volumétrica de material removido em contraposição ao desgaste volumétrico de rebolo. Na retificação com rebolos convencionais, o rebolo pode ser mais consumido pela dressagem do que pelo processo de retificação em si.

Segundo Malkin (1989), as restrições de desgaste do rebolo são freqüentemente associadas à rugosidade e às tolerâncias necessárias. Com taxas de remoção mais elevadas, a relação $G$ tende a diminuir, levando uma diminuição da qualidade de superfície acabada. A escolha de um fluido de corte adequado pode oferecer grande relação $\mathrm{G}$, diminuir temperatura e forças de usinagem.

\subsection{Monitoramento por Emissão Acústica (EA)}

O processo de retificação não pode ser observado satisfatoriamente devido à baixa visibilidade causada pelo fluido refrigerante e, em algumas situações, pelo fato da máquina ser fechada. Os sistemas de monitoração do processo, portanto, tornaram-se essenciais para as retificadoras. 
A aplicação da emissão acústica na retificação é estudada desde a década de 80. Em pesquisa realizada por Oliveira \& Dornfeld (2001), determinou-se um eficiente método para detecção de contato entre o rebolo e a peça ou entre o rebolo e o dressador através do valor da raiz média quadrática da emissão acústica.

O objetivo de monitoramento é garantir a confiabilidade do processo. As mensagens de erro provindas dos sensores podem ser usadas como entrada para diagnóstico, de forma que o motivo e o erro sejam encontrados e localizados. Nos campos de processo de produção, as principais aplicações destes sistemas são (TÖNSHOFF et al., 2000):

- Controle e localização do defeito dos componentes de máquina;

- Reconhecimento de falhas durante a usinagem;

- Reconhecimento de imprecisão da máquina, que conduz à falha na qualidade;

- Auxílio no funcionamento e manutenção de máquinas e componentes.

Os sensores para monitoramento em processo desempenham um importante papel de auxílio aos sistemas de manufatura. Estes são usados para monitoramento e controle dos processos (DORNFELD, 1999).

Os sensores para o monitoramento do processo devem atingir os seguintes requisitos (BYRNE et al., 1995):

- A medição deve ocorrer o mais próximo possível da máquina;

- Não deve haver redução na rigidez estática e dinâmica da ferramenta;

- Não deve haver restrição de espaço útil de usinagem e dos parâmetros de corte;

- Livres de desgaste e de manutenção, ser facilmente trocados e possuir um baixo custo;

- Resistentes à sujeira, cavacos e interferências mecânicas, eletromagnéticas e térmicas;

- Funcionar independentemente da ferramenta e da peça;

- Adequar-se às características metrológicas;

- Transmitir o sinal de forma confiável. 
De acordo com Lee et al. (2006), os diferentes sensores têm aplicações distintas em variados níveis de precisão e taxa de remoção de materiais. Os autores apresentam um diagrama esquemático dos diversos tipos de sensores para variados níveis de precisão, como mostra a Figura 2.20. A linha tracejada representa a faixa aproximada de utilização e a área sombreada enfatiza a faixa de aplicação mais importante.

A emissão acústica, como está ilustrada, mostra a maior sensibilidade (com o nível de ruído mais baixo, isto é, a relação mais alta sinal/ruído) para as condições mais críticas de processo na usinagem de precisão.

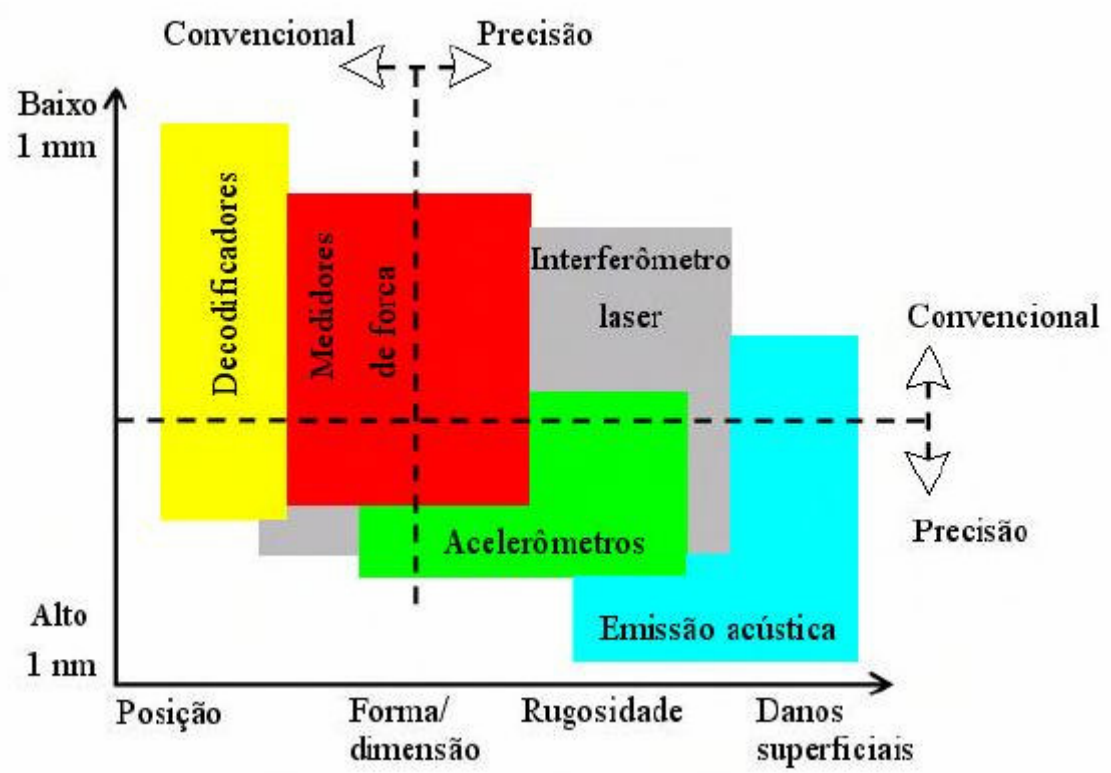

Figura 2.20 - Aplicação de sensores comparado com o nível de precisão e parâmetro de controle de erros (LEE et al., 2006 - Adaptada).

Entretanto, sensores como os de emissão acústica apresentam melhor resposta na faixa de alta freqüência, onde grande parte dos sinais de distúrbios de baixa freqüência induzidas pela máquina são reduzidos e as freqüências da atividade de usinagem de precisão no nível submicron tornam-se predominantes (DORNFELD, 1999).

A Emissão Acústica (EA) pode ser definida como ondas transientes de tensão geradas pela repentina liberação de energia de deformação ou pela liberação de energia de atrito, de uma ou várias fontes localizadas numa estrutura. 
As principais fontes de emissão acústica devem ser consideradas no processo de retificação, tais como: impacto elástico, riscamento sem remoção de cavaco, remoção de cavaco, quebra de cavaco, fratura de grão, fratura da ligação entre grãos, rachaduras e indução térmica de mudanças estruturais, como mostrados na Figura 2.21 (KARPUSCHEWISKI, 2001).

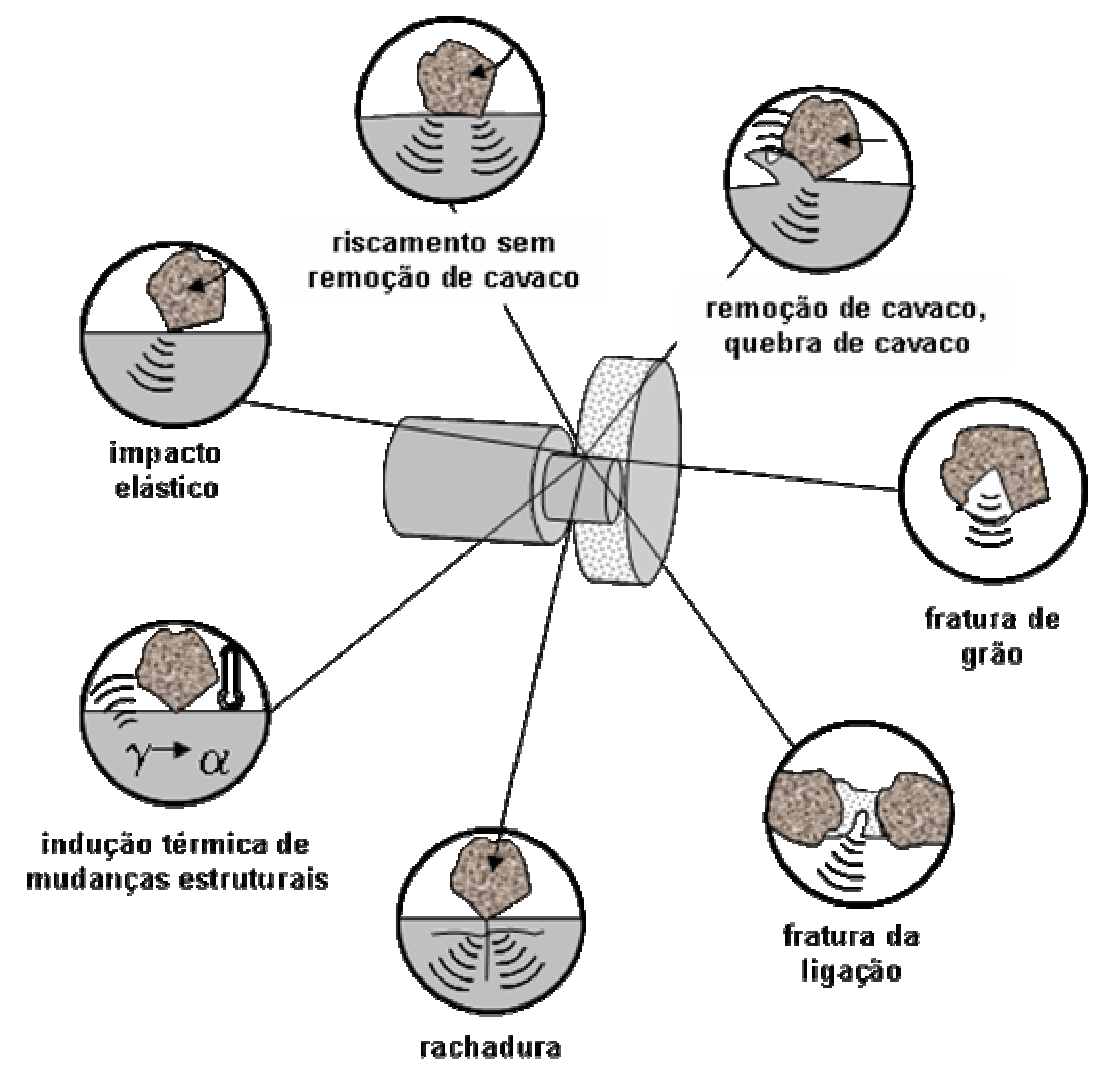

Figura 2.21 - Fontes de emissão acústica em retificação (KARPUSCHEWISKI, 2001).

Sinais dos sensores de emissão acústica podem ser usados para identificar mudanças nas condições operacionais do rebolo e, em conjunto com uma análise de densidade do espectro de potência, detectar trepidação e vibração danosas ao processo. (VARGHESE et al., 2000). Defeitos de circularidade do rebolo poderão ser detectados a partir de variações nos sinais de emissão acústica, captados durante operação de dressagem do rebolo. Entretanto, a acentuação do sinal acústico longe da fonte e grande quantidade de fluxo de dados são fatores que poderão limitar a utilização dos sensores de emissão acústica nestas aplicações. 
Existem várias grandezas relacionadas ao processo de retificação que podem ser monitoradas em processo para o acompanhamento e controle. $\mathrm{Na}$ Figura 2.22, Oliveira \& Dornfeld (2001) mostram alguns problemas de retificação, os tipos de sensores aplicáveis, o status de seu desenvolvimento e de sua implantação industrial. Na maioria dos casos apresentados, os problemas podem ser solucionados através da aquisição dos sinais de EA do processo, através de hardwares especiais e computadores de última geração.

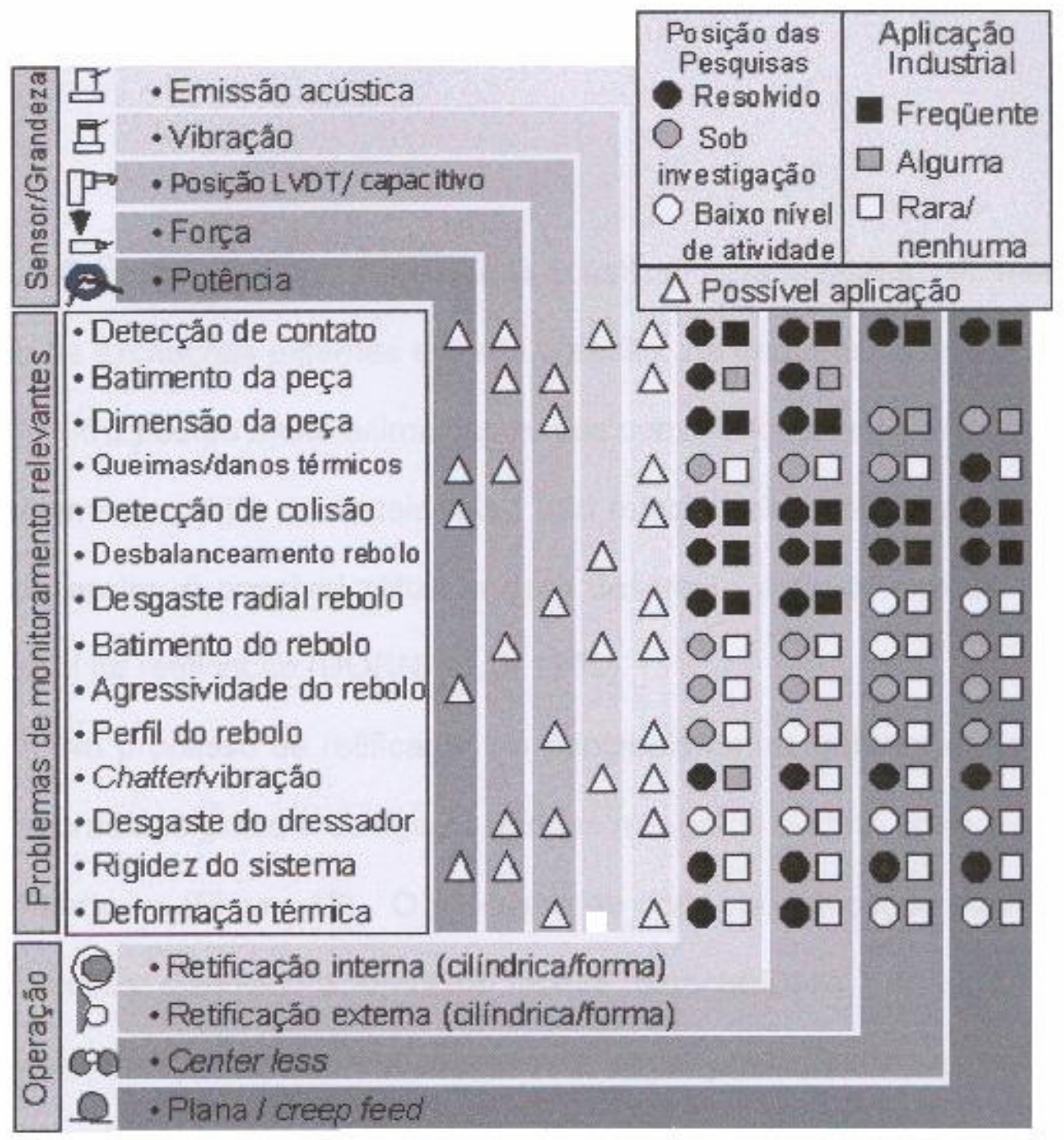

Figura 2.22 - Problemas na retificação (OLIVEIRA \& DORNFELD, 2001).

As investigações experimentais de Brinksmeier et al. (2005) utilizaram o sistema de EA em um ciclo de retificação de três etapas (Figura 2.23). Pode-se ver que as etapas de retificação grossa e fina podem ser distinguidas claramente 
pelo sensor de força integrado ao rebolo, bem como pelo piezo-dinamômetro convencional. A respeito do sinal $A E$, pode-se observar um aumento no final da operação de acabamento e durante o spark-out, que é causado pela vibração da retificação. Pelo sensor da força integrado ao rebolo uma amplitude mais elevada do sinal foi registrada ao mesmo tempo, quando este efeito não pôde ser visto no sinal da força estática.

Sensor de força integrado no rebolo:

Dinamômetro abaixo de eixo do motor:

Sinal de emissão acústico:

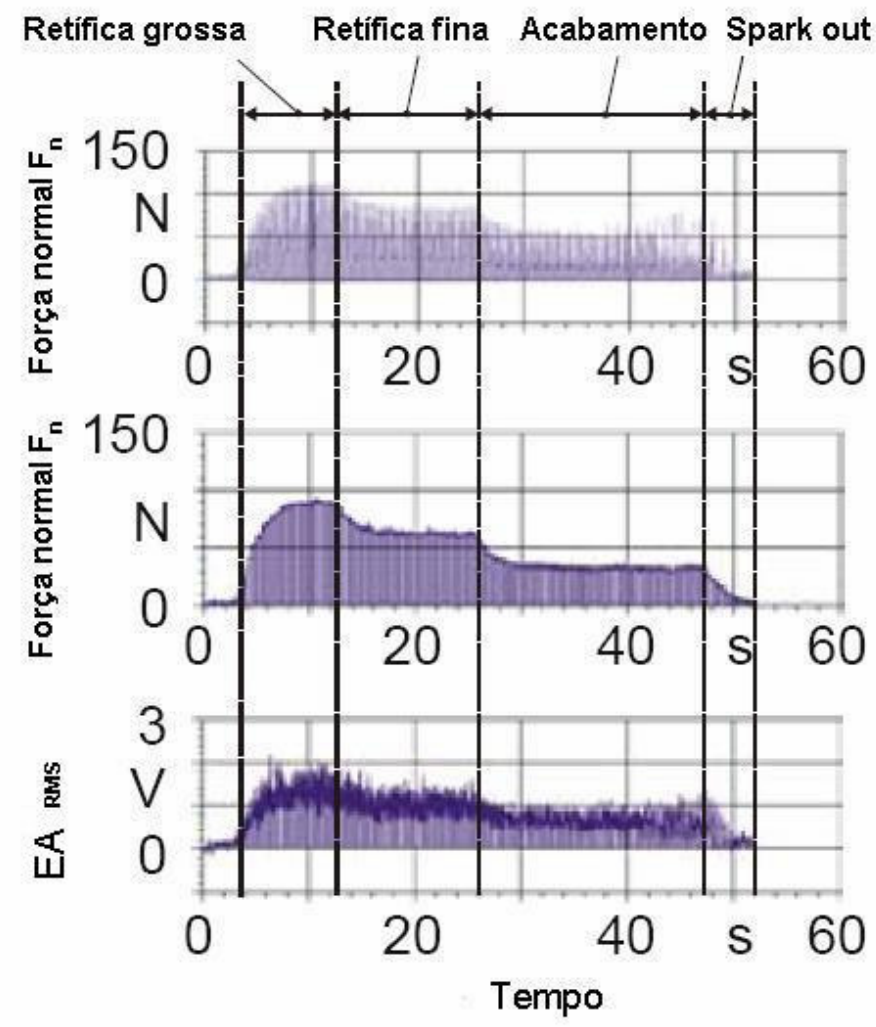

Figura 2.23 - Comparação de forças de retificação e sinal AE (BRINKSMEIER et al., 2005).

\subsubsection{Sistema de mapeamento acústico}

Oliveira \& Dornfeld (2001) propuseram um sistema inovador para processamento e análise de sinal acústico do processo de retificação. Este método é baseado na analise do sinal RMS (root mean square) da emissão acústica (EA) em intervalos temporais bastante curtos. A emissão acústica obtida 
pelo contato entre dressador e rebolo (ou entre rebolo e peça, no caso de outro tipo de medição) é convertida para RMS (root mean square) e adquirida através de um computador, utilizando-se uma placa de aquisição com conversão de sinais analógica para digital.

A imagem é construída através de representação do nível EA para cada amostra adquirida, utilizando-se um gráfico tridimensional com escala de cores. Durante a operação de dressagem uma imagem é construída em tempo real, através da adição de colunas nos vetores, como se o dressador avançasse ao longo da superfície do rebolo. A Figura 2.24 explica esquematicamente como a imagem é formada.

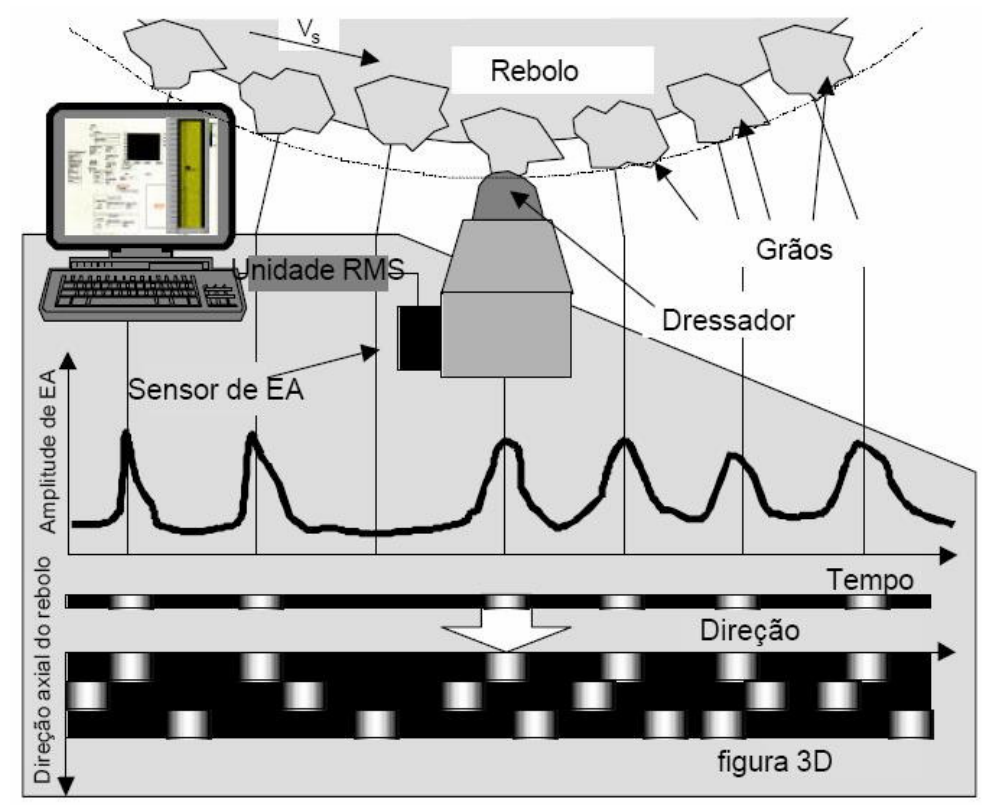

Figura 2.24 - Procedimento da construção do mapa acústico (OLIVEIRA \& DORNFELD, 2001).

O sistema pode ser utilizado para três diferentes avaliações:

- Avaliação da dressagem: Durante a operação de dressagem, a interação dressador-rebolo pode ser acusticamente mapeada. A ausência de contado entre dressador e grão abrasivo é representada por uma área escura no mapa.

- Mapeamento topográfico: Neste caso, o mapa obtido é similar aquele para a operação de dressagem, todavia, utiliza-se uma profundidade de dressagem próxima à zero ou com valor próximo aquele da espessura do cavaco não-deformado para a operação. Desta forma, o 
mapa apresenta a superfície ativa do rebolo, a qual efetivamente entrará em contato com a peça durante operação de usinagem.

- Avaliação da retificação: Durante a operação de retificação de mergulho, a interação rebolo-peça pode ser avaliada. Neste caso, um mapa diferente é obtido, onde um dos eixos representa o tempo de retificação e o outro mostra a energia acústica média em todo seu comprimento, através de seu perímetro.

A Figura 2.25 mostra o gráfico de saída do sistema de mapeamento acústico quando este é utilizado numa operação de dressagem. As direções verticais e horizontais são o comprimento circunferencial do rebolo e a sua largura, respectivamente. A intensidade de cores mostra os valores de emissão acústica RMS medidos através da interação entre o dressador e os grãos abrasivos. As áreas mais escuras representam a menor energia acústica detectada pelo sensor. A marca em formato $L$ foi criada na superfície do rebolo a fim de checar a profundidade do sistema. A faixa escura presente no lado esquerdo do rebolo foi causada por uma operação de retificação utilizando apenas esta área do rebolo (OLIVEIRA \& DORNFELD, 2001; LEE et al., 2006). 


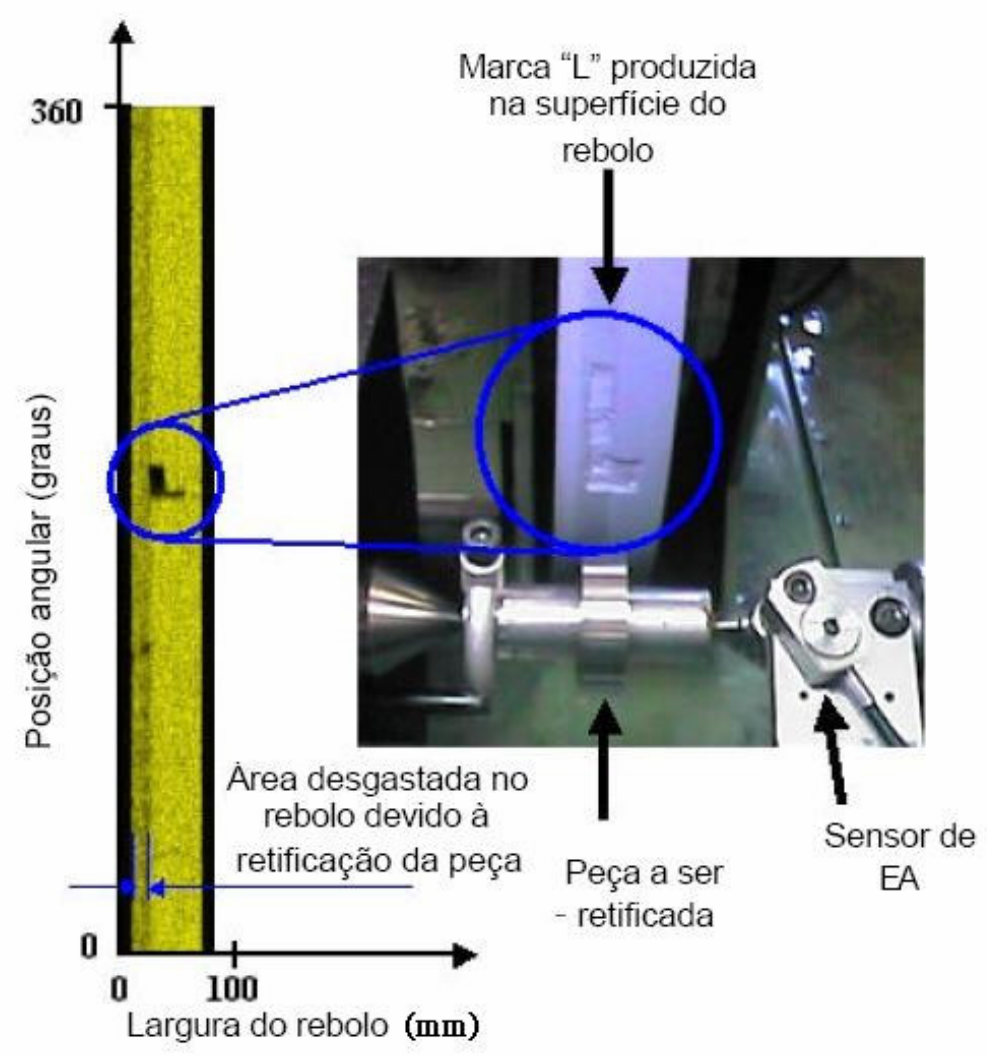

Figura 2.25 - A marca $L$ produzido na superfície do rebolo corresponde a mapa EA durante a dressagem (LEE et al., 2006).

Os mapas de Emissão Acústica são capazes de identificar o desgaste de rebolo, como mostra a Figura 2.26 (OLIVEIRA \& DORNFELD, 2001). O mapa foi apresentado em duas operações de retificação diferentes. A imagem composta de várias partes mostra dois comportamentos de desgaste do rebolo distintos. No primeiro experimento, a manutenção do padrão gráfico em torno do rebolo mostra que este não está perdendo grão. No segundo, as transformações na imagem indicam que o rebolo está soltando grão. 


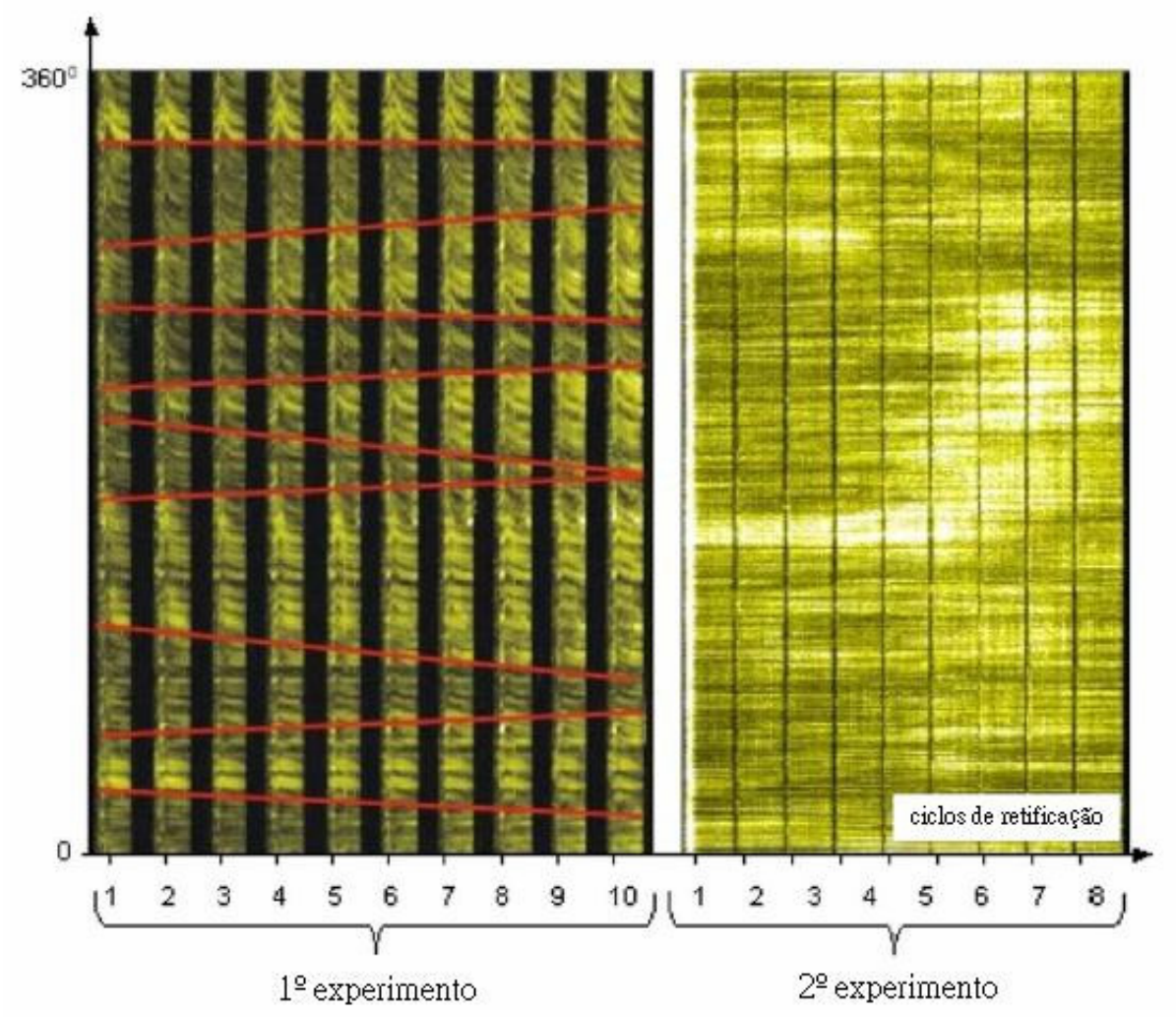

Figura 2.26 - Mapa obtido em duas operações distintas durante a operação de retificação (LEE et al., 2006).

A análise do padrão obtido pode ser diretamente relacionada com algumas anomalias de retificação, sendo que algumas delas já foram testadas e são descritas a seguir (OLIVEIRA \& DORNDELD, 2001).

- Rebolo desbalanceado: O padrão mostra faixas escuras horizontais com resultado de uma baixa interação do rebolo em posição angulares de menor massa;

- Vibrações na retificação: apresentam-se padrões horizontais quando o rebolo torna-se ondulado. Apresenta padrões inclinados quando não existe sincronismo entre o rebolo e o fenômeno causador da vibração;

- Rebolo de arraste excêntrico (para retificação centerless): o padrão obtido mostra inúmeras faixas verticais representando a ausência de contato entre $o$ rebolo e a peça. A distância entre as faixas corresponde a uma revolução do rebolo de arraste.

O mapeamento acústico é uma técnica eficaz a ser utilizada em inúmeras outras aplicações de retificação. Esta ferramenta é confiável uma vez que o nível 
de EA RMS não é a característica principal, mas sim o padrão obtido em torno do rebolo, sendo este último a base de monitoramento. A Figura 2.27 apresenta um exemplo de mapa acústico obtido no processo de retificação com vibrações (à direita).

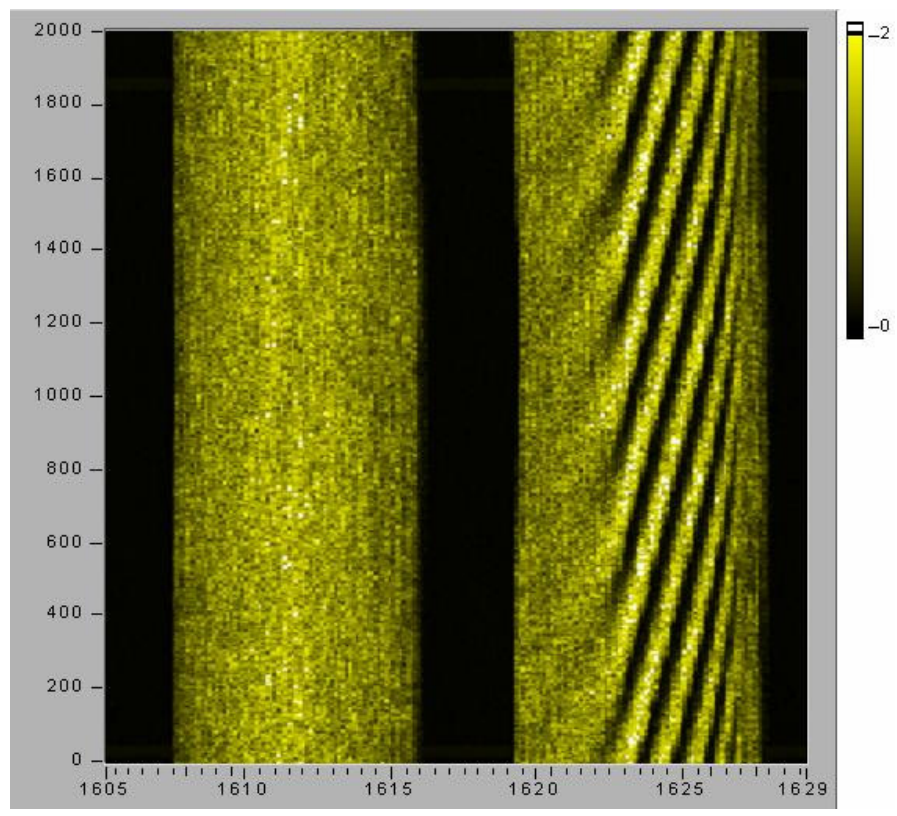

Figura 2.27 - Exemplo de mapa acústico obtido no processo de retificação com vibrações (à direita).

\subsection{Fluido de retificação}

O processo de retificação é acompanhado por um elevado consumo de energia durante as etapas de formação do cavaco. Grande parte desta energia é convertida em calor, o que acarreta em elevadas temperaturas na região de corte, resultando em uma solicitação térmica da peça que pode levar ao comprometimento da integridade da superfície retificada. Desta forma, a aplicação de fluido nos processos de retificação é muito importante, pois, são requeridas taxas de remoção cada vez mais elevadas, alta qualidade e vida do rebolo mais longa.

A escolha do melhor tipo de fluido e de um modo eficiente de aplicá-lo são dois aspectos significativos para alcançar objetivos de produtividade e podem ser 
tão importantes quanto as especificações do rebolo. Uma boa aplicação de fluido reduzirá a incidência da queima pela redução de energia específica e diminuindo as temperaturas da zona de contato (WEBSTER et. al, 1995).

As principais propriedades de um fluido de corte no processo de retificação são:

- Refrigeração: Tem como finalidade remover o calor gerado na operação de forma mais eficiente, evitando o desgaste prematuro do abrasivo e alterações nas propriedades da peça.

- Lubrificação: Boa lubrificação significa a redução do atrito entre a peça e a ferramenta abrasiva, e desta forma, reduzir o calor gerado. Como conseqüências: melhor acabamento, maiores velocidades de corte e maior produção.

- Lavagem: A função da lavagem é remover da área de corte da ferramenta abrasiva os resíduos provenientes do processo de retificação, evitando desta forma um "empastamento" no rebolo.

A consciência ambiental, que cresce consideravelmente a cada ano, e o aumento dos problemas de descartes pressionado por uma legislação mais severa, obriga que mais indústrias se aprofundem nas questões de compatibilidade ambiental das suas fábricas.

Ao mesmo tempo surgem novos conceitos, como a usinagem com mínima quantidade de fluido de corte, também chamada de mínima quantidade de lubrificação (MQL), uma vez que esses fluidos representam grande parcela do custo final da peça, como conseqüência de gastos com a manutenção e descarte. Um dos principais fatores que influenciam no estado final da peça usinada, além das condições de usinagem, é a forma e a quantidade de aplicação dos fluidos de corte no processo. Isto fica ainda mais evidente quando se questionam os custos com os fluidos de corte no setor industrial, podendo chegar a $17 \%$ dos custos de produção (MACHADO \& DINIZ, 2000).

Os fluidos de óleo puro (integral) são usados na maioria dos países europeus por causa de seu melhor desempenho na retificação mais severa e o melhor acabamento de superfície. Entretanto, nos EUA, estes fluidos estão sendo substituídos em favor do fluido à base de água por causa de preocupações ambientais. Um problema adicional com óleos puros é o risco de fogo, 
especialmente na retificação de superligas com elevado centelhamento (sparking), conforme a utilização de alta velocidade de rebolo e maiores pressões de fluidos (WEBSTER et. al, 1995).

A seleção do tipo mais adequado de fluido de corte e sua forma mais eficaz de aplicação com a utilização de rebolos de CBN na retificação de alta velocidade estão sendo pesquisadas (WEBSTER et. al, 1995).

A grande quantidade de calor produzida na retificação pode levar a consideráveis solicitações térmicas no rebolo e na peça. No lado do rebolo, com a falta de uma refrigeração adequada, pode-se esperar um desgaste mais acentuado. No lado da peça, podem ser produzidos problemas como alterações de dureza, deformações, trincas, áreas queimadas e manchadas. Além disso, os cavacos formados são relativamente pequenos, para que se mantenha a capacidade de corte do rebolo, os poros não devem estar empastados. Deste modo, quase sempre são empregados fluidos de corte na retificação.

As principais funções dos fluidos de cortes são lubrificação e refrigeração, mas também outras funções podem ser oferecidas pelos fluidos, tais como (ALVES, 2005):

- Proteção contra corrosão;

- Redução da dilatação térmica da peça;

- Redução no custo de ferramental na operação;

- Retirada do cavaco da região de corte;

- Prevenção contra soldagem cavaco-ferramenta (formação de arestas postiças);

- Evitar dano à estrutura superficial e o crescimento exagerado de tensões residuais na superfície da peça usinada.

\subsubsection{Classificação dos fluidos de corte}

Um fluido de corte pode ser predominantemente um refrigerante e/ou um lubrificante. Dependendo do tipo de usinagem um efeito é mais importante de que outro. No caso de usinagem com velocidade de corte elevada o efeito refrigerante é mais importante, por outro lado, em operações como furação, rosqueamento ou brochamento a característica lubrificante é a mais importante bem como o 
transporte dos cavacos. Existem situações onde a utilização de fluidos de corte é indesejável, por exemplo, em operações de fresamento onde o corte é interrompido, o fluido refrigerante pode causar fatiga térmica.

Os fluidos de corte podem ser agrupados em dois tipos básicos (HOWES, 1990; SALMON, 1992; ALVES, 2005; NOVASKI \& RIOS, 2004; MACHADO \& DINIZ, 2000):

> Óleos de corte (integral ou aditivado);

$>$ Fluidos de corte a base de água:

- emulsionáveis convencionais;

- emulsionáveis semi-sintéticos;

- soluções (fluidos sintéticos).

Os óleos de corte são, basicamente, óleos minerais puros ou com aditivos, normalmente de alta pressão e geralmente de base parafínica. Em relação aos fluidos de corte à base de água, os óleos possuem maior viscosidade e excelentes propriedades lubrificantes, bom controle anti-ferrugem, longa vida útil, porém, apresentam menor poder refrigerante quando comparando com os fluidos de corte a base de água.

O emprego destes óleos como fluido de corte nos últimos anos tem perdido espaço para os óleos solúveis em água, devido ao alto custo em relação aos demais, aos riscos de fogo, ineficiência a alta velocidade de corte, baixo poder refrigerante e formação de fumos, além de oferecerem riscos à saúde do operador.

Os fluidos de corte a base de água são misturas que variam entre emulsões e soluções dependendo da constituição básica do concentrado (óleo mineral ou sais orgânicos e inorgânicos, respectivamente), da presença e da quantidade de emulgadores no mesmo. Em todos os casos, a água atua exclusivamente como agente refrigerante com grandes vantagens: fácil disponibilidade, baixo preço, baixa viscosidade, atóxica e não-inflamável.

Esses fluidos fornecem uma significativa capacidade de refrigeração acompanhada de uma moderada lubrificação, características de grande importância que são requeridas pelas operações que se processam em alta velocidade e baixas pressões.

As emulsões geralmente são leitosos na aparência e compostos bifásicos de óleos minerais adicionados à água na proporção de $1: 10$ a 1:100, mais 
agentes emulgadores que garantem a miscibilidade com a água. Apresentam menor poder lubrificante e maior poder refrigerante que o óleo integral. Todavia necessitam de cuidados especiais, para evitar os efeitos nocivos da água presente na emulsão empregam-se aditivos anticorrosivos e são usados ainda biocidas, que inibem o crescimento de bactérias e fungos.

Os óleos semi-sintéticos são combinações de fluidos sintéticos e emulsões em água. Estes fluidos são compostos de fluidos sintéticos que contém somente uma pequena porcentagem de óleo mineral emulsionável, variando de 5 a $30 \%$ do total do fluido concentrado. A menor quantidade de óleo mineral e a presença de biocidas aumentam a vida do fluido de corte e reduzem os riscos de saúde.

Os fluidos sintéticos baseiam-se em substâncias químicas que formam uma solução com água. Consistem de sais orgânicos e inorgânicos, aditivos de lubricidade, biocidas, inibidores de corrosão entre outros, que são adicionados à água e não contém óleo mineral em sua composição. Apresentam uma vida maior por serem menos atacados por bactérias e reduzem o número de troca de fluido da máquina. Possuem rápida dissipação de calor, excelente poder detergente e visibilidade da região de corte, facilidade no preparo da solução, elevada resistência à oxidação do fluido e à ferrugem. $O$ baixo poder lubrificante, a formação de compostos insolúveis e de espuma para determinadas operações de usinagem podem ser algumas desvantagens na utilização deste tipo de fluido.

Segundo Leal (1993) apud Alves (2005), os óleos integrais eliminam a decomposição do $\mathrm{CBN}$, associada à formação de vapor a alta temperatura e a oxidação, e também, diminuindo o calor gerado pela fricção do rebolo sobre a peça. Esta pode ser uma explicação para o melhor desempenho dos rebolos de CBN com fluido integral.

A eficácia de um fluido de corte depende de fatores como posicionamento do bico, velocidade de aplicação, vazão de fluido e projeto do bocal. Outro problema da aplicação de fluido refrigerante é a barreira aerodinâmica gerada pela elevada rotação do rebolo no processo.

De acordo com Webster et al. (1995), a aplicação do fluido a base de água em velocidades elevadas é muito difícil comparada aos óleos puros porque sua baixa viscosidade promove um jato disperso ao se usar bocais com desenho 
convencional, além de requerer que o operador posicione o bocal o mais perto possível do arco de retificação para minimizar a dispersão.

Um projeto inadequado do bico de aplicação de fluido e das tubulações leva à dispersão do jato de fluido durante a tentativa de aumentar a sua velocidade de saída. O desempenho dos fluidos de corte será aumentado se todo o sistema de aplicação (bomba, projeto de bico e tubulações) for otimizado (WEBSTER et al. ,1995).

\subsection{Retificação de superligas a base de níquel}

O termo superligas foi introduzido pela primeira vez após a Segunda Guerra Mundial, para descrever um grupo de materiais que foram desenvolvidos para serem utilizados em turbinas de aeronaves que necessitavam de alto desempenho em elevadas temperaturas. As superligas, portanto, são definidas como um grupo de materiais que foram projetados para funcionar por longo período de tempo, em atmosferas altamente oxidantes e corrosivas, submetidas a temperaturas acima de $540 \stackrel{\circ}{ } \mathrm{C}$, mantendo suas ótimas propriedades mecânicas. (SIMS et al., 1987).

As superligas são conhecidas como materiais de difícil usinagem. Estas representam cerca de $55 \%$ dos materiais usados para a construção de motores e também são utilizadas na indústria aeroespacial devido à alta resistência ao calor e à deformação mecânica (CHOUDHURY \& EL-BARADIE, 1998; EZUGWU et al., 1999; VIGNEAU, 1997).

Atualmente, as aplicações para as superligas são muito extensas (CHOUDHURY \& EL-BARADIE, 1998; EZUGWU et al., 1999; SIMS et al., 1987). Os principais usos das superligas são:

(a) turbinas de gás do avião, por exemplo: discos, câmaras de combustão, parafusos, carcaças, sistemas de exaustão do eixo, lâminas, hélice etc;

(b) turbinas à vapor de plantas de energia, por exemplo: parafusos, lâminas;

(c) motores recíprocos, por exemplo: turbocharger, válvulas de exaustão etc.;

(d) processamento de metais, por exemplo: ferramentas para trabalho à quente e moldes, moldes forjados; 
(e) aplicações médicas, por exemplo: uso odontológico, dispositivo protético;

(f) veículos aeroespaciais;

(g) equipamentos de tratamento térmico;

(h) sistemas de reatores nucleares;

(i) indústrias químicas e petroquímicas;

(j) equipamentos do controle de poluição; e

(k) sistemas de gaseificação e de liquefação de carvão.

As superligas são divididas em: base níquel, base de ferro e base de cobalto. A Figura 2.28 mostra suas classificações.

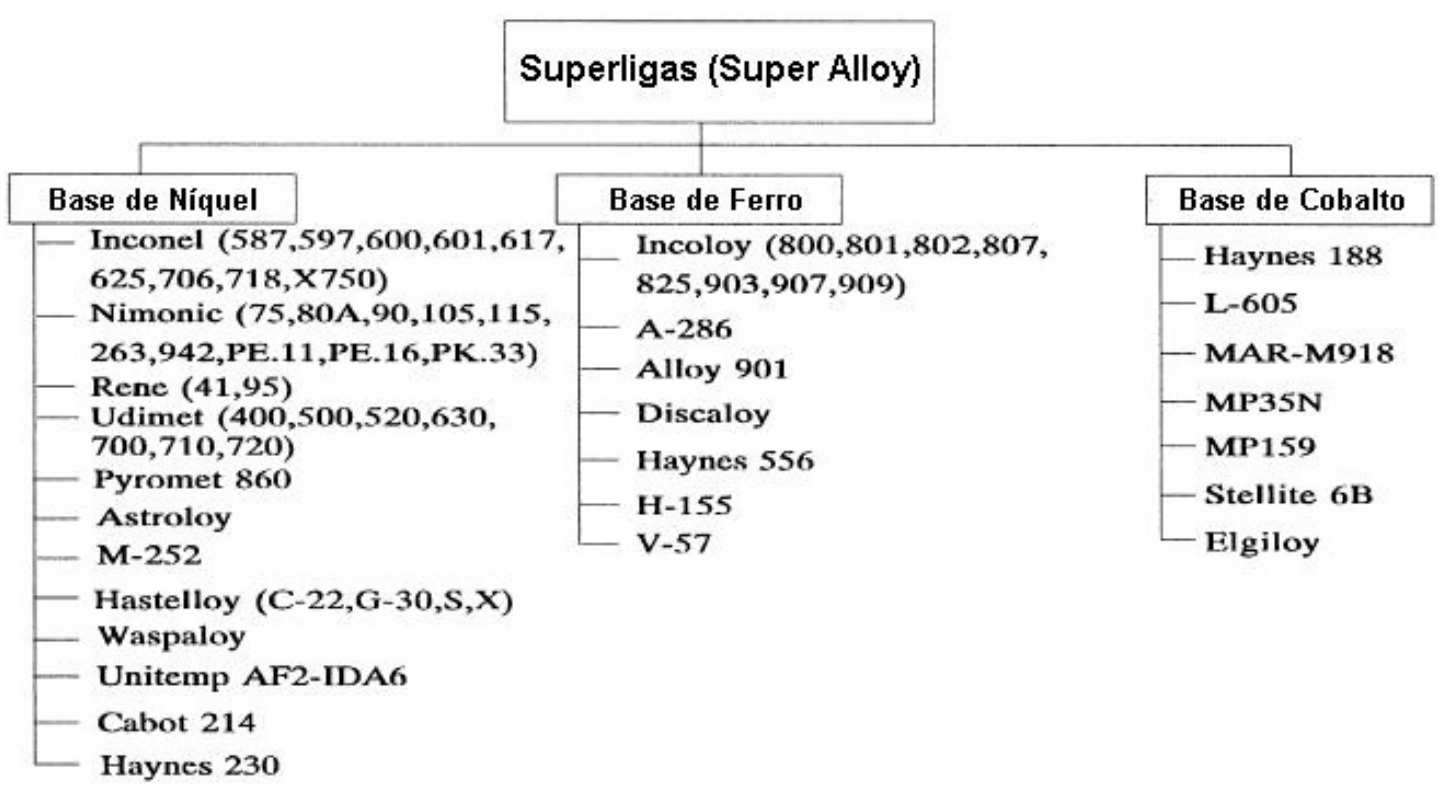

Figura 2.28 - Classificação de superligas (CHOUDHURY \& EL-BARADIE, 1998).

O ótimo desempenho em temperaturas elevadas é proveniente da alta temperatura de fusão de seus principais elementos básico, que são: ferro, níquel e cobalto além do cromo e outros elementos, utilizados para melhorar a resistência à oxidação e corrosão, como também a resistência mecânica.

As superligas contêm uma variedade de elementos, em um grande número de combinações, para proporcionar um ou mais dos seguintes efeitos: resistência a altas temperaturas através do mecanismo de endurecimento por solução sólida 
(molibdênio, tântalo e tungstênio), resistência à oxidação (cromo e alumínio), fase estável (níquel), aumento das frações volumétricas de precipitados secundários favoráveis (cobalto). Outros elementos são adicionados para formar precipitados resistentes, como a fase gama primária (alumínio e titânio) e a fase gama secundária (nióbio), além do carbono para a formação de carbonetos. (EZUGWU et al., 1999).

Choudhury \& Baradie (1998) e Ezugwu et al. (1999) apresentam a classificação, a composição química e a densidade das principais superligas à base de níquel, compilada na (Tabela 5). 
Tabela 5 - Composição química nominal (\% peso) e densidade das superligas à base de níquel forjadas (CHOUDHURY \& BARADIE, 1998 e EZUGWU et al., 1999).

\begin{tabular}{|l|c|c|c|c|c|c|c|c|c|c|c|c|c|}
\hline $\begin{array}{l}\text { Designação } \\
\text { da liga }\end{array}$ & Ni & $\mathbf{C r}$ & $\mathbf{C o}$ & $\mathbf{M o}$ & $\mathbf{W}$ & $\mathbf{A l}$ & $\mathbf{T i}$ & $\mathbf{F e}$ & $\mathbf{M n}$ & $\mathbf{S i}$ & $\mathbf{C}$ & $\mathbf{N b}$ & $\begin{array}{c}\text { Densi- } \\
\text { dade } \\
\mathbf{K g / \mathbf { m } ^ { 3 }} \mathbf{)}\end{array}$ \\
\hline Astroloy & 55.1 & 15.0 & 17.0 & 5.25 & - & 4.0 & 3.5 & - & - & - & 0.06 & - & 7.91 \\
\hline Hastelloy X & 47.3 & 22.0 & 1.5 & 9.0 & 0.6 & - & - & 18.0 & 0.50 & 0.50 & 0.10 & - & 8.22 \\
\hline Inconel 600 & 76.6 & 15.8 & - & - & - & - & & 7.2 & 0.20 & 0.20 & 0.04 & - & 8.33 \\
\hline Inconel 625 & 61.6 & 22.0 & - & 9.0 & - & 0.2 & 0.2 & 3.0 & 0.15 & 0.15 & 0.05 & 4.0 & 8.44 \\
\hline Inconel 706 & 41.5 & 16.0 & 0.5 & 0.5 & - & 0.2 & 1.7 & 40.0 & 0.18 & 0.18 & 0.03 & 2.9 & 8.08 \\
\hline Inconel 718 & 53.0 & 18.6 & - & 3.1 & - & 0.4 & 0.9 & 18.5 & 0.20 & 0.30 & 0.04 & 5.0 & 8.19 \\
\hline $\begin{array}{l}\text { Inconel X- } \\
750\end{array}$ & 73.0 & 15.0 & - & - & - & 0.8 & 2.5 & 6.8 & 0.70 & 0.30 & 0.04 & 0.9 & 8.30 \\
\hline IN-102 & 67.9 & 15.0 & - & 3.0 & 3.0 & 0.4 & 0.6 & 7.0 & - & - & 0.06 & 3.0 & 8.55 \\
\hline IN-853 & 74.6 & 20.0 & - & - & - & 1.5 & 2.5 & - & - & - & 0.05 & - & 8.09 \\
\hline Nimonic 75 & 78.8 & 20.0 & - & - & - & - & 0.4 & - & 0.10 & 0.75 & 0.01 & - & 8.37 \\
\hline $\begin{array}{l}\text { Nimonic } \\
80 A\end{array}$ & 74.7 & 19.5 & 1.1 & - & - & 1.3 & 2.5 & - & 0.10 & 0.70 & 0.06 & - & 8.22 \\
\hline Nimonic 90 & 57.4 & 19.5 & 18.0 & - & - & 1.4 & 2.4 & - & 0.50 & 0.70 & 0.07 & - & 8.18 \\
\hline $\begin{array}{l}\text { Nimonic } \\
115\end{array}$ & 57.3 & 15.0 & 15.0 & 3.5 & - & 4.0 & 4.0 & - & - & - & 0.15 & - & 7.85 \\
\hline $\begin{array}{l}\text { Nimonic } \\
120\end{array}$ & 63.8 & 12.5 & 10.0 & 5.7 & - & 4.5 & 3.5 & - & - & - & 0.04 & - & 7.95 \\
\hline Pyromet 860 & 43.0 & 12.6 & 4.0 & 6.0 & - & 1.2 & 3.0 & 30.0 & 0.05 & 0.05 & 0.05 & - & 8.23 \\
\hline René 41 & 55.3 & 19.0 & 11.0 & 10.0 & - & 1.5 & 3.1 & - & - & - & 0.09 & - & 8.25 \\
\hline René 95 & 61.3 & 14.0 & 8.0 & 3.5 & 3.5 & 3.5 & 2.5 & - & - & - & 0.15 & - & 8.23 \\
\hline Unimet 500 & 53.6 & 18.0 & 18.5 & 4.0 & - & 2.9 & 5.9 & - & - & - & 0.08 & - & 8.02 \\
\hline Unimet 710 & 54.9 & 18.0 & 15.0 & 3.0 & 1.5 & 2.5 & 5.0 & - & - & - & 0.07 & - & 8.08 \\
\hline Waspaloy & 58.3 & 19.5 & 13.5 & 4.3 & - & 1.3 & 3.0 & - & - & - & 0.08 & - & 8.19 \\
\hline
\end{tabular}

As ligas de níquel são endurecidas pela precipitação de $\mathrm{Ni}_{3}(\mathrm{Al}, \mathrm{Ti})$ fase gama e pela solução de elementos refratários na matriz. A alta resistência à temperatura é obtida pelo aumento da fração de volume desta fase. Os materiais mais avançados incluem $55 \%$ de fase gama para ligas utilizadas na metalurgia do pó e 70\% para ligas de cristal único (VIGNEAU,1997). 
A adição do cromo, quando em um ambiente oxidante e aquecido, produz uma camada protetora que contem $\mathrm{Cr}_{2} \mathrm{O}_{3}$ na superfície do material. O alumínio, titânio e nióbio são adicionados para a resistência à oxidação do material pela formação da fase y' gama primária $\left(\mathrm{Ni}_{3}(\mathrm{Al}, \mathrm{Ti})\right)$.

O molibdênio, o tungstênio e o tântalo são usados para fornecer a resistência da solução sólida na alta temperatura. $O$ boro e o zircônio são adicionados para aumentar a resistência e a ductilidade (EZUGWU et al., 1999).

Todos estes elementos de liga interagem de várias formas para promover limites de resistência, fluência e fadiga, além de resistência à oxidação. O mesmo vale para o controle da microestrutura do material fundido e os subseqüentes tratamentos térmicos de solubilização e envelhecimento.

Segundo Vigneau (1997) e Ezugwu et al. (1999), os motivos que contribuem para a baixa usinabilidade das ligas a base de níquel são:

(i) projetadas para operar a altas temperaturas, elas mantêm alta resistência mesmo a temperaturas de corte elevadas;

(ii) a estrutura austenítica (CFC) produz um severo endurecimento da peça, principal fator que contribui para forças de corte, tensões elevadas e ao desgaste da ferramenta de corte;

(iii) as ferramentas de corte sofrem um severo desgaste abrasivo devido à presença de carbonetos duros na matriz;

(iv) reações químicas que ocorrem em altas temperaturas na usinagem, conduzindo a uma taxa elevada do desgaste pela difusão;

(v) tendências destes materiais se aderirem às superfícies das ferramentas. Isto é mais crítico no processo de fresamento, pois a ferramenta ao sair do corte, mantém consigo o cavaco aderido à sua superfície de saída, o que além de prejudicar o acabamento superficial, causa lascamento de ferramenta na reentrada do corte;

(vi) a alta fração de volume das partículas da fase de elevada dureza produz abrasão severa das ferramentas; e

(vii) a condutividade térmica é baixa, o que contribui para 0 desenvolvimento de altas temperaturas na região de contato e a presença de elevado gradiente térmico na ferramenta de corte.

Todos estes fatores operando juntos ou em combinação causam altas temperaturas de corte (podem chegar a $1000^{\circ} \mathrm{C}$ ) e alta tensão (pressão) na região 
de contato (pode chegar a $3450 \mathrm{MPa}$ ) o que leva ao desenvolvimento rápido do desgaste, dependendo do material da ferramenta e das condições de corte.

Devido à estas condições desfavoráveis a retificação de superligas induz efeitos na integridade da superfície, os quais incluem rugosidade, microestrutura e tensões residuais.

\subsubsection{Integridade superficial e as relações de parâmetros na retificação de superligas à base de níquel}

De acordo com Weingaertner et al. (2001), no processo de retificação os danos térmicos podem ser entendidos como as modificações das características físicas e/ou químicas da superfície retificada como também daquelas regiões as quais se localizam abaixo desta superfície.

Estes danos na peça podem ser expressos em termos da profundidade da zona afetada pelo calor em relação à superfície retificada, camadas de óxido na superfície, tensões residuais, microtrincas, macrotrincas, redução ou aumento de dureza da zona afetada e a redução da vida à fadiga.

Uma das grandes causas do aparecimento dos danos térmicos nas peças são as elevadas temperaturas que aparecem na região de corte.

A pesquisa de Shafto (1975) apud Howes (1990) mediu o gradiente de temperaturas em um corpo de prova de liga a base de níquel sendo retificado pelo processo creep-feed usando fluido à base de água. Usando os termopares encaixados no corpo de prova, notou-se que o processo foi satisfatório somente em temperaturas abaixo do ponto de ebulição da água (Figura 2.29). Por outro lado, um superaquecimento catastrófico e repentino do corpo de prova ocorreria se a temperatura de ebulição da película fosse excedida. 
Parâmet ro de retificaçẫo:

\section{Escala:}

Profundidade de corte: $6,0 \mathrm{~mm}$

Avanço: 0,187 mm/s

Velocidade do rebolo: $30 \mathrm{~m} / \mathrm{s}$

Material: Nimonic C1023

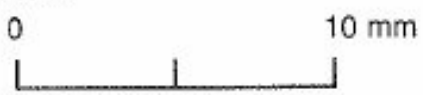

Temperaturas: ${ }^{\circ} \mathrm{C}$

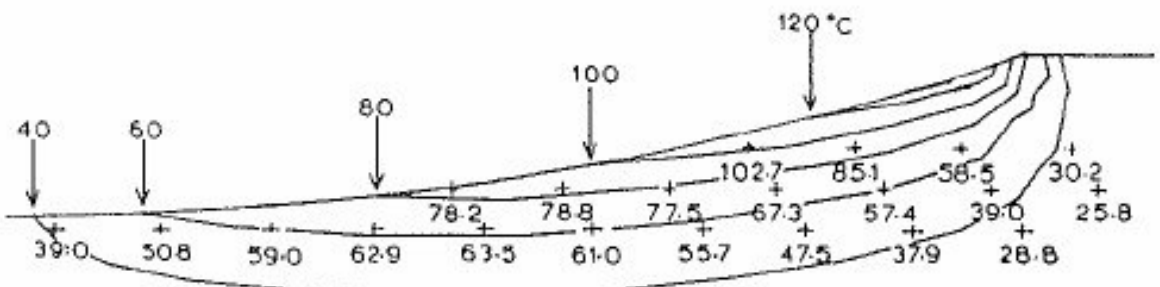

Figura 2.29 - Gradiente térmico na retificação de "creep-feed" (SHAFTO, 1975 apud HOWES, 1990).

Seus resultados mostraram também que, sob condições satisfatórias de retificação, a fração da energia que passa para o corpo de prova como calor energia de partição - era mais baixa que os valores relatados por investigações precedentes.

De acordo com Vigneau (1997), Ezugwu et al. (1999) e Weingaertner et al. (2001), a usinagem de superligas induz efeitos na integridade da superfície, os quais incluem:

- Alta rugosidade superficial;

- Modificações na dureza da camada superficial devido ao endurecimento da peça;

- Microtrincas ou macrotrincas (particularmente na retificação);

- Deformação plástica;

- Transformações metalúrgicas atribuídas à alta temperatura;

- Tensões residuais (tração ou compressão);

- Alterações químicas incluindo alta temperatura de oxidação e difusão entre a peça e o material da ferramenta.

As temperaturas na retificação dependerão dos parâmetros de corte, especificação do rebolo, máquina-ferramenta, material da peça, condições de dressagem e fluido de corte, etc. Conforme a Figura 2.30., se a velocidade da peça $(\mathrm{Vw})$ for aumentada, haverá um decréscimo na temperatura. Se a velocidade da peça for mantida constante e a taxa de remoção específica (Q'w) e 
a profundidade de corte (a) forem aumentada, haverá um acréscimo na temperatura.

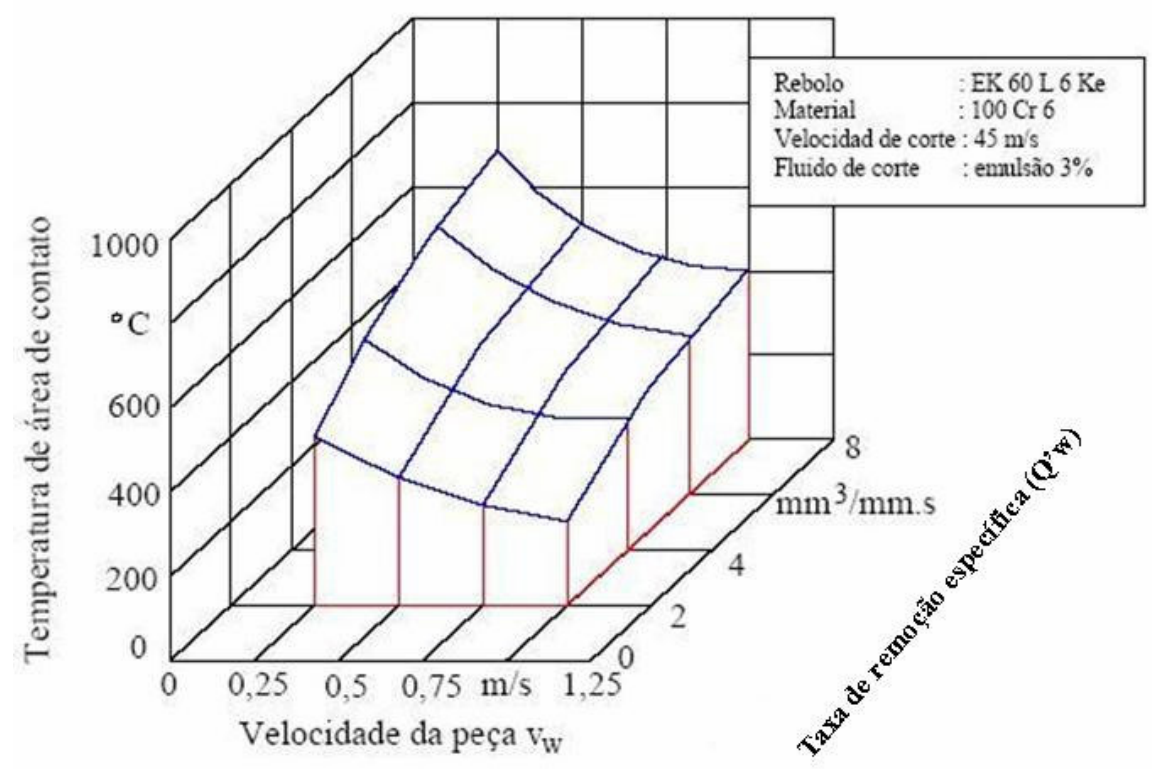

Figura 2.30 - Variação da temperatura no processo de retificação em função dos parâmetros de corte (TÖNSHOFF et al., 1992).

Diversos autores pesquisaram o efeito da temperatura em relação à integridade da superfície de superligas na retificação.

Segundo o estudo dos autores Xu \& Yu (2002), a temperatura da interface em relação às diferentes condições de retificação são mostradas na Figura 2.31. Encontraram-se diferentes cores nas experiências e foi possível reconhecer o aparecimento da cor relacionada à queima nas superfícies do corpo de prova quando a temperatura na interface é maior que $990^{\circ} \mathrm{C}$. Notou-se que quanto mais elevada à temperatura da interface de contato, mais escura é a cor na superfície.

As imagens feitas pelo microscópio eletrônico de varredura (MEV) das superfícies retificadas e de diferentes cores são apresentadas. Foram encontradas algumas microtrincas na superfície de cor azul indicando severas queimas na face retificada. 


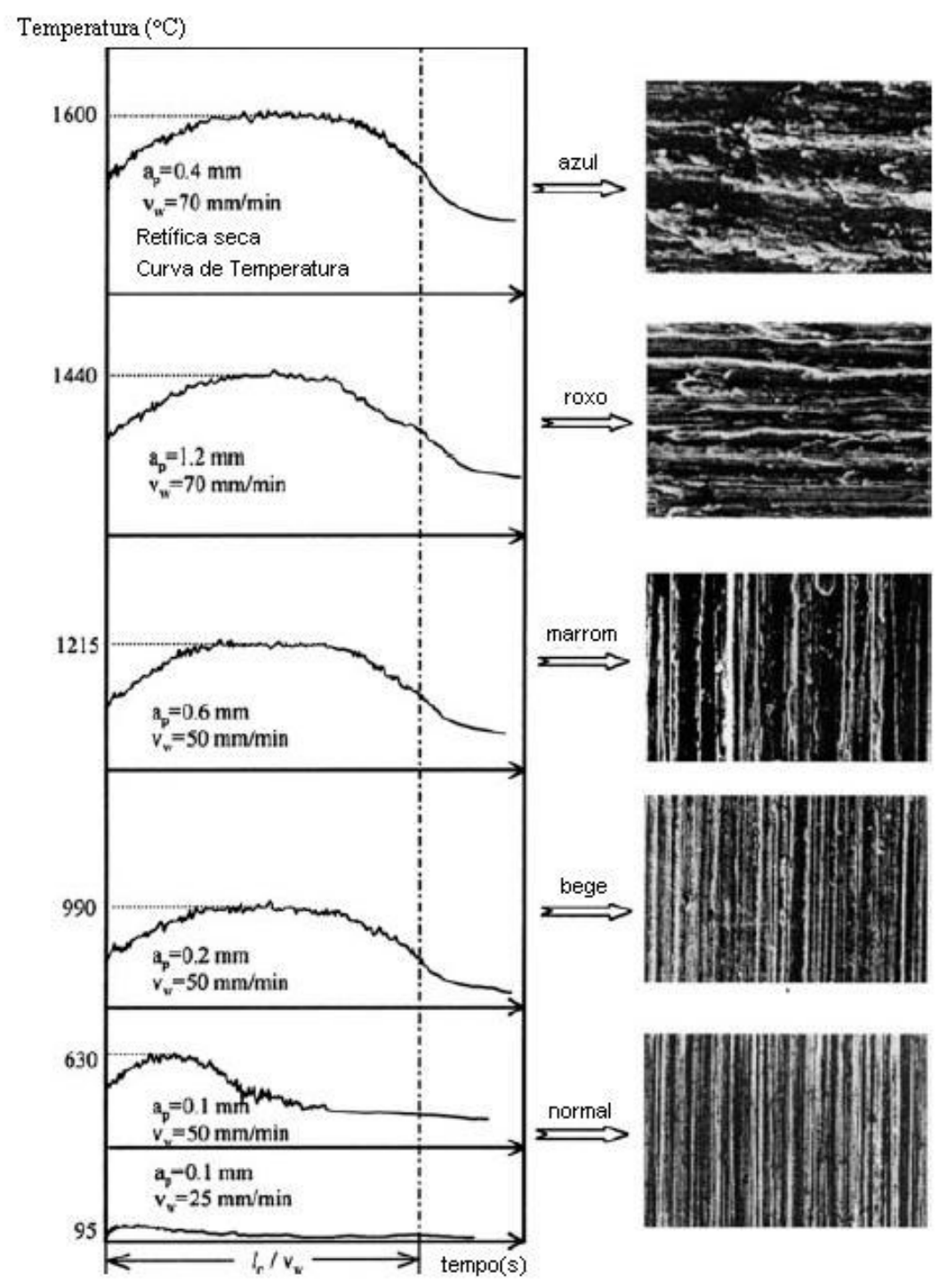

Figura 2.31 - Curva de temperatura e MEV da superfície da peça retificada (XU \& YU, 2002).

Os valores de rugosidade medidos para as superfícies de cores diferentes são traçados em um gráfico contra as temperaturas máximas (Figura 2.32). Podese observar que a rugosidade aumenta com o aumento da temperatura. 


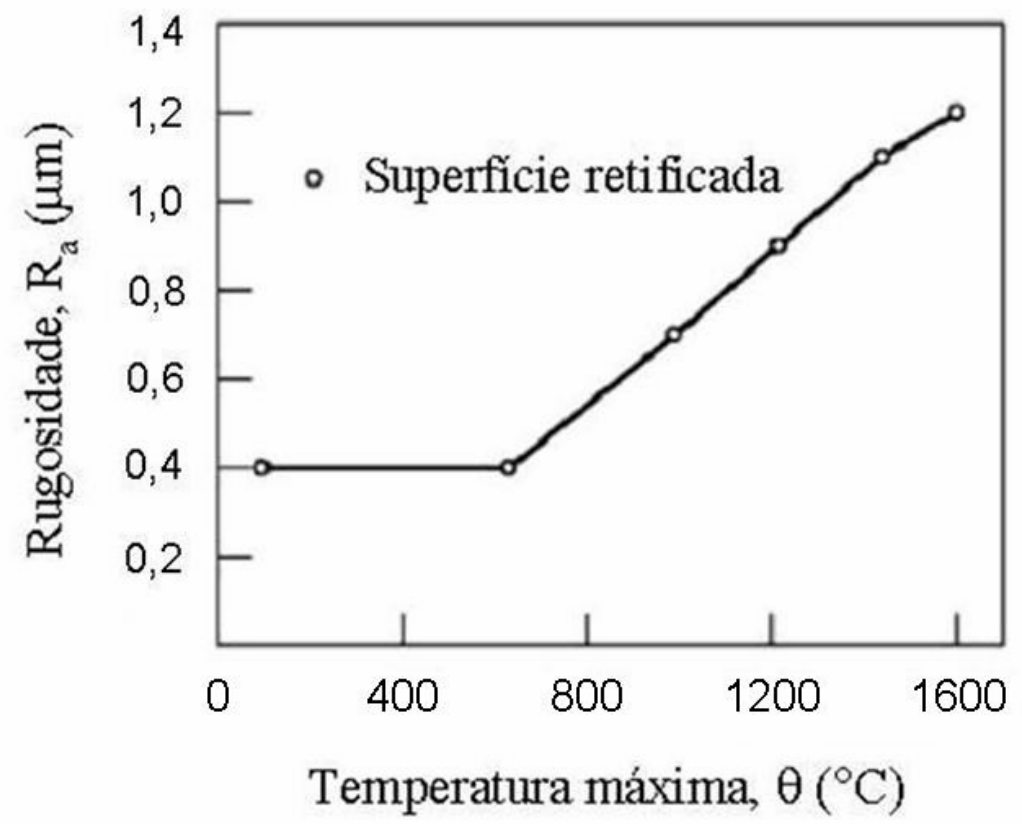

Figura 2.32 - Rugosidade superficial versos temperatura máxima (XU et al., 2002, modificada).

Foram medidas as tensões residuais nas diferentes profundidades das superfícies retificadas. De acordo com a Figura 2.33, somente as tensões perpendiculares ao sentido de retificação são apresentadas. Pode-se observar que as tensões compressivas foram geradas nas superfícies e sub-superfícies das peças retificadas. Os valores das tensões de compressão aumentam progressivamente até um valor máximo com o aumento da profundidade. Após atingir este valor, as tensões diminuem e estabilizam no valor de tensão do metal base. A tensão máxima na superfície de cor roxa é ligeiramente menor do que para as outras duas cores e a localização da tensão máxima é distante em relação à superfície retificada. Este comportamento é similar ao encontrado na retificação com CBN e na fresagem de face (XU et al., 2002). 


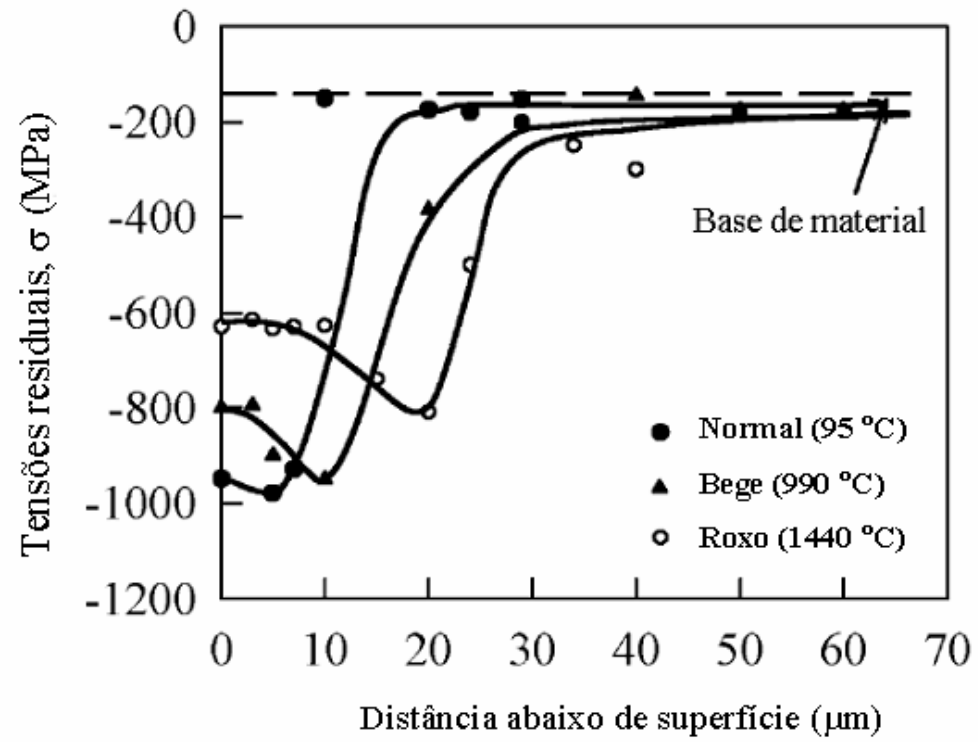

Figura 2.33 - Tensões residuais abaixo de superfície da peça (Xu et al., 2002).

Ichida \& Kishi (1997) em sua pesquisa compararam grãos nanocristalinos que possuem diâmetros médios menores que $1 \mu \mathrm{m}$ com grãos policristalinos de $2.3 \mu \mathrm{m}$ de CBN na retificação de superligas.

Encontrou-se que os grãos nanocristalinos de CBN possuem alta resistência de fratura, o que proporciona redução de desgaste e aumenta a vida do rebolo de retificação. A análise da distribuição da aresta de corte mostra que a taxa do desgaste reduzida dos grãos nanocristalinos de CBN é devido à predominância de uma modalidade de micro-fratura do desgaste abrasivo. $\mathrm{O}$ tamanho desta micro-fratura é consideravelmente menor nos nano do que nos policristalinos.

A Figura 2.34 apresenta uma comparação de medidas da rugosidade superficial. Todos os três tipos de grãos começam no mesmo nível da rugosidade. Para os grãos monocristalinos, a rugosidade superficial aumenta rapidamente durante a vida do rebolo, de menos que $2 \mu \mathrm{m} R z$ para $3.5 \mu \mathrm{m} R z$. Já, para os grãos policristalinos, há um aumento mais gradual para $3 \mu \mathrm{m} \mathrm{Rz}$. A rugosidade aumenta ainda mais suavemente para os nanocristalinos, sendo seu valor de pico menos de $3 \mu \mathrm{m} \mathrm{Rz}$. Estes resultados indicam uma maior estabilidade ao processo de retificação usando grãos nanocristalinos. 


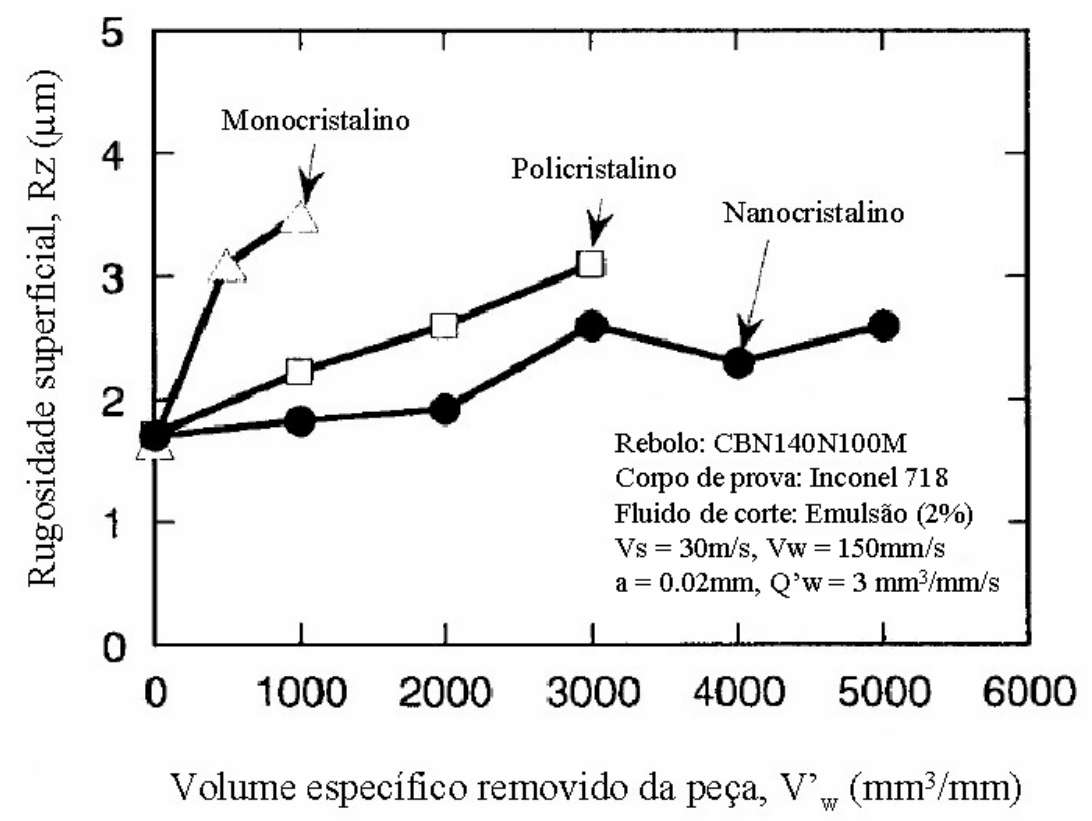

Figura 2.34 - Efeito de tipos de grãos na variação de rugosidade em função de material removido (ICHIDA \& KISHI, 1997).

Os autores também resumem os valores obtidos para os três tipos de grãos ao retificar duas superligas à base de níquel em duas taxas diferentes de remoção (Figura 2.35). As magnitudes relativas são similares, dando o grão nanocristalino um valor de relação de retificação $G$ consistentemente mais elevado. Para os três tipos de grãos, valores ligeiramente mais elevados foram obtidos retificando Nimonic $80 \mathrm{~A}$, enquanto que números aproximadamente correspondentes à metade dos valores anteriores foram conseguidos com a taxa de remoção maior. 


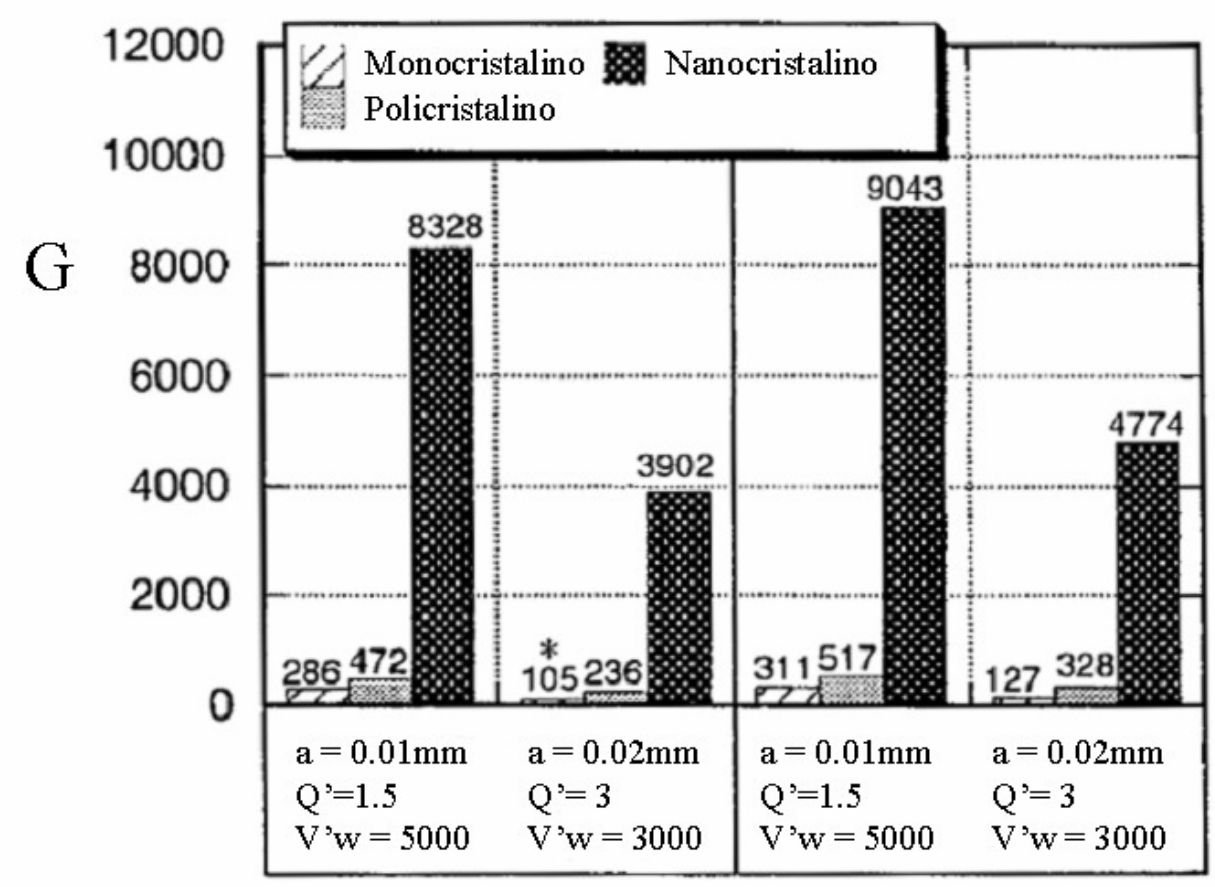

Inconel 718

Nimonic 80A

Rebolo: CBN140N100M, Fluido de corte: Emulsão (2\%),

$\mathrm{Vs}=30 \mathrm{~m} / \mathrm{s}, \mathrm{Vw}=150 \mathrm{~mm} / \mathrm{s}, \mathrm{Q}^{\prime} \mathrm{w}=\mathrm{mm} 3 / \mathrm{mm} / \mathrm{s}$,

$\mathrm{V}^{\prime} \mathrm{w} \mathrm{mm} 3 / \mathrm{mm},\left(^{*}: \mathrm{V}^{\prime} \mathrm{w}=1000 \mathrm{~mm} 3 / \mathrm{mm}\right)$

Figura 2.35 - Efeito de tipos de grãos em função de relação de retificação $(G)$ em diversas condições (ICHIDA \& KISHI, 1997).

Segundo Ichida (2001), sua pesquisa apresenta os efeitos de diferentes tipos de grãos nas variações de força de retificação de acordo com o aumento de material removido da peça. Para ambos os tipos de rebolos de CBN, a força normal de retificação começa alta e depois diminui, tendendo a um valor constante. Os grãos abrasivos na superfície durante o processo de retificação tornam-se mais expostos, enquanto o excesso de ligante é removido constantemente pelo contato de superfície da peça com o rebolo (Figura 2.36). 


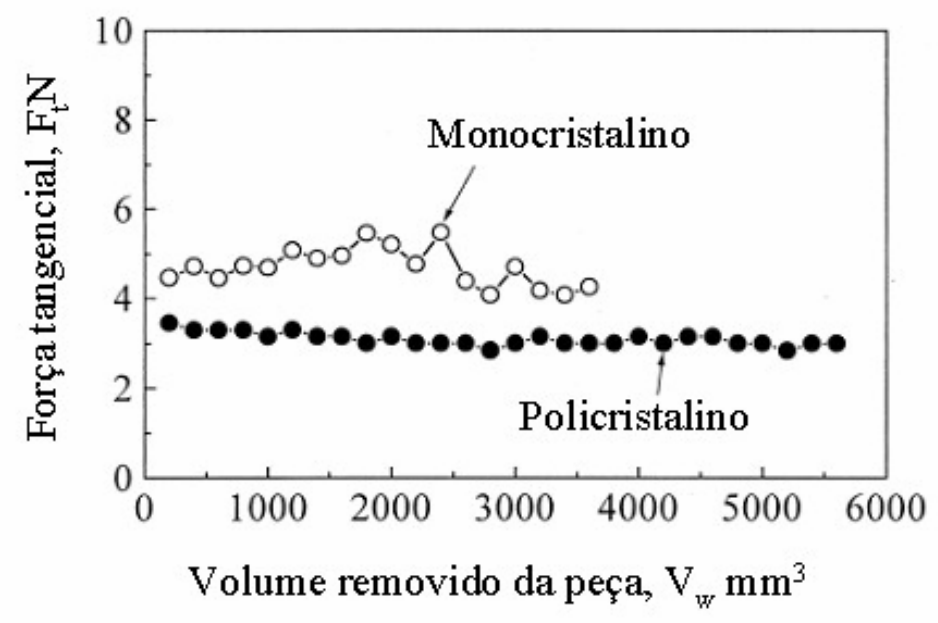

(a) Força tangencial de retificação

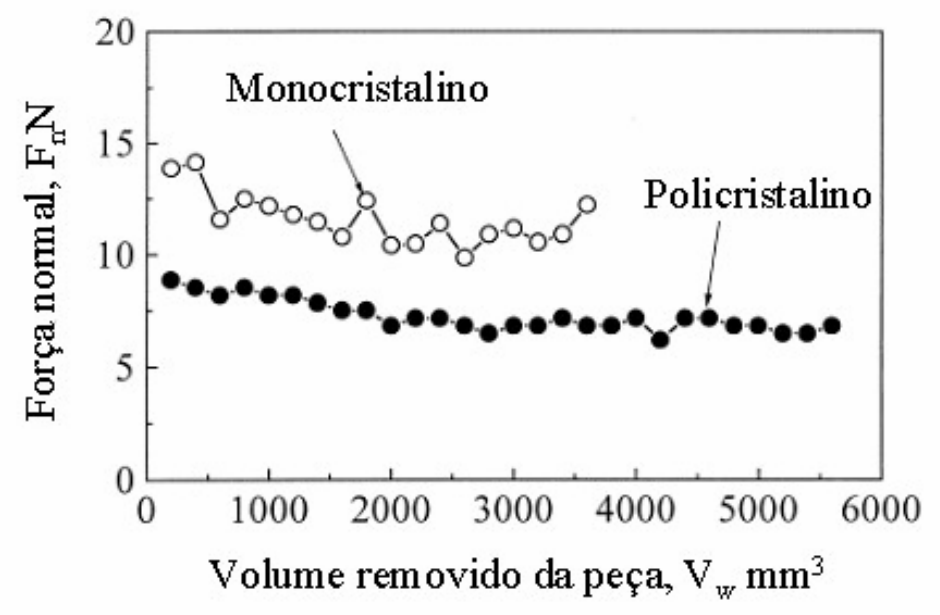

(b) Força normal de retificação

Figura 2.36 - Efeito de tipos de grãos na variação de forças de retificação em função de aumento de material removido (Vs $=2600 \mathrm{~m} / \mathrm{min}, \mathrm{Vw}=15 \mathrm{~mm} / \mathrm{min}, \mathrm{a}=$ $2 \mathrm{~mm}$ ) (ICHIDA, 2001).

As forças de retificação durante o processo com o rebolo de CBN policristalino são 20 30\% mais baixos do que aqueles com CBN monocristalino. Este relacionamento entre forças de retificação e o volume removido da peça sugere que o potencial de manter a capacidade da retificação é mais elevado com rebolo de CBN policristalino do que aqueles com CBN monocristalino. 
A Figura 2.37(a) apresenta os efeitos de diferentes tipos de grãos sobre a variação de desgaste radial do rebolo com o aumento de material removido da peça. $O$ desgaste radial $\Delta R$ com rebolo de grão monocristalino aumenta gradualmente entre 800 a $2800 \mathrm{~mm}^{3}$ de material removido e cresce rapidamente depois de $2800 \mathrm{~mm}^{3}$. Os experimentos de retificação foram interrompidos depois de $3600 \mathrm{~mm}^{3}$ de material removido, devido ao desgaste radial do rebolo ter ultrapassado $20 \mu \mathrm{m}$. Quando se atinge um volume de remoção de material de aproximadamente $2800 \mathrm{~mm}^{3}$, necessita-se dressar o rebolo; por outro lado, usando CBN policristalino, o desgaste radial é menor que $4 \mu \mathrm{m}$ para $V w=5600$ $\mathrm{mm}^{3}$. O desgaste volumétrico do rebolo também segue o mesmo comportamento, como ilustrada na Figura 2.37(b). 


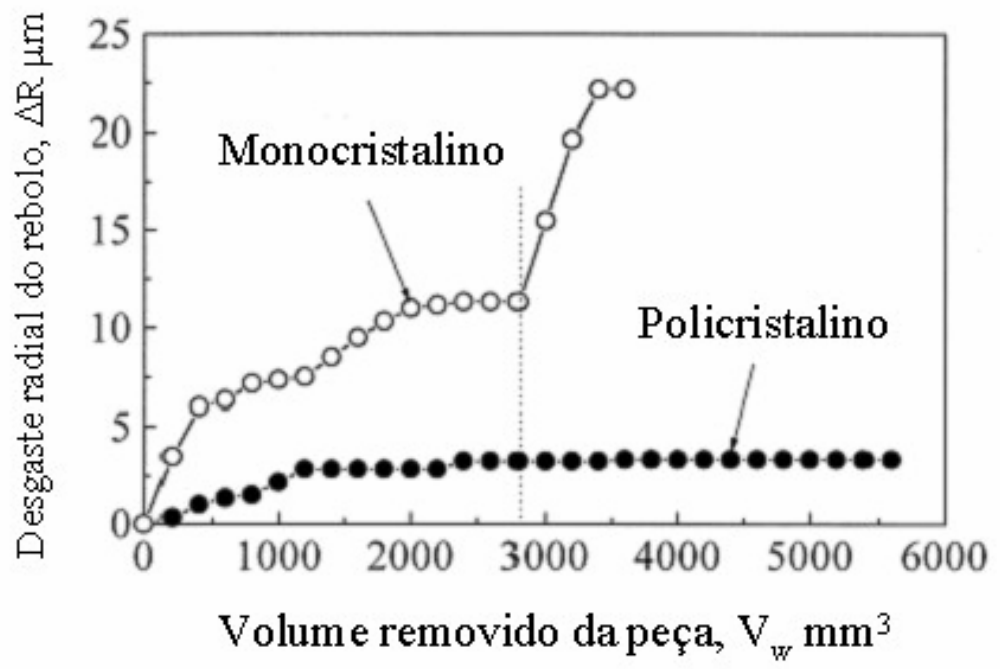

(a) Desgaste radial do rebolo

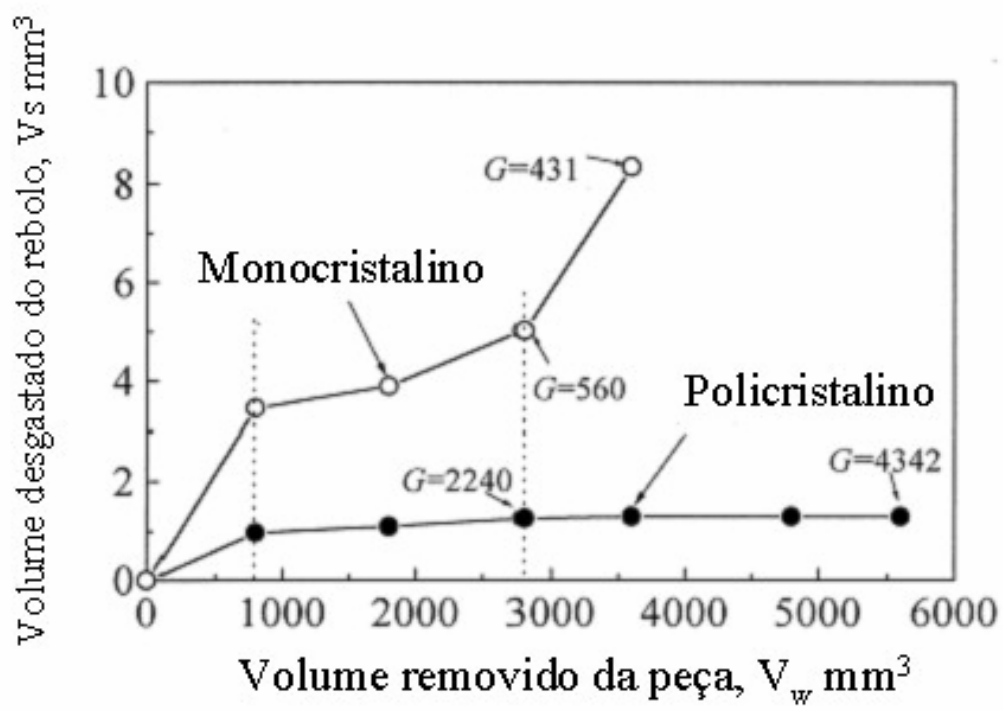

(b) Desgaste volumétrico do rebolo

Figura 2.37 - Efeito de tipos de grãos na variação de desgaste radial e volumétrico do rebolo de retificação em função de aumento de material removido $(V s=2600 \mathrm{~m} / \mathrm{min}, \mathrm{Vw}=15 \mathrm{~mm} / \mathrm{min}, \mathrm{a}=2 \mathrm{~mm})($ ICHIDA, 2001).

Estes resultados mostram que a taxa média de desgaste do rebolo policristalino é aproximadamente um valor de ordem mais baixa do que aquela do rebolo monocriatalino. A relação de retificação $G$ pode ser obtida determinando-se o volume de material removido pelo volume do desgaste do rebolo. Para uma 
remoção de material de $2800 \mathrm{~mm}^{3}$, a relação G é de $560 \mathrm{com}$ o rebolo de grão monocristalino, enquanto que com o rebolo de grão policristalino, tem-se 2240. Esta diferença na relação de $G$ tende a tornar-se maior, de acordo com o aumento de volume de material removido e da taxa de remoção utilizada.

Apesar dos resultados apresentados mostrarem uma importante correlação entre o tipo de $\mathrm{CBN}$ e o desgaste do rebolo na retificação de superligas, não há muita informação sobre como a severidade da operação pode influenciar no processo de desgaste do rebolo e nos resultados da retificação de superligas com CBN. Entender essas relações é um dos principais objetivos do presente trabalho. 


\section{MATERIAIS E MÉTODOS}

Este capítulo tem o objetivo de descrever todos os equipamentos, materiais e métodos utilizados nesta pesquisa experimental, de modo a registrar os procedimentos, possibilitando a reprodução dos experimentos.

O trabalho experimental foi realizado no Laboratório de Otimização de Processos de Fabricação - OPF, no Núcleo de Manufatura Avançada - NUMA, do Departamento de Engenharia de Produção da Escola de Engenharia de São Carlos - USP.

\subsection{Equipamentos utilizados}

\subsubsection{Retificadora}

Os ensaios de retificação foram executados na retificadora cilíndrica Zema modelo - G800 HS (Figura 3.1). Esta máquina tem as seguintes características:

Comando CNC de arquitetura aberta- GE Fanuc 18iT;

Sistema de dressagem a alta velocidade com disco diamantado;

Máxima velocidade de corte de $100 \mathrm{~m} / \mathrm{s}$;

Máxima potência disponível do motor $15 \mathrm{cv}(11.34 \mathrm{kw})$;

Mancal hidrostático no eixo porta-rebolo;

Sistema de monitoramento de Emissão Acústica - Sensis;

Sistema de aplicação de fluido de corte com bocais otimizados. 


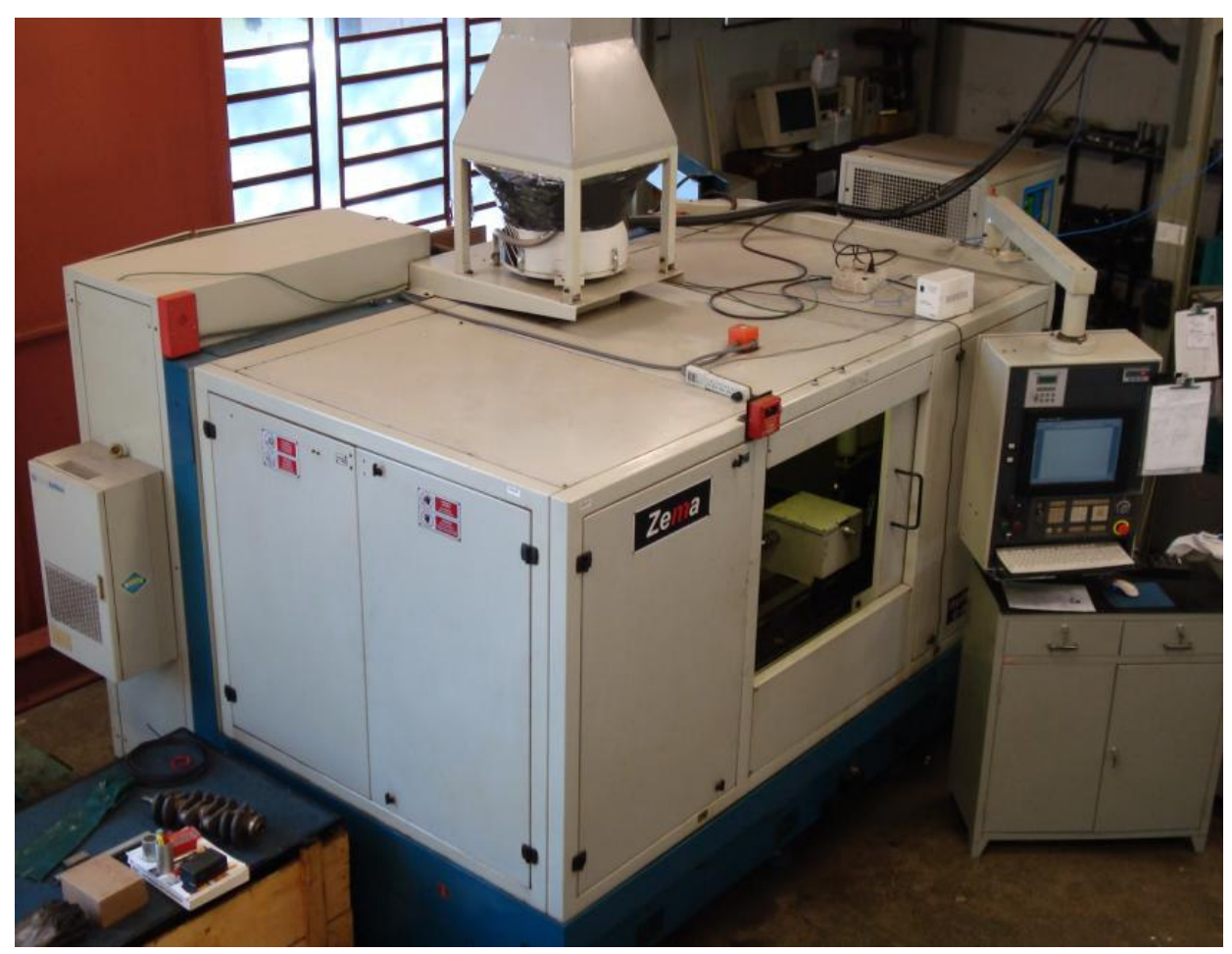

Figura 3.1 - Retificadora Zema G800 HS.

\subsubsection{Rebolo, dressador e parâmetro de dressagem}

A retificadora Zema é equipada com o rebolo de superabrasivo de $\mathrm{CBN}$, de especificação B181 $124 \mathrm{~V}$, com ligante vitrificado, de dimensões é 408 x $136 \mathrm{x}$ $23.8 \mathrm{~mm}$ e sua camada útil de CBN é $8 \mathrm{~mm}$ do fabricante Saint Gobain (Figura 3.2).

O dressador utilizado foi disco diamantado com acionamento por unidade elétrica. As condições de dressagem foram determinadas pelos diversos ensaios no laboratório, são:

Velocidade de rebolo $(\mathrm{Vs})=80 \mathrm{~m} / \mathrm{s}$

Velocidade de dressador $(\mathrm{Vr})=32.3 \mathrm{~m} / \mathrm{s}$

$(q d=0.404)$

Velocidade de dressagem $(\mathrm{Vd})=100 \mathrm{~mm} / \mathrm{min}$

Profundidade de dressagem $(\mathrm{ad})=2 \mu \mathrm{m}$ 


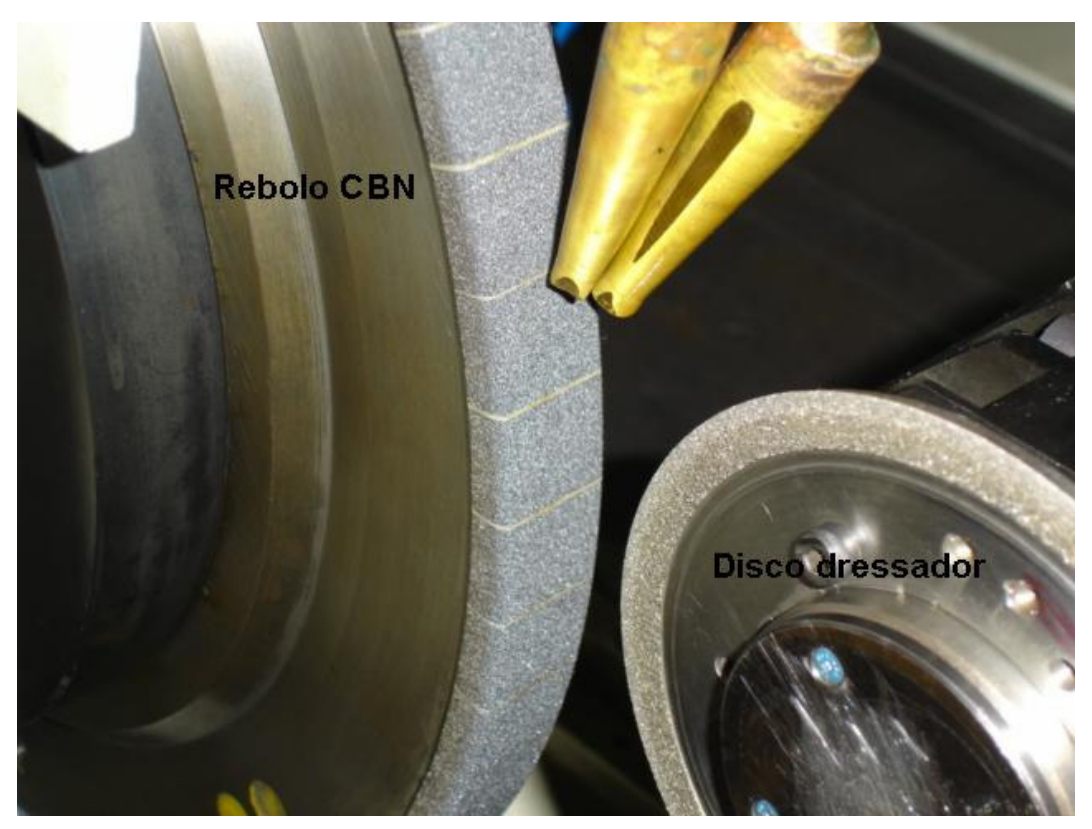

Figura 3.2 - Rebolo de superabrasivo de CBN.

\subsection{Equipamentos do sistema de aquisição de dados}

\subsubsection{Emissão Acústica}

Para a medição da emissão acústica foi utilizado um sensor sem contato, conectado a uma unidade de tratamento de sinal, modelo MSM, ambos fabricados pela empresa SENSIS (Figura 3.3). Esta unidade de tratamento de sinais filtra e amplifica o sinal e ainda é responsável pelo cálculo do valor médio quadrático RMS (Root Mean Square). 


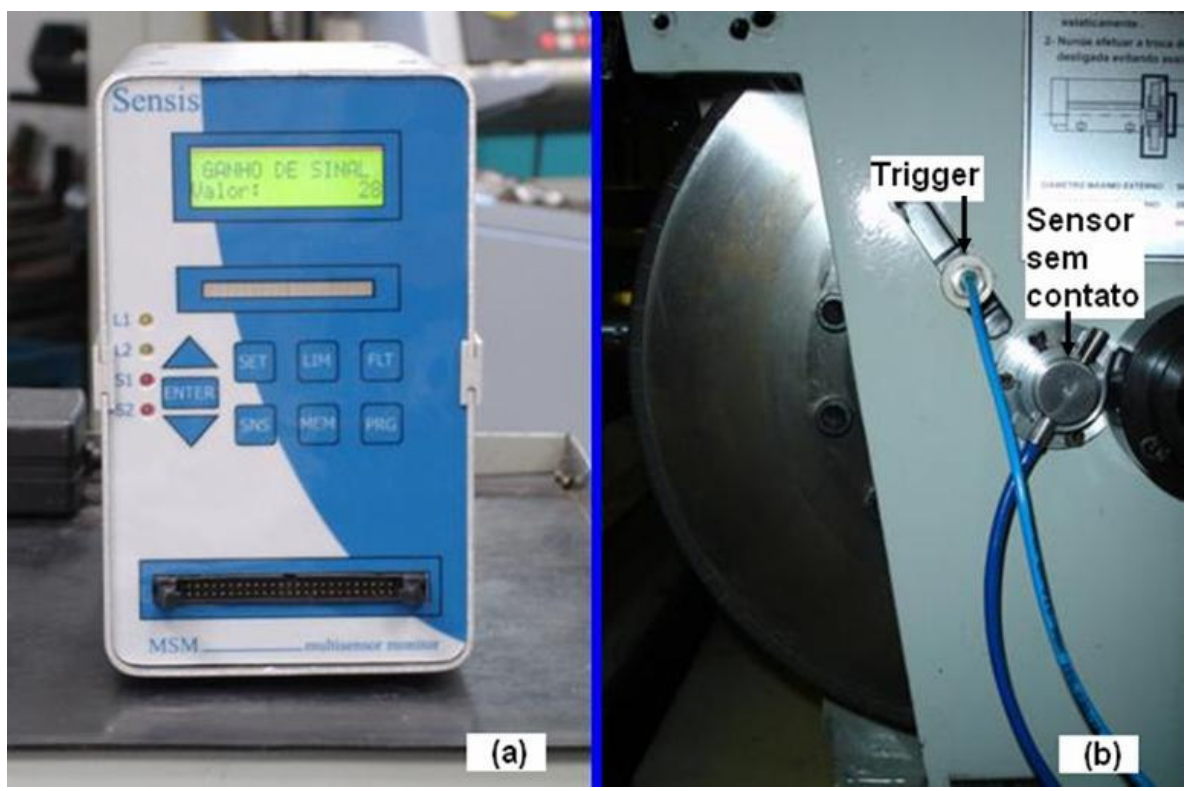

Figura 3.3 - (a) unidade de tratamento de sinal de emissão acústica; (b) sensor sem contato.

A aquisição e análise de sinais provenientes dos sensores citados são feitos com o uso de um software de aquisição de sinais. A versão 7.1 do LabView (Laboratory Virtual Instrument), da empresa National Instruments, é um ambiente de desenvolvimento baseado em programação com linguagem gráfica. Oferece ferramentas gráficas e boa interface com o usuário na criação de virtual instruments (VIs). A aquisição dos sinais é feita por uma placa de aquisição de dados, onde o sensor é conectado ao hardware e seus sinais são tratados pelo software.

A Figura 3.4 mostra a tela principal do VI com todos os mostradores ou displays de apresentação das grandezas medidas e seus respectivos campos de destino de gravação. 


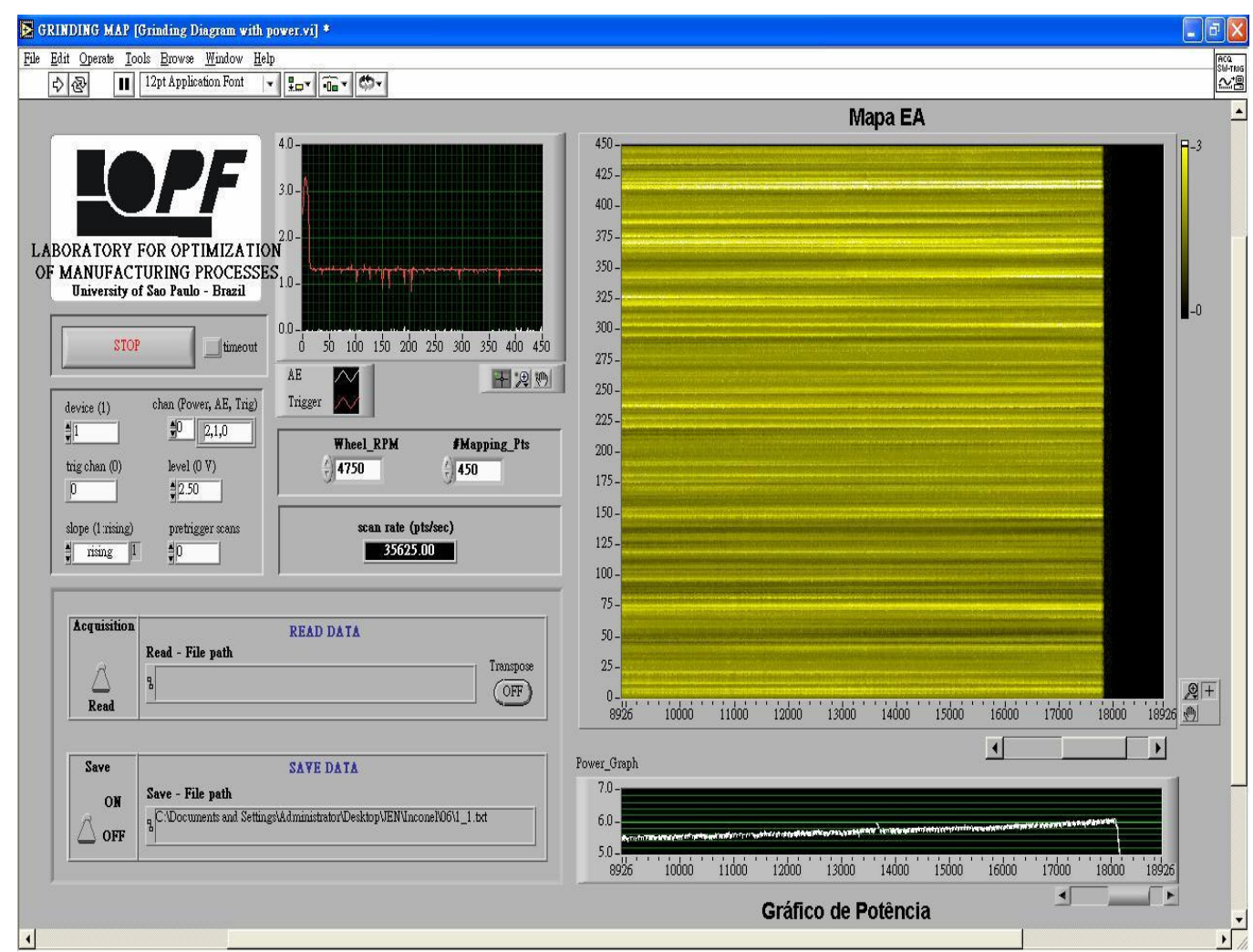

Figura 3.4 - Tela principal do programa de aquisição de dados (VI).

Foram realizados diversos ensaios preliminares para determinar a melhor regulagem do sistema de medição da EA para obter boa resposta do nível do sinal RMS sem que este saturasse.

\subsubsection{Potência elétrica do motor}

O sinal de potência é obtido através da corrente elétrica do inversor de freqüência da máquina. O inversor de freqüência VariSpeed 616G5 possui uma saída de 10V, através da qual pode-se obter a variação da corrente elétrica durante o processo de retificação. Essa corrente elétrica é proporcional à potência de retificação permitindo assim obter o sinal de potência do processo. A Figura 3.5 apresenta um esquema da parte traseira da máquina onde está localizado o painel elétrico que acondiciona o inversor de freqüência. 


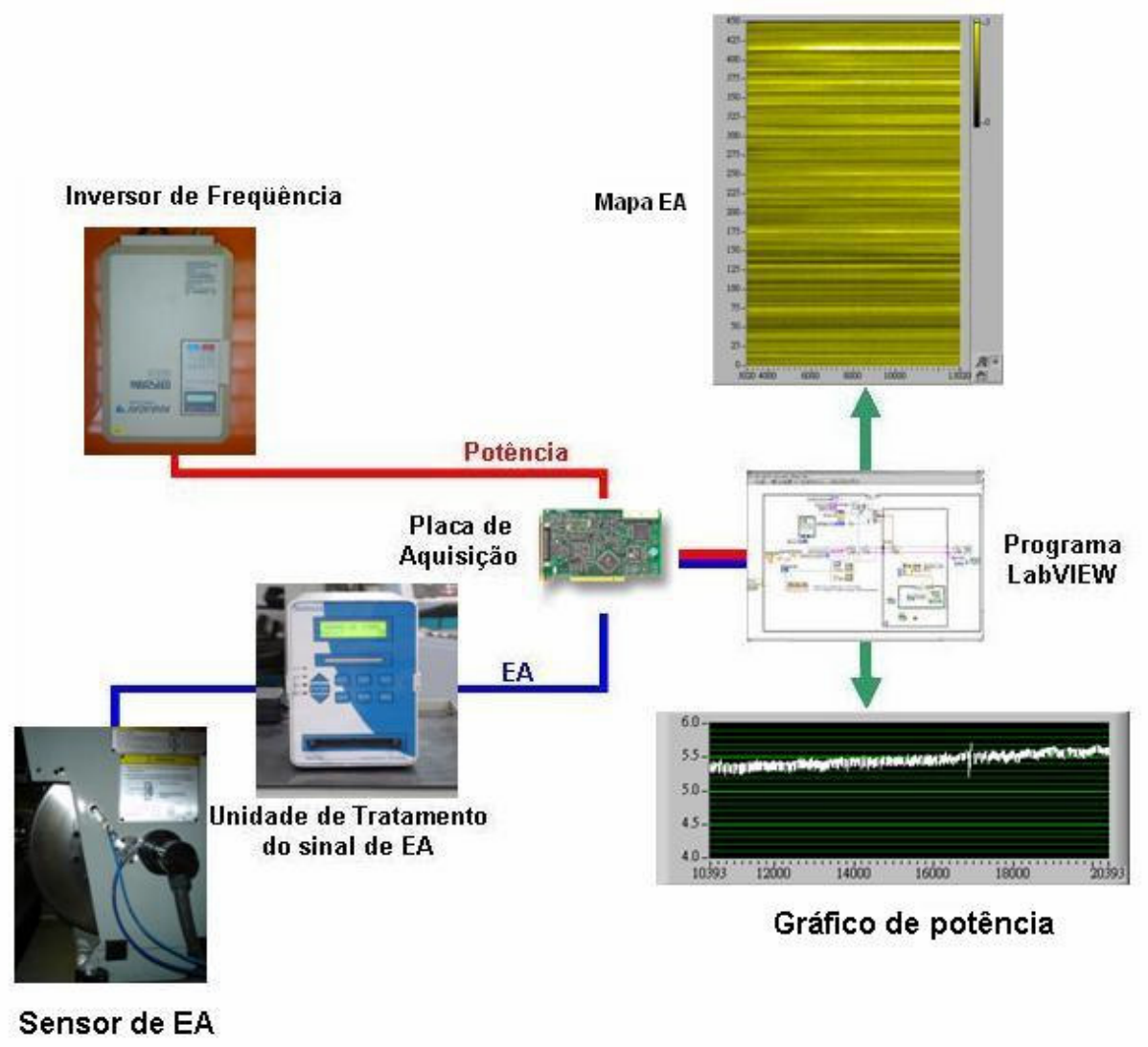

Figura 3.5 - Esquema geral do sistema de monitoramento.

\subsection{Medição da rugosidade e circularidade}

A rugosidade da peça foi medida em um rugosímetro da marca Mitutoyo modelo SJ201 (Figura 3.6). Este equipamento é capaz de fazer medição de rugosidade nos parâmetros Ra, Ry, Rz, Rq. Tem a possibilidade de se configurar o valor do comprimento da amostragem (cut-off), assim como o número de cut-off de uma medição. Para o experimento, o equipamento foi configurado com cut-off de $0,25 \mathrm{~mm}$ com cinco repetições.

Ao final das medições, foram obtidos os valores médios de cada peça e, em seguida, o valor médio das três repetibilidades referente a cada grupo de ensaios. 


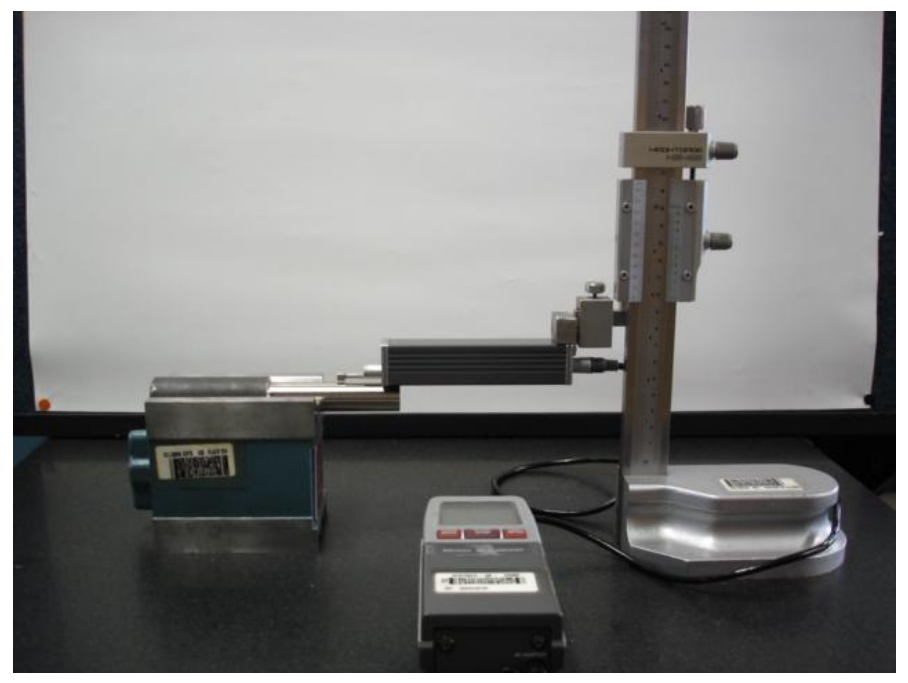

Figura 3.6 - Rugosímetro Mitutoyo SJ201.

Para a medição da circularidade, utilizou-se 0 equipamento TALYROND131, do fabricante TAYLOR HOBSON. Na Figura 3.7 mostra-se a fixação e a medição do erro de circularidade. É possível observar todos os componentes do aparelho de medição na mesma figura.

A peça foi fixada pelas castanhas da placa do equipamento, verificando-se a melhor posição de fixação. Foram executadas três medições em três posições distintas ao longo do comprimento da peça. A largura total da peça para cada passe de retificação foi de $5 \mathrm{~mm}$. Portanto, foi realizado um deslocamento axial na máquina (vertical) de $1 \mathrm{~mm}$ entre cada medição. Ao final das três medições, foram obtidos os valores médios de cada peça. 


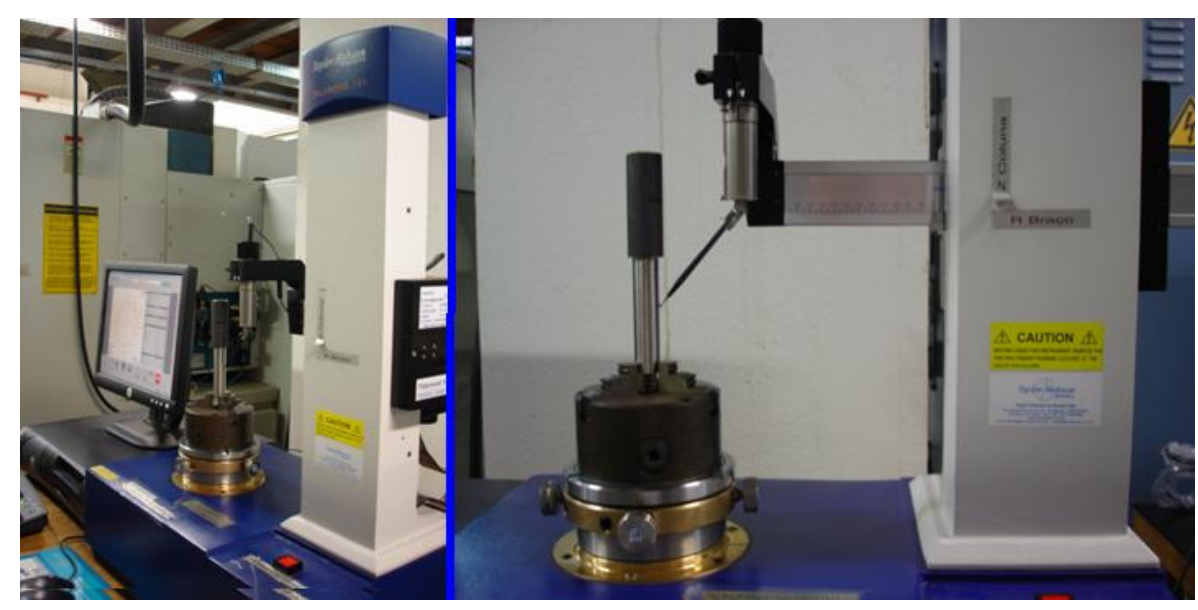

Figura 3.7 - TALYROND131.

\subsection{Corpo de prova}

Para o corpo de prova foram utilizados três tipos de materiais diferentes, entre eles são: Inconel (751), Silcrome 1 (VV45) e 21 - 2N (VV56).

O inconel é uma superliga a base de níquel e possui a pior usinabilidade, já o silcrome é um material martensítico e tem a melhor usinabilidade, finalmente o 21-2N é um material austenítico possuindo um grau de usinabilidade entre inconel e silcrome.

A composição química destes materiais é exibida na Tabela 6. Estes materiais vieram sem tratamento térmico doados pela empresa TRW após serem cortados por cisalhamento. 
Tabela 6 - Composição química do corpo de prova (\%).

\begin{tabular}{|c|c|c|c|}
\hline $\begin{array}{c}\text { Composição } \\
\text { Química }\end{array}$ & Inconel (751) & Silcrome 1 (VV45) & 21 - 2N (VV56) \\
\hline $\mathrm{C}$ & 0,10 Máx. & $0,40 / 0,50$ & $0,50 / 0,60$ \\
\hline $\mathrm{Mn}$ & 1,00 Máx. & 0,60 Máx. & $7,00 / 10,00$ \\
\hline $\mathrm{Si}$ & 0,50 Máx. & $2,70 / 3,30$ & 0,25 Máx. \\
\hline $\mathrm{Cr}$ & $14,00 / 17,00$ & $8,00 / 10,00$ & $19,50 / 22,00$ \\
\hline $\mathrm{Ni}$ & 70,00 Mín. & 0,30 Máx. & $1,50 / 2,75$ \\
\hline $\mathrm{S}$ & 0,01 Máx. & 0,030 Máx. & 0,030 Máx. \\
\hline $\mathrm{Fe}$ & $5,00 / 9,00$ & Restante & Restante \\
\hline $\mathrm{Al}$ & $0,90 / 1,50$ & & \\
\hline $\mathrm{Ti}$ & $2,00 / 2,60$ & & \\
\hline $\mathrm{Cu}$ & 0,50 Máx. & & 0,040 Máx. \\
\hline $\mathrm{Nb}+\mathrm{Ta}$ & $0,70 / 1,20$ & & 0,85 Mín. \\
\hline $\mathrm{P}$ & & 0,040 Máx. & $0,29 / 0,40$ \\
\hline $\mathrm{C}+\mathrm{N}$ & & & \\
\hline $\mathrm{N}$ & & & \\
\hline
\end{tabular}

Os corpos de prova possuem as seguintes dimensões: comprimento de $150 \mathrm{~mm}$, Inconel tem diâmetro de $28.5 \mathrm{~mm}$, Silcrome e 21-2N têm diâmetro de $25.5 \mathrm{~mm}$. As faces, superior e inferior, foram torneadas para eliminarem saliências e criar bom paralelismo. A Figura 3.8 mostra o corpo de prova depois de ensaio de retificação.

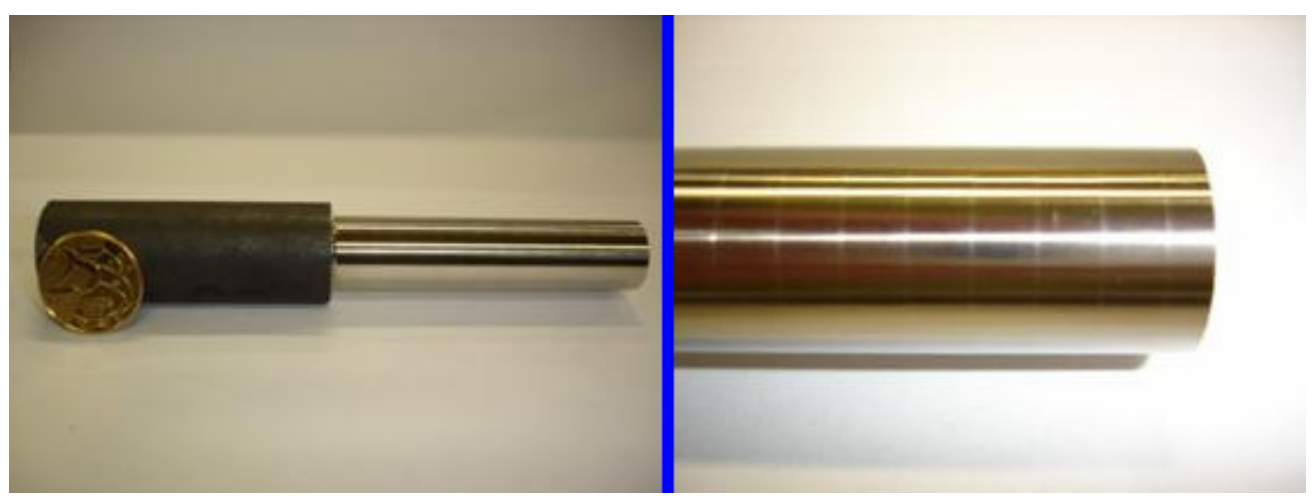

Figura 3.8 - Corpo de prova após ensaio de retificação. 


\subsection{Medição do desgaste radial do rebolo}

Para medir o desgaste radial do rebolo utilizaram-se dois métodos diferentes, sendo eles: (a) o mapa acústico e (b) a impressão do perfil desgastado.

(a) Medição de desgaste do rebolo através do mapa acústico:

Ao final do cada ensaio, o rebolo foi dressado com uma profundidade de dressagem de $1 \mu \mathrm{m}$, através do mapa acústico foi monitorada a topografia do rebolo, o desgaste total do rebolo é calculado através do número de passes de dressagem e profundidade de dressagem até a total limpeza da superfície do rebolo (Figura 3.9).

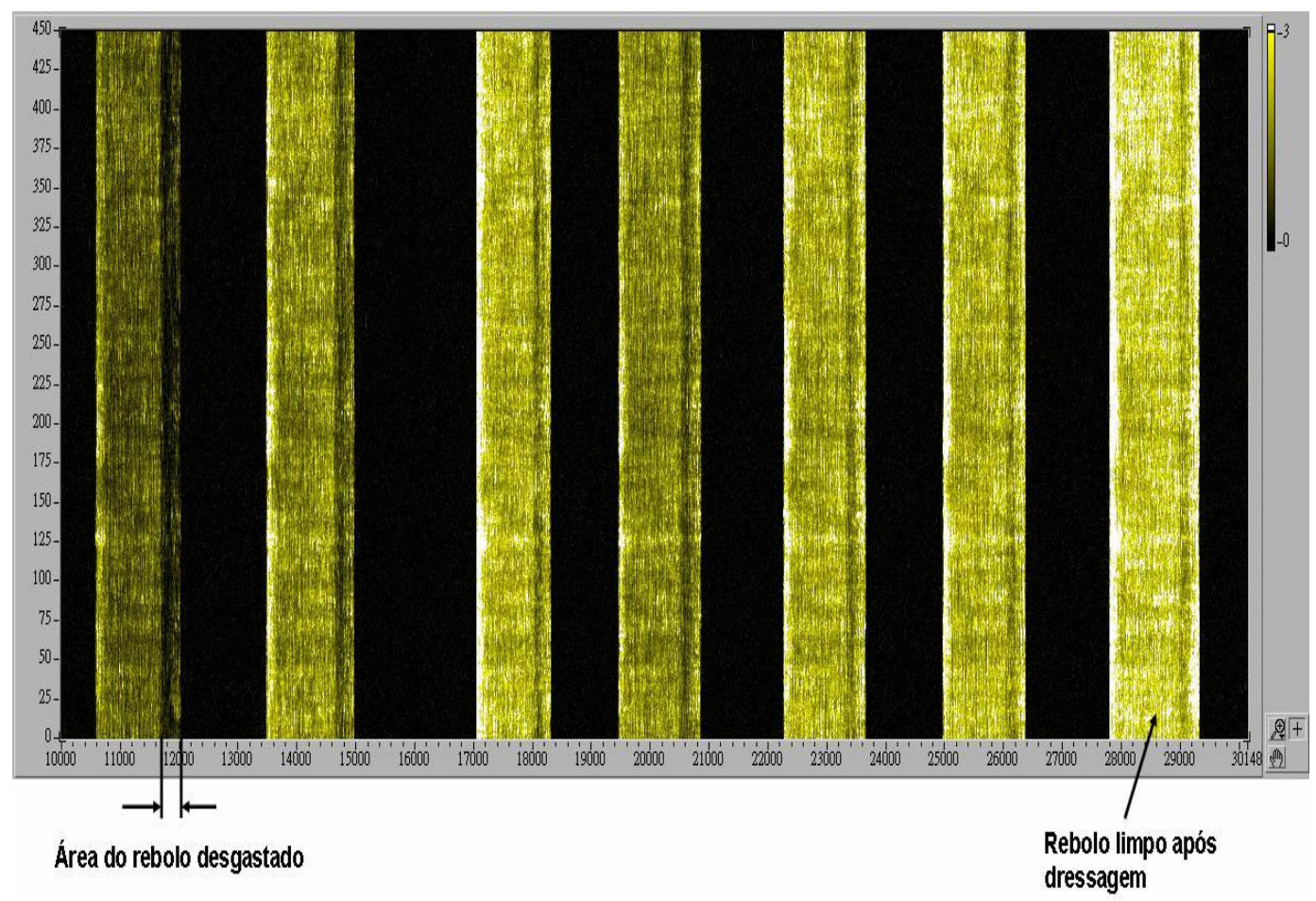

Figura 3.9 - Medição de desgaste do rebolo através do mapa acústica.

(b) Medição de desgaste do rebolo através da impressão do perfil desgastado:

Neste método, a cada $2000 \mathrm{~mm}^{3} / \mathrm{mm}$ foi realizada a impressão do perfil em um bloco de aço SAE 1020, de dimensões $69 \times 36 \times 10 \mathrm{~mm}$. O bloco foi fixado na base da contra-ponta da retificadora. $O$ rebolo então retificava um determinado volume de material, penetrando uma profundidade de corte igual a $5 \mathrm{~mm}$. Como 
durante o processo de retificação, apenas uma parte da largura do rebolo é desgastada, a outra serve de referência para a medição do desgaste radial $\Delta r$, a ser verificado. Este fica impresso no bloco, após o mergulho da ferramenta, conforme apresentado na Figura 3.10.

Deve-se ressaltar que foram obtidos os valores de desgaste radial utilizando o Form Talysurf 50 do fabricante TAYLOR HOBSON, calculou-se a média aritmética das 3 medições a cada $2000 \mathrm{~mm}^{3} / \mathrm{mm}$ volume específico de material removido.

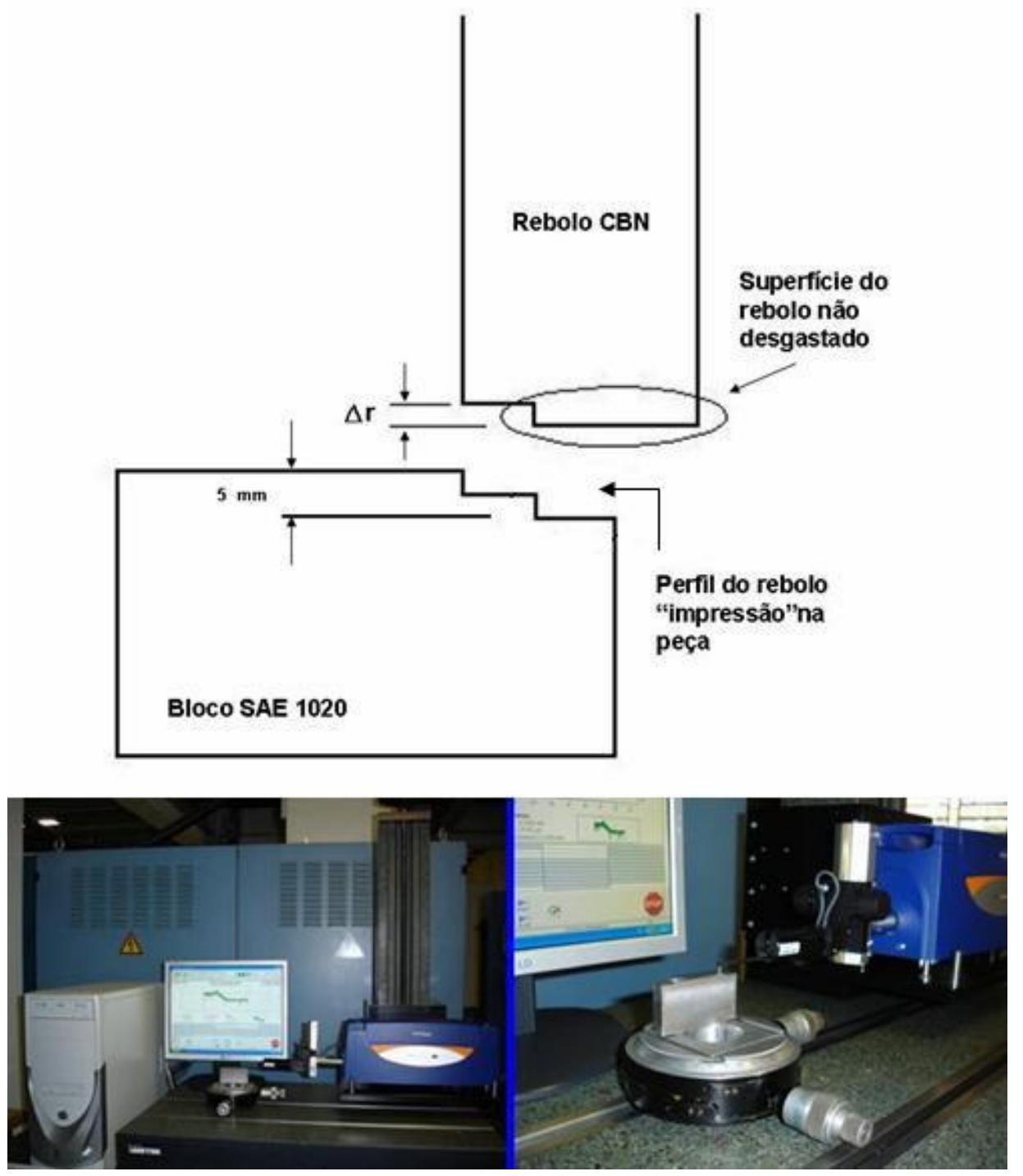

Figura 3.10 - Medição de desgaste pela impressão do perfil. 


\subsection{Planejamento dos experimentos}

Este trabalho é focado em avaliar a influência do avanço em relação ao desgaste do rebolo CBN na retificação de superligas e alguns parâmetros de saída: rugosidade, circularidade, potência, relação $\mathrm{G}$ e mapa de emissão acústica.

Os ensaios deste trabalho consistem na retificação de duas peças para cada uma das onze condições, num total de 22 peças retificadas.

Foram realizados onze ensaios de desgaste para rebolo de CBN de liga vitrificada, onde variou-se o material do corpo de prova e a velocidade de avanço na retificação. As condições de dressagem, a velocidade de corte e a rotação da peça foram mantidas constantes na retificação de mergulho. Em todos os ensaios, variou-se apenas a velocidade de avanço (Vf) e o material da peça. A Tabela 7 resume as condições em que os ensaios foram realizados.

Tabela 7 - Matriz experimental dos ensaios de desgaste.

\begin{tabular}{|c|c|c|c|c|c|}
\hline $\begin{array}{c}\text { Número de } \\
\text { Ensaio }\end{array}$ & $\begin{array}{c}\text { Material da } \\
\text { peça }\end{array}$ & $\mathbf{V s}[\mathbf{m} / \mathbf{s}]$ & $\mathbf{V w}[\mathbf{r p m}]$ & $\begin{array}{c}\mathbf{V f} \\
{[\mathbf{m m} / \mathbf{m i n}]}\end{array}$ & $\left.\mathbf{t}_{\mathbf{a}} \mathbf{s}\right]$ \\
\hline 1 & Inconel & 100 & 200 & 0,6 & 0,5 \\
\hline 2 & Inconel & 100 & 200 & 1,2 & 0,5 \\
\hline 3 & Inconel & 100 & 200 & 2,4 & 0,5 \\
\hline 4 & Inconel & 100 & 200 & 5,0 & 0,5 \\
\hline 5 & Silcrome & 100 & 200 & 1,2 & 0,5 \\
\hline 6 & Silcrome & 100 & 200 & 2,4 & 0,5 \\
\hline 7 & Silcrome & 100 & 200 & 5,0 & 0,5 \\
\hline 8 & $21-2 \mathrm{~N}$ & 100 & 200 & 0,6 & 0,5 \\
\hline 9 & $21-2 \mathrm{~N}$ & 100 & 200 & 1,2 & 0,5 \\
\hline 10 & $21-2 \mathrm{~N}$ & 100 & 200 & 2,4 & 0,5 \\
\hline 11 & $21-2 \mathrm{~N}$ & 100 & 200 & 5,0 & 0,5 \\
\hline
\end{tabular}

Foi utilizado $5 \mathrm{~mm}$ da largura do rebolo de CBN para retificar o corpo de prova, sendo que o restante da largura serviu como referência do rebolo não desgastado. Foram realizados 16 mergulhos em cada corpo de prova com um 
degrau de $0.03 \mathrm{~mm}$ entre eles. O volume específico de material removido foi de $250 \mathrm{~mm}^{3} / \mathrm{mm}$ em cada mergulho.

Os programas CNC utilizados para realizar tanto a dressagem do rebolo CBN como para efetuar a retificação estão descritos no ANEXO I. 


\section{RESULTADOS E DISCUSSÃO}

Neste capítulo são apresentados e discutidos os resultados obtidos nos ensaios realizados. Foi analisada, para efeito comparativo, a influência da velocidade de avanço (Vf) do rebolo $\mathrm{CBN}$ sobre a rugosidade, circularidade, potência, desgaste do rebolo e mapa de emissão acústica nos três materiais para fabricação da válvula do motor.

\subsection{Avaliação dos parâmetros de rugosidade}

A rugosidade superficial, Ra foi medida para cada condição na direção axial da peça. Os resultados são apresentados nas Figuras 4.1, 4.2 e 4.3.

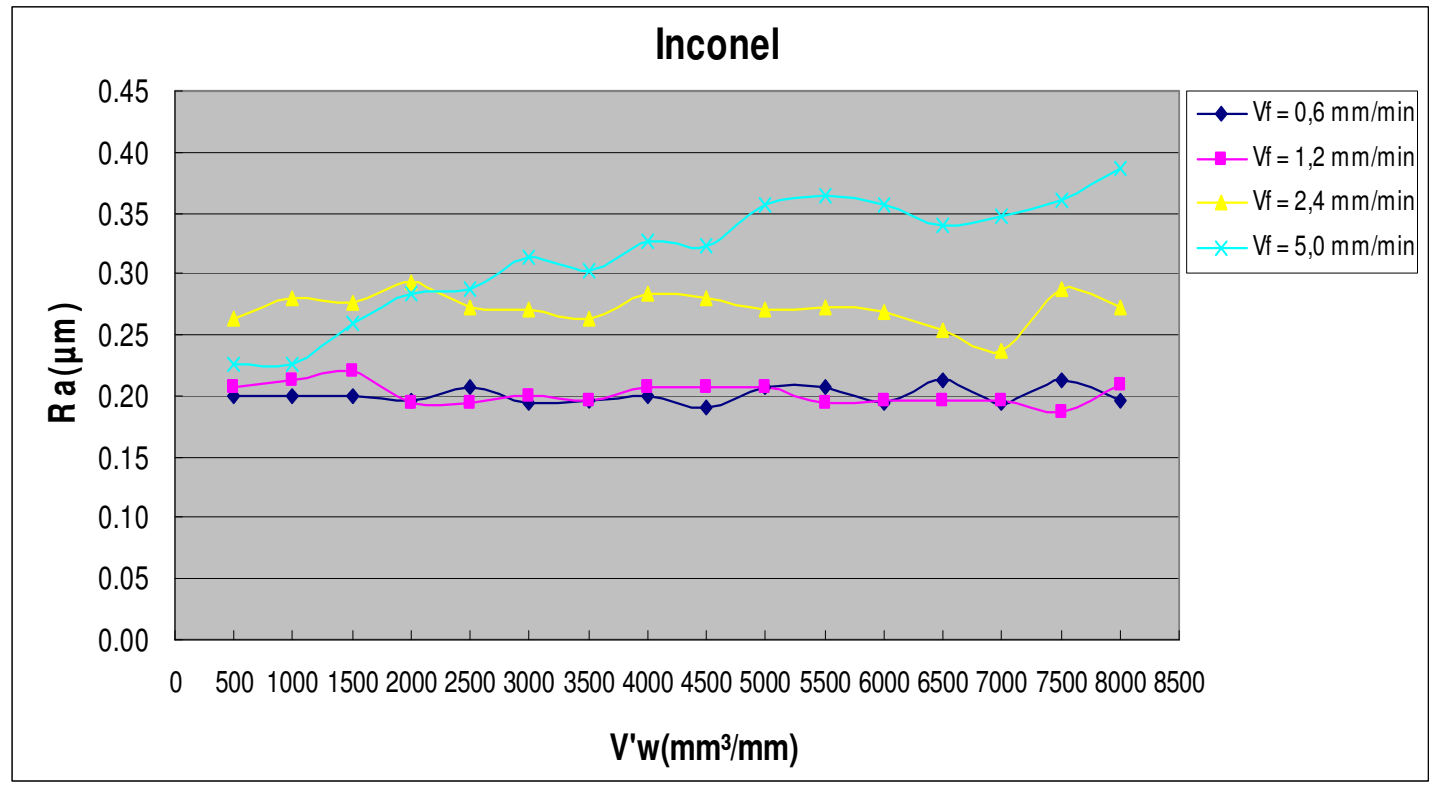

Figura 4.1 - Comportamento da rugosidade para o material Inconel em função do volume específico de material removido V'w. 


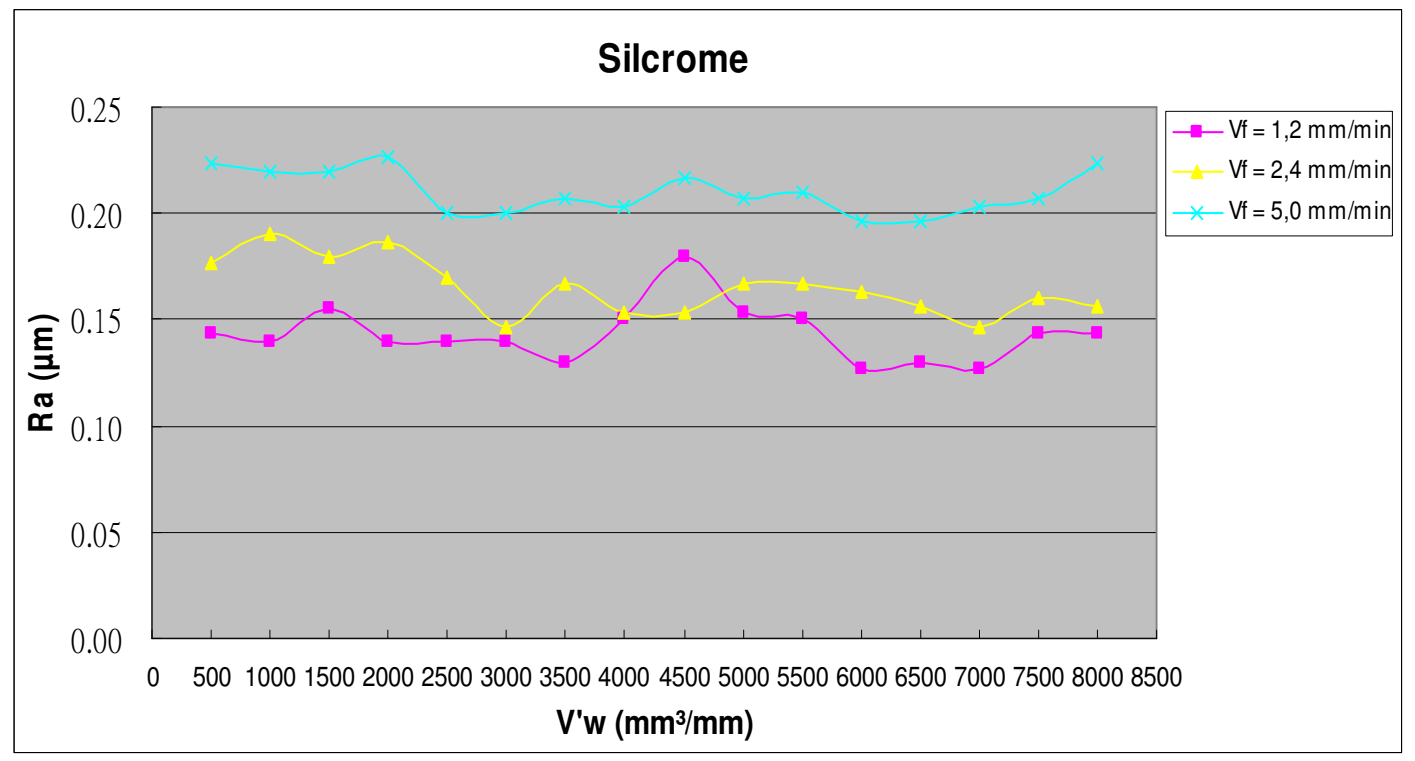

Figura 4.2 - Comportamento da rugosidade para o material Silcrome em função do volume específico de material removido V'w.

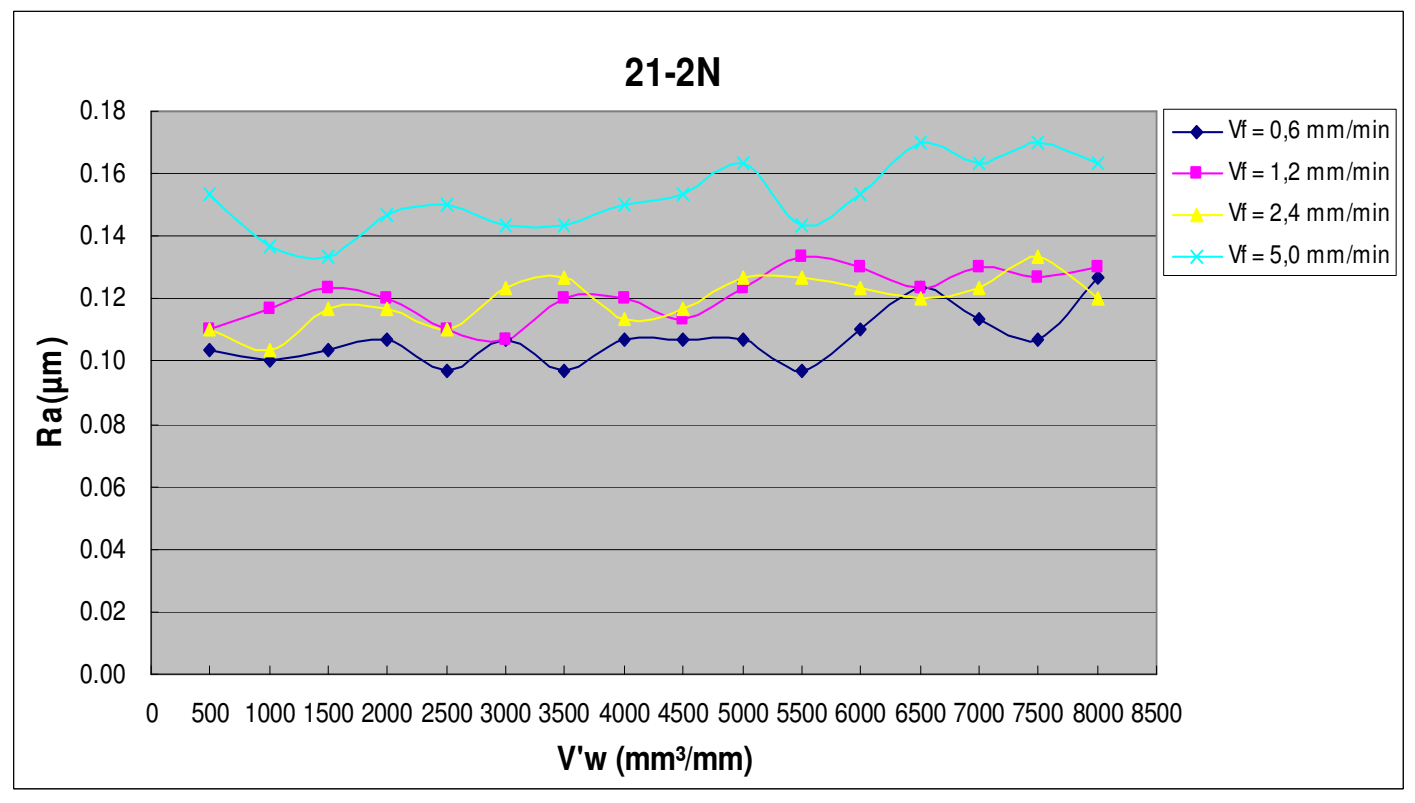

Figura 4.3 - Comportamento da rugosidade para o material 21-2N em função do volume específico de material removido V'w. 
A rugosidade de uma peça retificada é influenciada por diversos parâmetros, tais como: tamanho do grão abrasivo; condições de dressagem; taxa de remoção de material; tempo de centelhamento, lubri-refrigeração, entre outros fatores. Neste trabalho, apenas a velocidade de avanço (Vf) foi alterada, e desta forma, a taxa de remoção de material.

A variação da velocidade de avanço (Vf) do rebolo de $\mathrm{CBN}$ foi decisiva para os valores da rugosidade Ra. As Figuras 4.1 a 4.3 mostram que o aumento da velocidade de avanço (Vf) gera uma maior rugosidade na peça. Isto indica que os grãos abrasivos produzem sulcos com maior profundidade na peça para taxas de avanço (Vf) mais elevadas.

Também, observou-se que para condições mais severas nos materiais mais difíceis de retificar, ocorre um crescimento da rugosidade ao longo dos testes. Pode-se observar que este fenômeno não ocorre para Silcrome, ocorre pouco para $21-2 \mathrm{~N}$ e mais intensamente para o Inconel, devido às diferentes usinabilidade dos materiais de corpo de prova. Constata-se que materiais com pior usinabilidade produzem modificações na topografia do rebolo que acarreta em aumento de rugosidade. Portanto, espera-se que em tais condições mais severas o desgaste do rebolo seja mais acentuado.

\subsection{Circularidade}

O erro de circularidade é um valor de extrema importância para o processo de retificação cilíndrica e deve estar de acordo com a tolerância especificada no projeto. Este erro está diretamente relacionado às condições de retificação adotadas e às perturbações da máquina e do sistema de fixação da peça.

A Figura 4.4 apresenta a análise de circularidade do Inconel retificado com velocidade de avanço de $5 \mathrm{~mm} / \mathrm{min}$, foi gerado pelo aparelho TALYROND 131 TAYLOR HOBSON. Os gráficos obtidos têm características comuns e são similares ao exemplo mostrado na Figura 4.4. Observa-se que os fenômenos relacionados à circularidade não têm boa relação com as condições de usinagem, mas, mais predominantemente, com o sistema de fixação utilizado. Por exemplo, na retificação entre centros há uma influência muito grande da qualidade do furo de centro na circularidade. Tal fato pode explicar a uniformidade no valor de 
circularidade para uma mesma peça (e portanto com o mesmo furo de centro) ser mais constante. Também, a furação do Silcrome deve resultar em melhor qualidade do furo de centro. De qualquer forma, não há muito que concluir sobre a influência das condições de retificação em relação à circularidade obtida. Devese finalmente ressaltar que os valores obtidos são bons e compatíveis com as tolerâncias de produtos que utilizam tais materiais, a Figura 4.5 apresenta um exemplo de especificação de forma e acabamento em duas regiões importantes de válvulas.

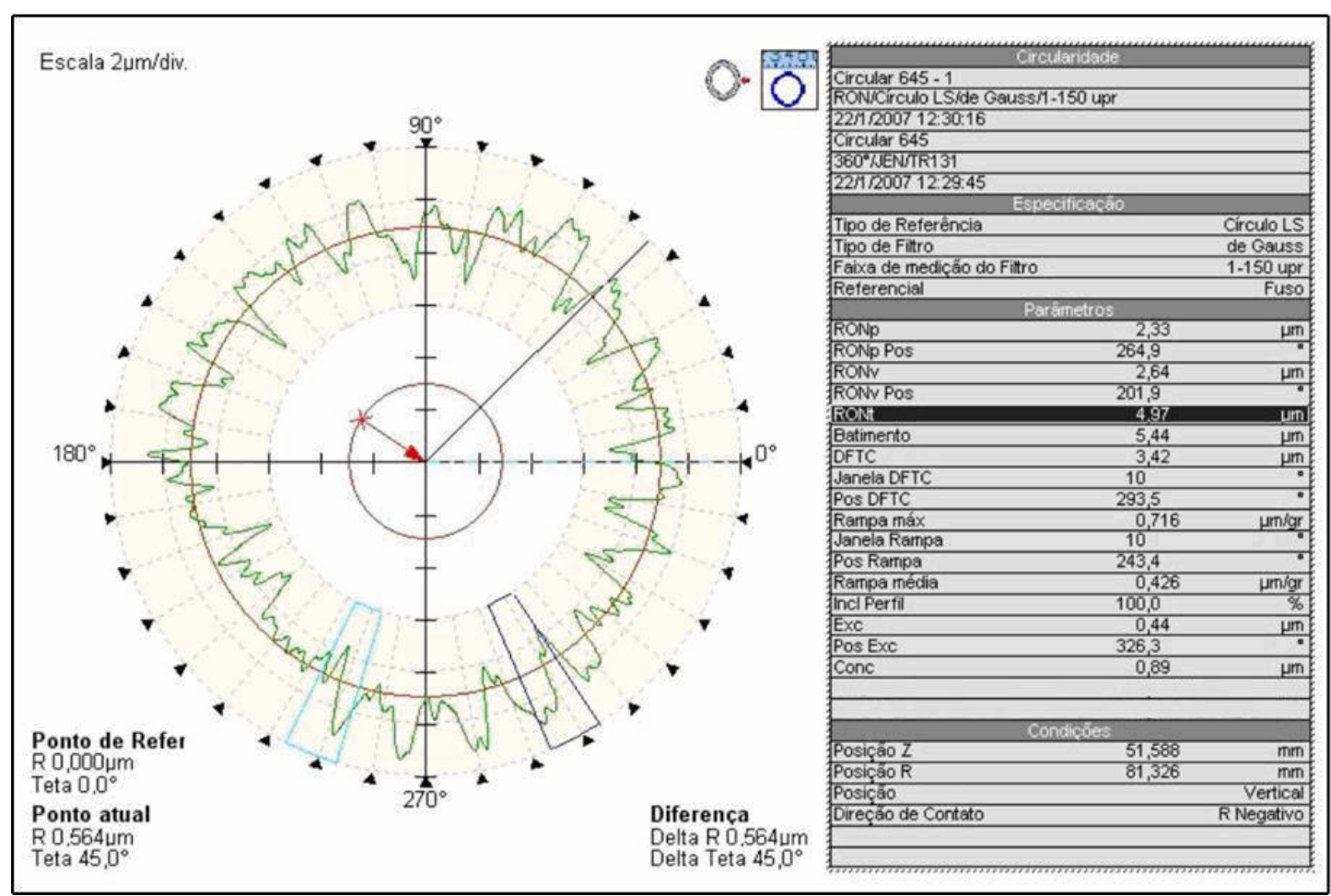

Figura 4.4 - Análise de circularidade do Inconel retificado com velocidade de avanço de $5 \mathrm{~mm} / \mathrm{min}$. 


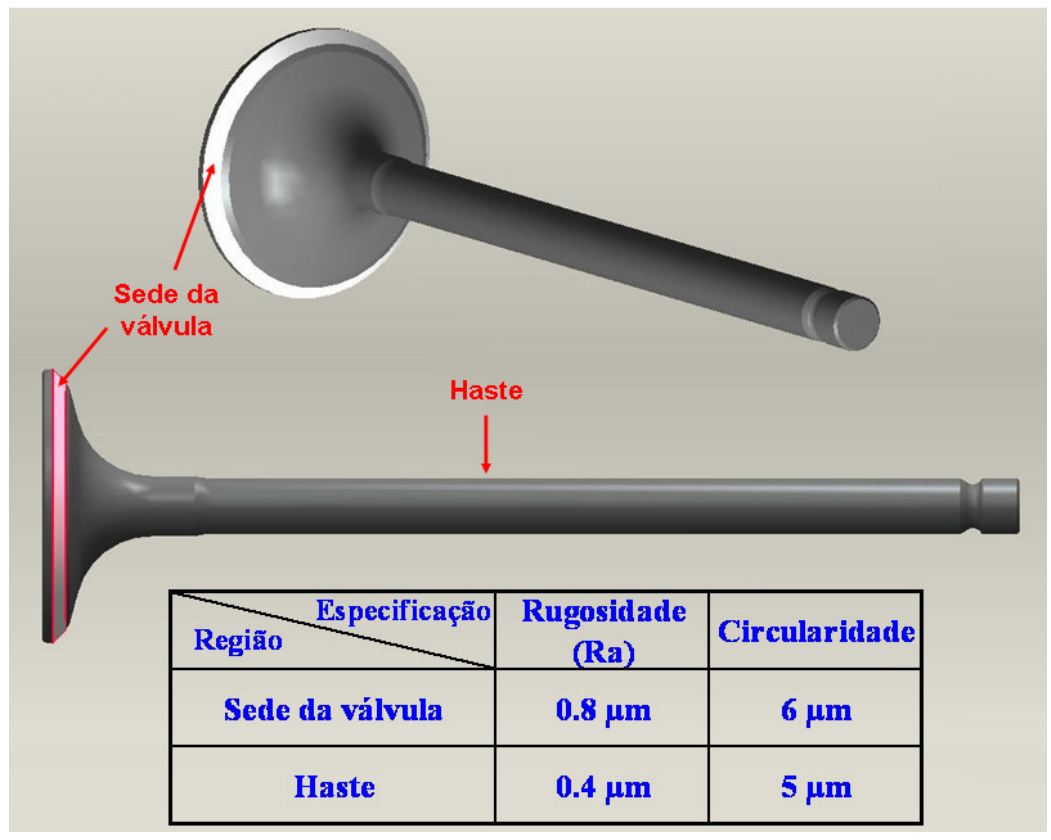

Figura 4.5 - Exemplo de especificação de forma e acabamento em duas regiões importantes de válvulas.

As Figuras 4.6, 4.7 e 4.8 representam uma comparação entre os valores médios do erro de circularidade $(\mu \mathrm{m})$ para todas as velocidades de avanço $(\mathrm{Vf})$.

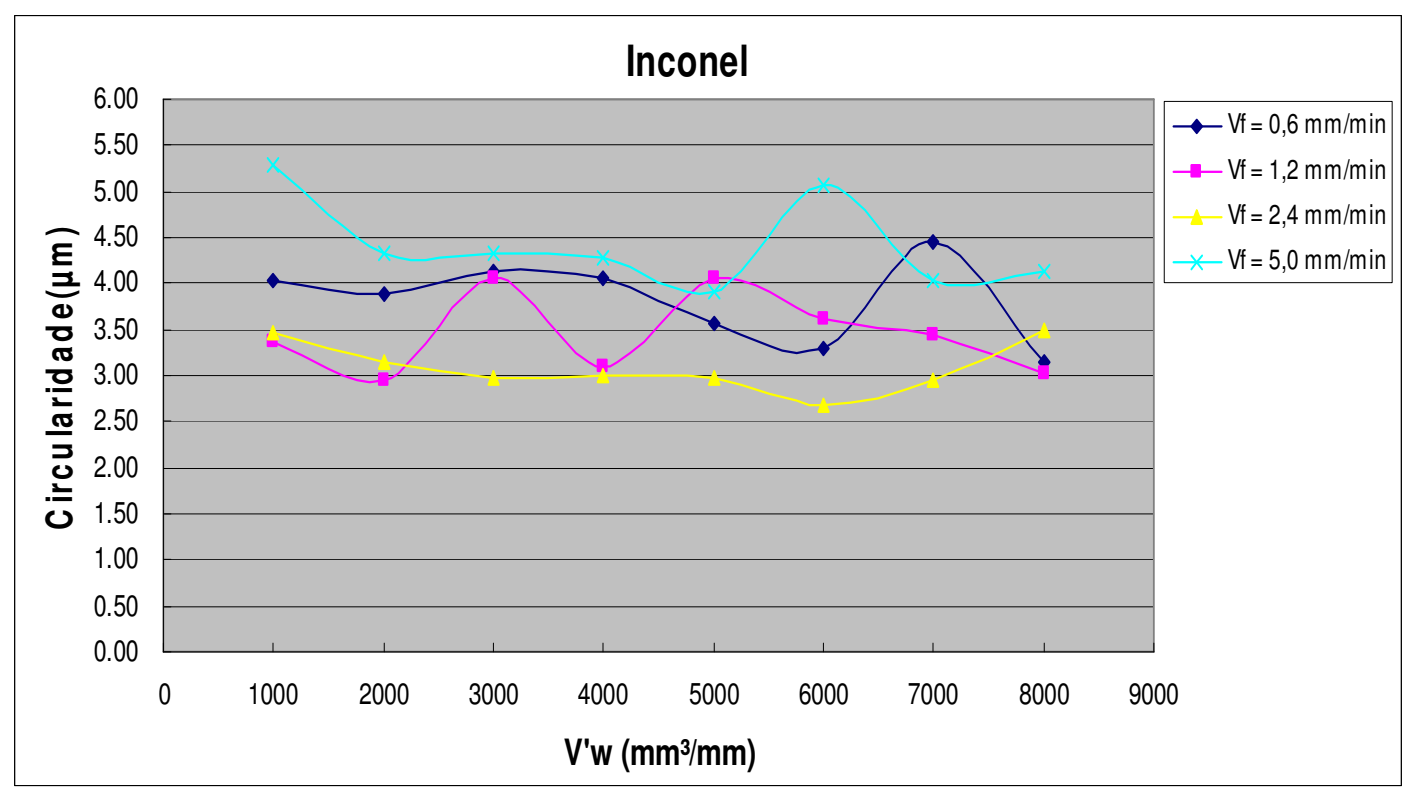

Figura 4.6 - Comportamento da circularidade para o material Inconel em função do volume específico de material removido V'w. 


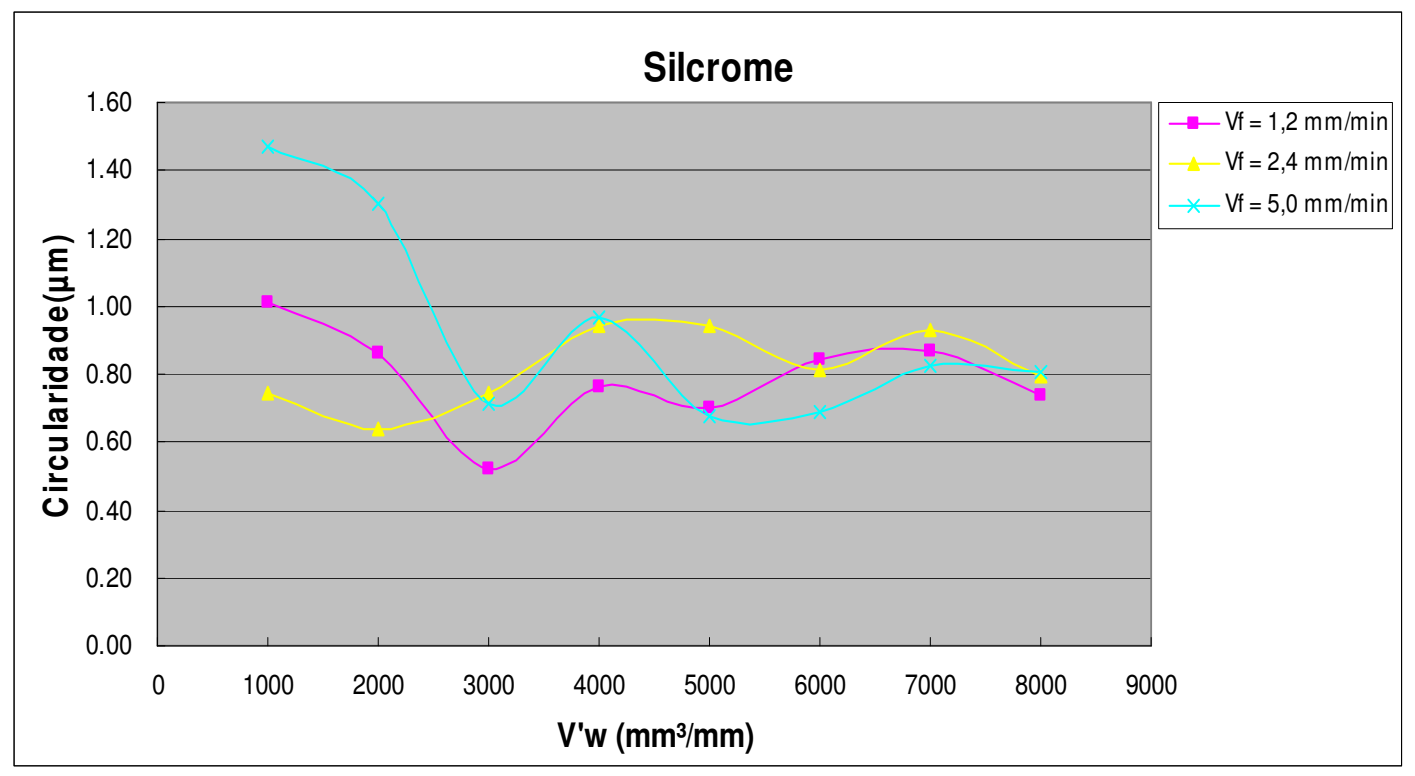

Figura 4.7 - Comportamento da circularidade para o material Silcrome em função do volume específico de material removido V'w.

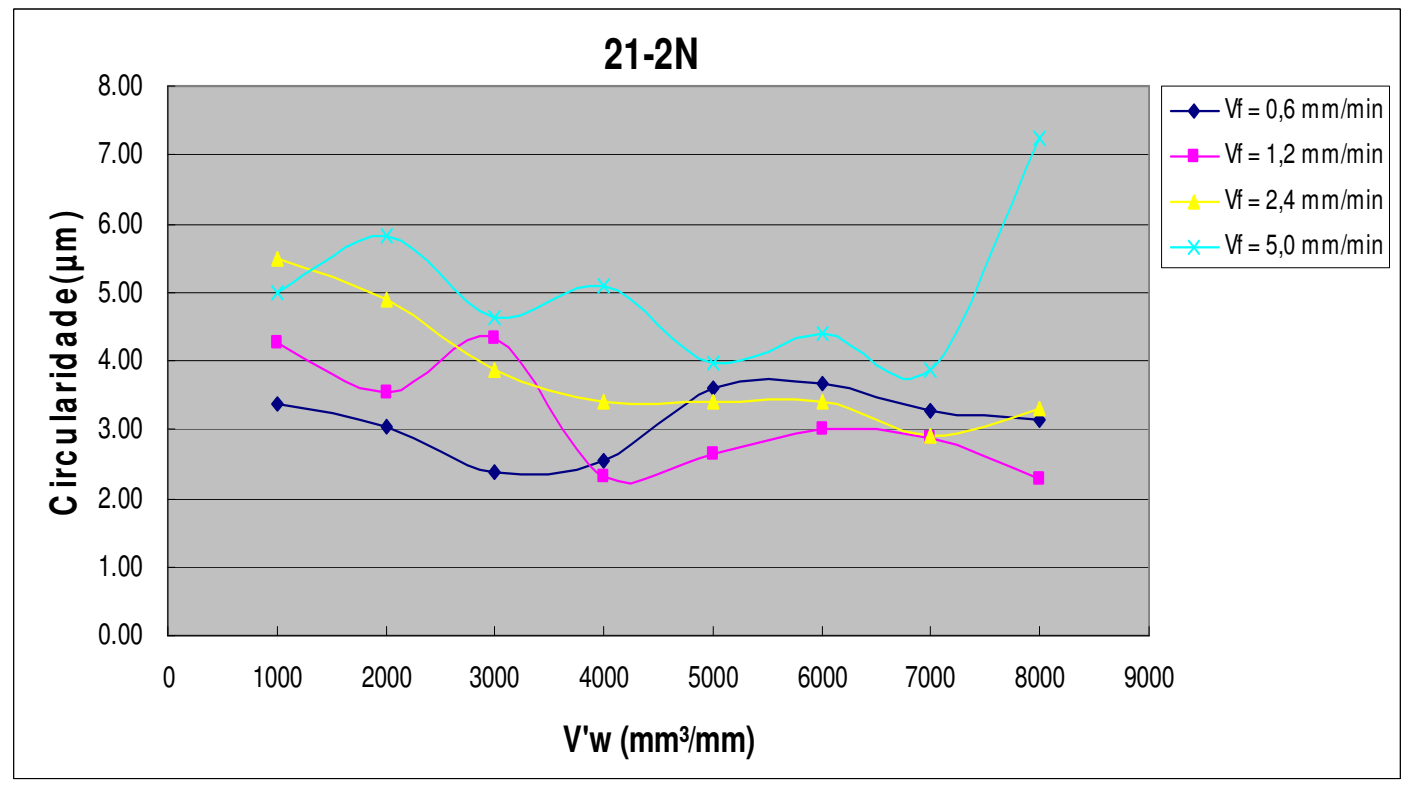

Figura 4.8 - Comportamento da circularidade para o material 21-2N em função do volume específico de material removido V'w. 
Como pode ser visto nas Figuras 4.6 a 4.8 existe uma tendência dos valores de circularidade estabilizarem-se ao longo do ensaio, porém não é muito significativo.

O erro de circularidade é o valor referente ao erro geométrico que pode ser causado pelo mau assentamento do tarugo do corpo de prova sobre as castanhas da placa, ou sofrer influência de outros fatores como: má refrigeração na retificação, desbalanceamento do rebolo, erros geométricos do rebolo e vibrações.

Não se pode concluir muito sobre os gráficos de circularidade, pois estão sujeitos a muitas influências. Por outro lado, percebe-se que para a usinagem do Silcrome (material de melhor usinabilidade) os valores de rugosidade obtidos são muito menores. Pode-se explicar esse fato pelas menores forças (e conseqüentemente, menores deformações) existentes no processo para a retificação de materiais de fácil usinabilidade.

\subsection{Potência consumida}

As Figuras 4.9 a 4.11 mostram os valores experimentais da potência em função do volume específico de material removido, obtidos a partir de valores preestabelecidos da velocidade de avanço (Vf), durante do processo de retificação. Estes dados são de grande importância na avaliação dos mecanismos de corte e como confirmação das hipóteses formuladas nos itens anteriores.

De acordo com estas figuras, conclui-se que quanto maior for a velocidade de avanço $(\mathrm{Vf})$, maior será a potência consumida no processo de retificação.

Quando ocorre o aumento da velocidade de mergulho do rebolo em direção à peça, ocorre também uma maior resistência ao movimento de rotação do rebolo devido aos maiores valores de deformação envolvidos no processo de corte. Esta resistência gera um aumento da potência elétrica consumida pelo motor de acionamento da ferramenta que, por sua vez, gera um aumento da potência mecânica. 


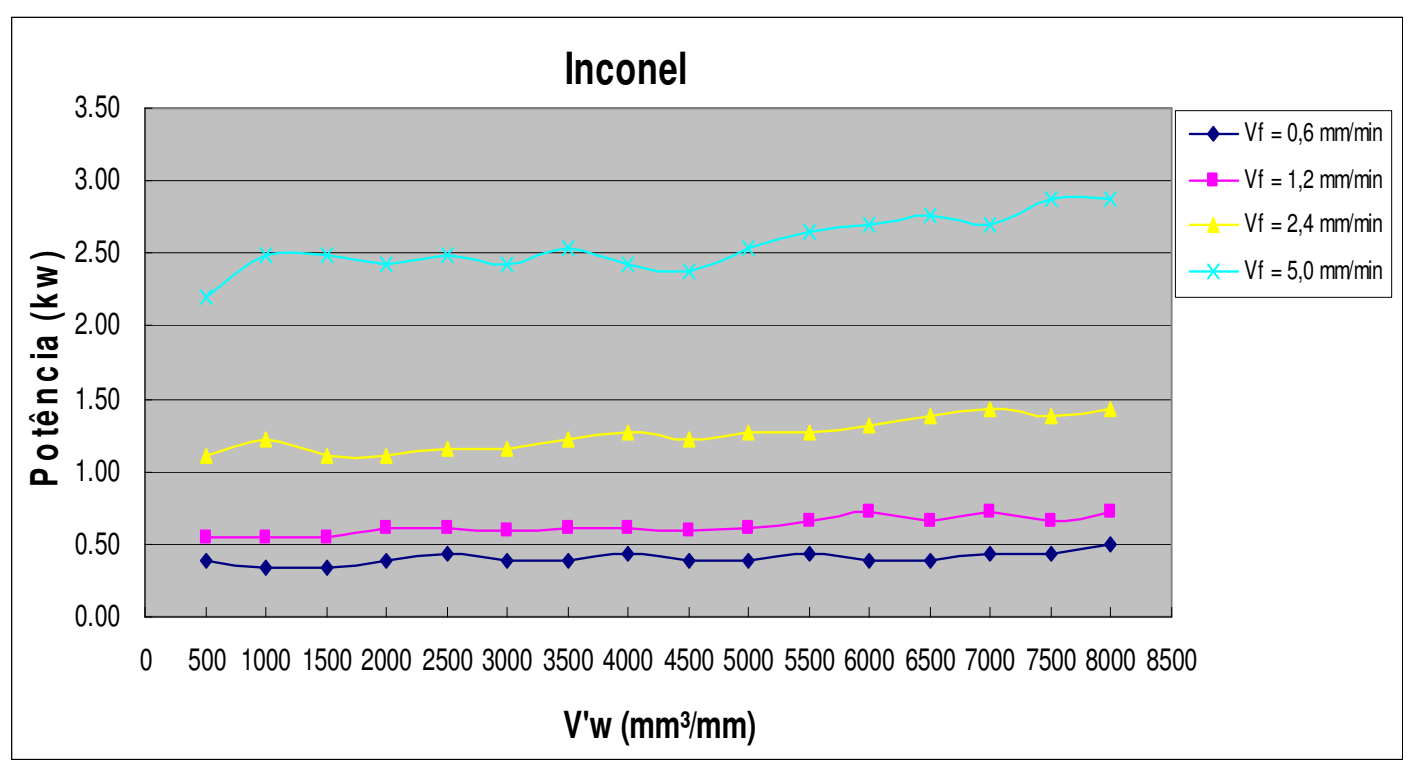

Figura 4.9 - Comportamento da potência para o material Inconel em função do volume específico de material removido V'w.

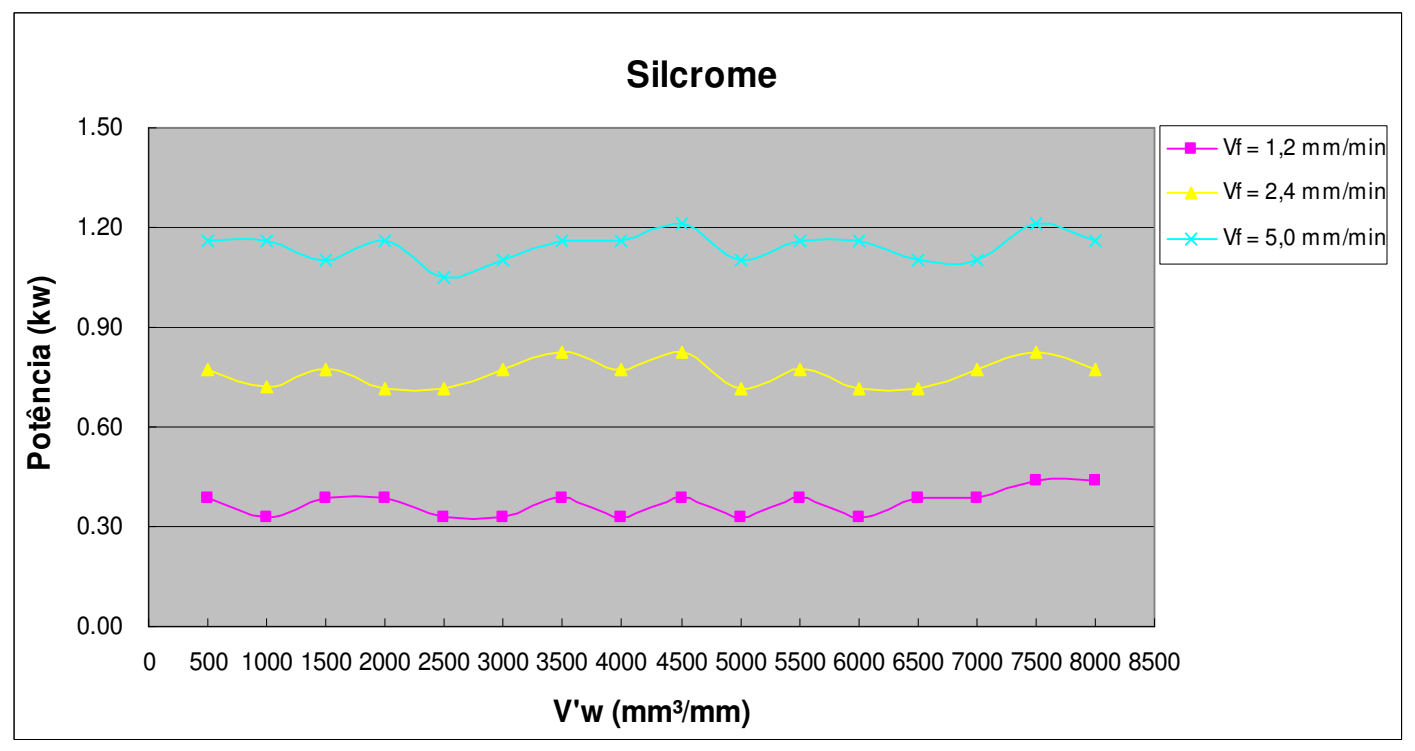

Figura 4.10 - Comportamento da potência para o material Silcrome em função do volume específico de material removido V'w. 


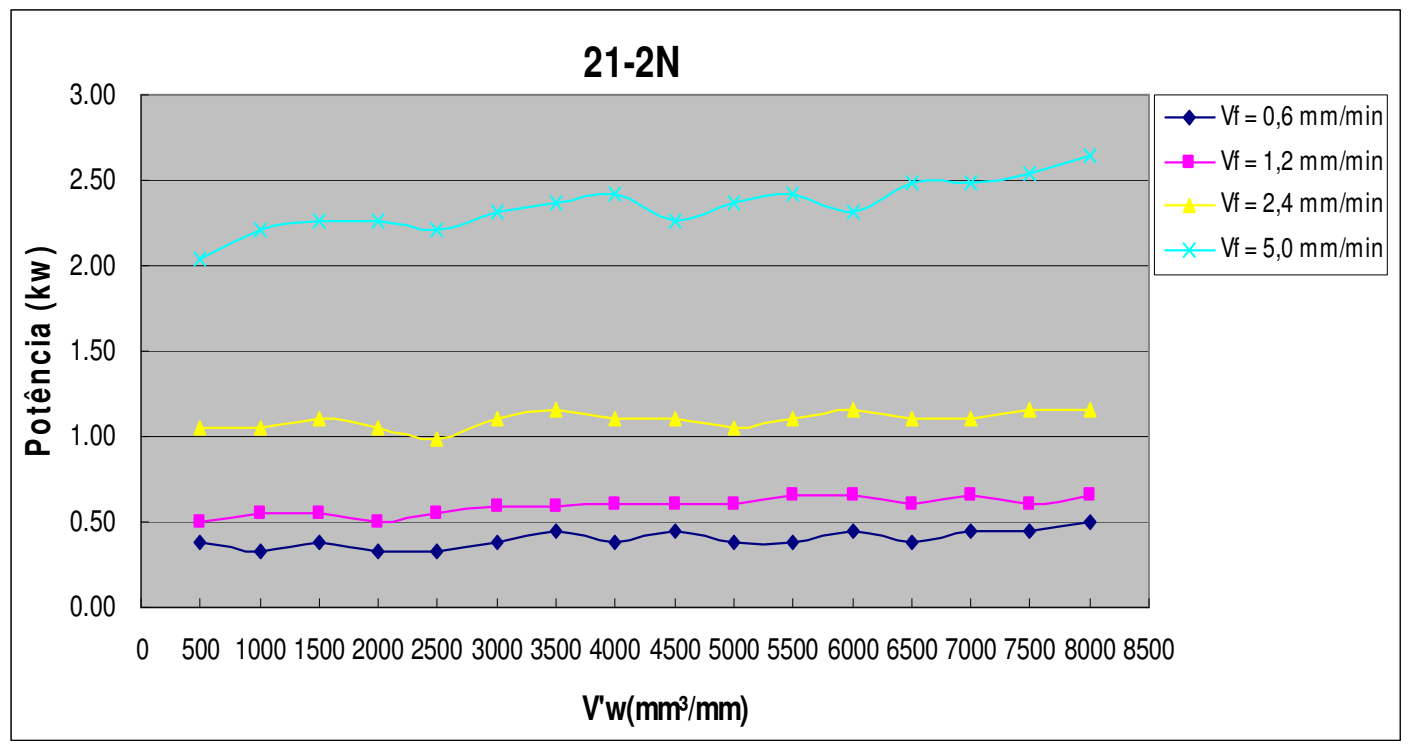

Figura 4.11 - Comportamento da potência para o material 21-2N em função do volume específico de material removido V'w.

Pode-se observar também um leve crescimento da potência com o aumento do volume de material retificado para materiais de difícil formação de cavaco, como o Inconel e 21-2N, em condições mais severas de retificação. Há de se destacar a coincidência entre as condições nas quais a potência e a rugosidade crescem. Isso comprova a hipótese de que nas condições mais severas, o rebolo sofre transformações topográficas. Provavelmente ocorre um entupimento de porosidades do rebolo.

Comparando a potência consumida entre os materiais na mesma condição de retificação, o Inconel apresenta os maiores valores de potência consumida no processo por possuírem pior usinabilidade, já o Silcrome possui menor valor de potência consumida e o 21-2N possui valores de potência consumida entre os dois materiais.

\subsection{Desgaste do rebolo}

As Figuras 4.12, 4.13 e 4.14 apresentam valores médios do desgaste radial do rebolo $(\mu \mathrm{m})$ para todas as velocidades de avanço (Vf) utilizadas. 


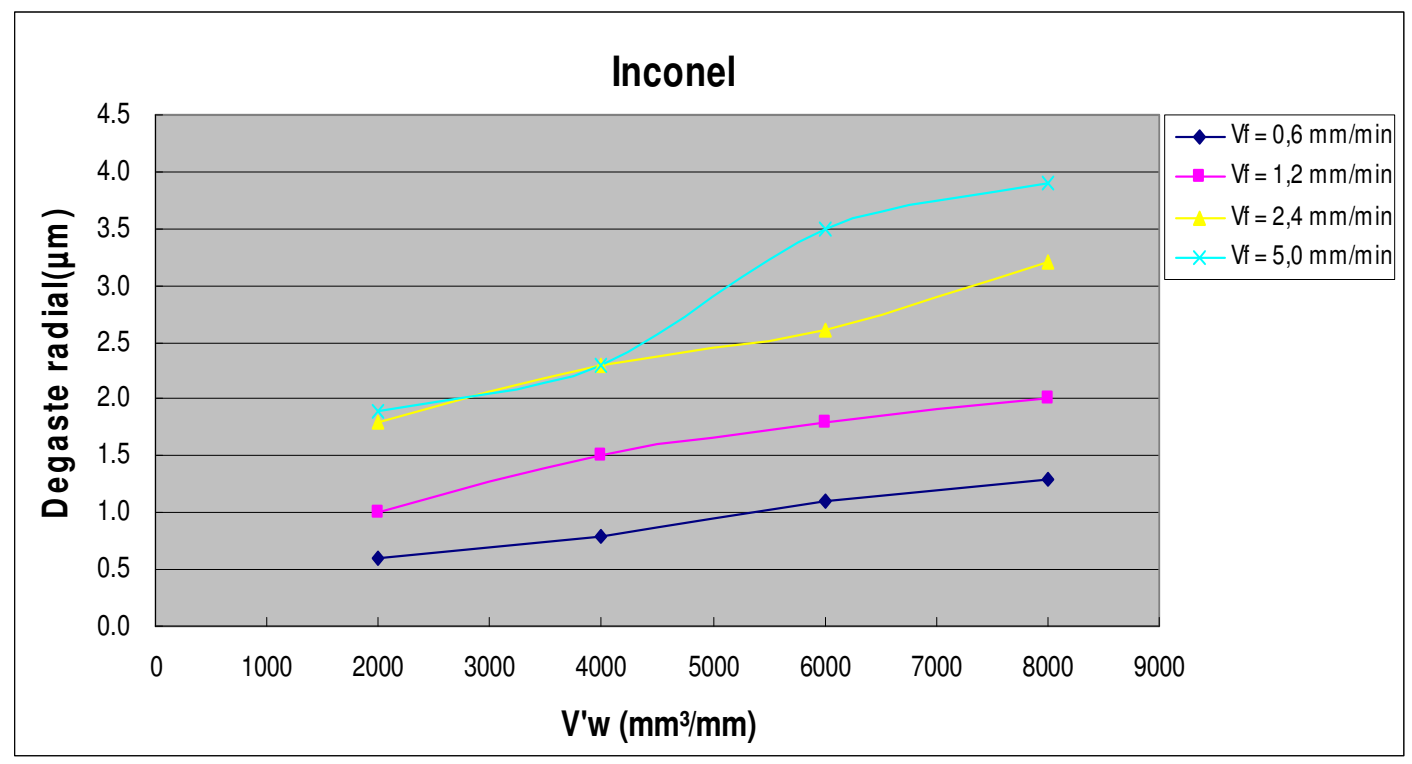

Figura 4.12 - Comportamento do desgaste radial para o material Inconel em função do volume específico de material removido V'w.

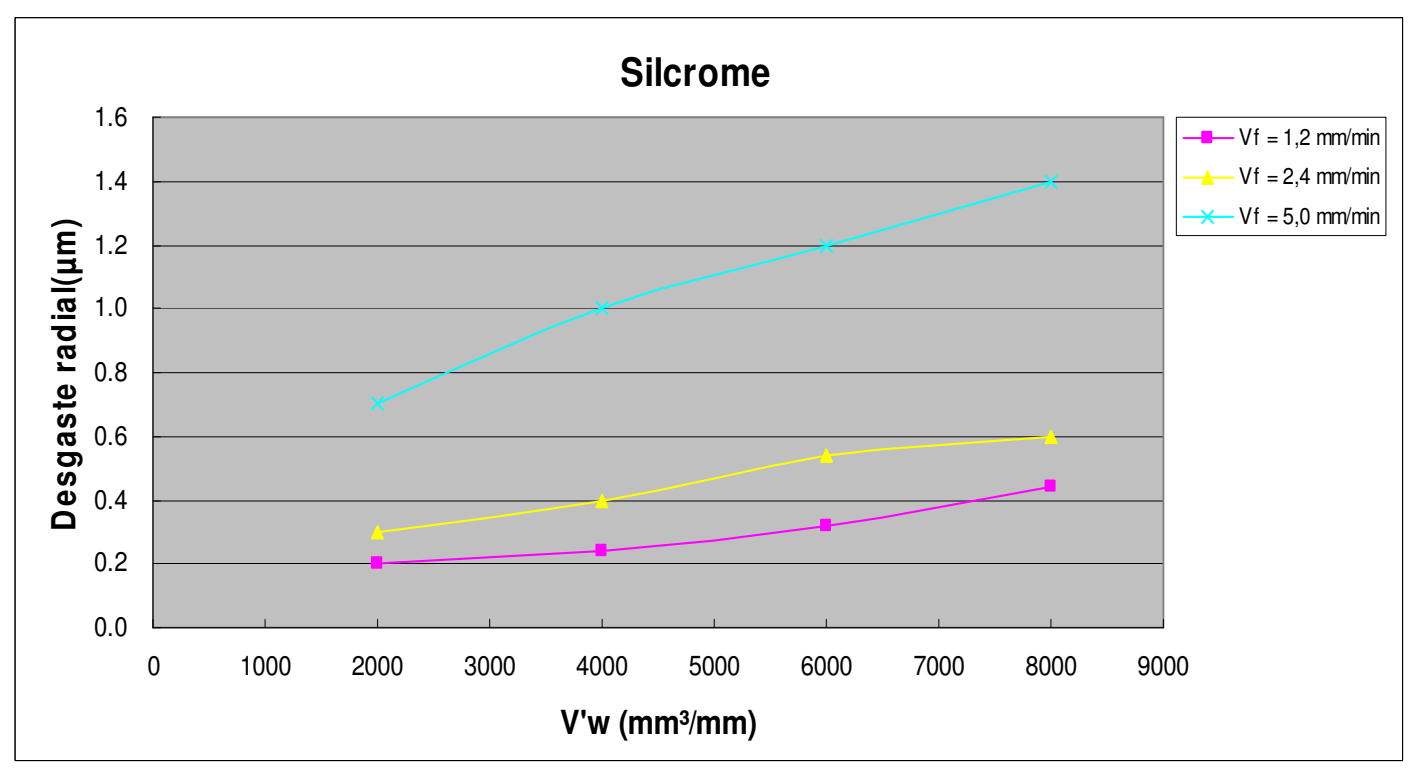

Figura 4.13 - Comportamento do desgaste radial para o material Silcrome em função do volume específico de material removido V'w. 


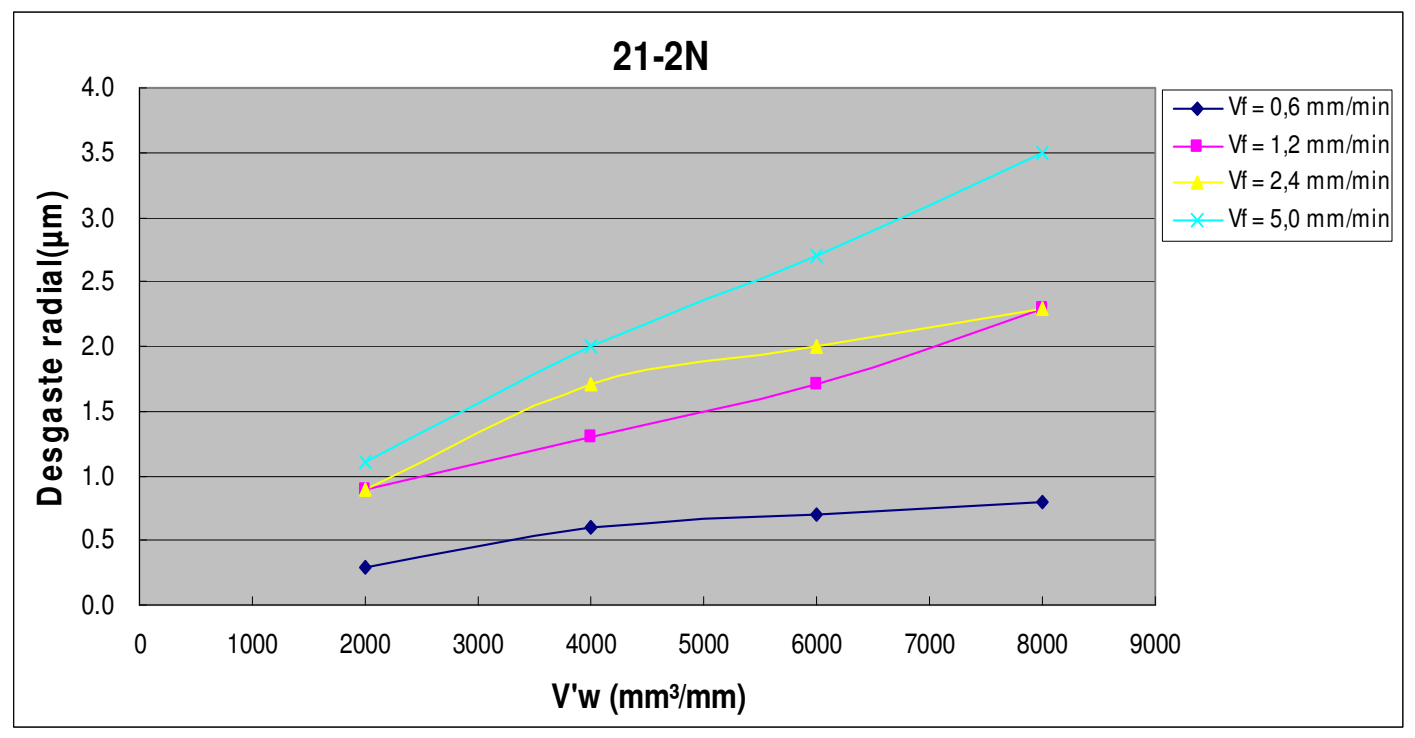

Figura 4.14 - Comportamento do desgaste radial para o material 21-2N em função do volume específico de material removido V'w.

Os valores de desgaste do rebolo foram obtidos através da impressão do perfil desgastado. Neste método, os valores são menores comparando-se com os resultados obtidos através de método de emissão acústica. Isto devido ao fato do desgaste do rebolo ser irregular e o método da emissão acústica considerar o rebolo corrigido após a eliminação de todas as falhas circunferenciais, o que exige mais remoção de material. Optou-se pelo método da impressão, nesse caso, porque permite monitorar o desgaste durante todo o processo. $O$ método da emissão acústica envolve dressagem do rebolo e não permite acompanhamento do desgaste. O método da emissão acústica, de qualquer forma, foi útil para verificar se havia consistência no valor total desgastado. Os valores obtidos pelo método acústico foram usados para se calcular a relação $G$ de retificação, discutida mais adiante.

A Figura 4.15 mostra um exemplo de mapa acústico, onde foram efetuados 6 passes de 0.5 micros de dressagem para se corrigir a superfície do rebolo na retificação do material $21-2 \mathrm{~N}$, com velocidade de avanço $2.4 \mathrm{~mm} / \mathrm{min}$. Isso indica um valor total de 3.0 microns. Tal desgaste medido pelo método da impressão foi de 2.3 microns. 


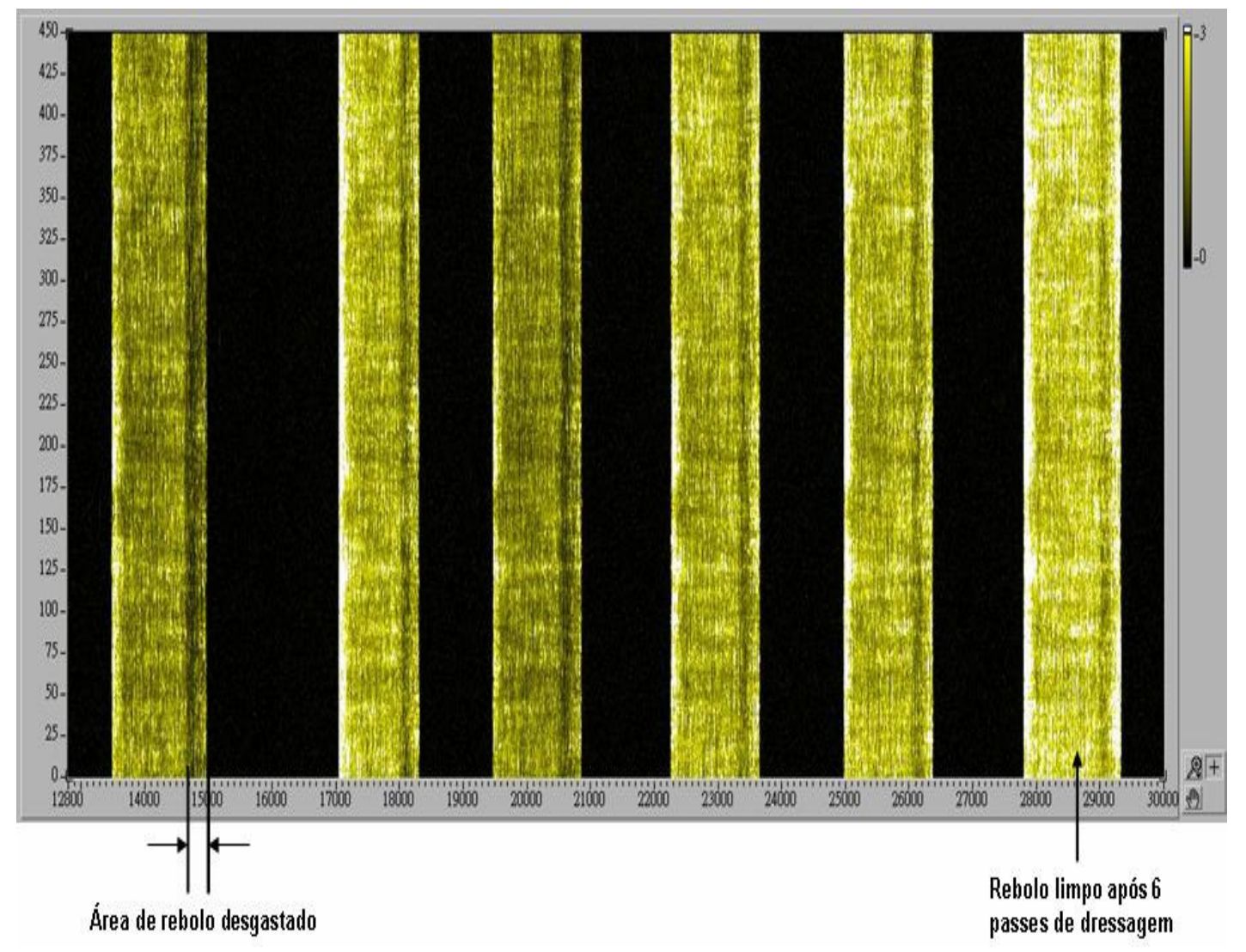

Figura 4.15 - Mapa acústico de dressagem com 6 passes de 0.5 microns.

Observando as Figuras 4.12 a 4.14, nota-se que o valor do desgaste radial do rebolo tende a aumentar com a velocidade de avanço (Vf), isto se dá pelo aumento da carga nos grãos abrasivos, podendo resultar nos mecanismos tradicionais de desgaste volumétrico do rebolo: trincas e quebra do ligante e conseqüente perda de grão abrasivo do rebolo. Quanto maior a velocidade de avanço (Vf) maior será o desgaste radial do rebolo.

Pelas figuras fica também evidente a relação da taxa de desgaste com a velocidade de avanço. Pode-se observar uma maior inclinação das curvas para altas velocidades. Isto significa que a taxa de desgaste do rebolo aumenta com o aumento da velocidade de avanço.

Destaca-se que o aumento de potência consumida, combinado com o desgaste volumétrico medido, indica que ambos fenômenos (entupimento de porosidades e perda de grãos) ocorrem simultaneamente. Pode-se também concluir que a composição do corpo de prova tem grande influência no desgaste e 
entupimento da superfície do rebolo, bem como na qualidade superficial da peça. De acordo com os gráficos, quanto pior a usinabilidade do material, maior será desgaste do rebolo, neste caso o Inconel.

\subsection{Relação G}

A partir dos ensaios de desgaste do rebolo CBN vitrificado foram calculadas as relações entre o volume de material retificado e o volume de rebolo desgastado (Equação 7). Esses resultados são apresentados nas Figuras 4.16, 4.17 e 4.18.

$$
\mathrm{G}=\frac{V^{\prime} w}{V^{\prime} s}
$$

Os valores de cálculos de desgaste do rebolo CBN são baseados nos métodos de mapa acústico que é mais aplicado nas indústrias automotivas.

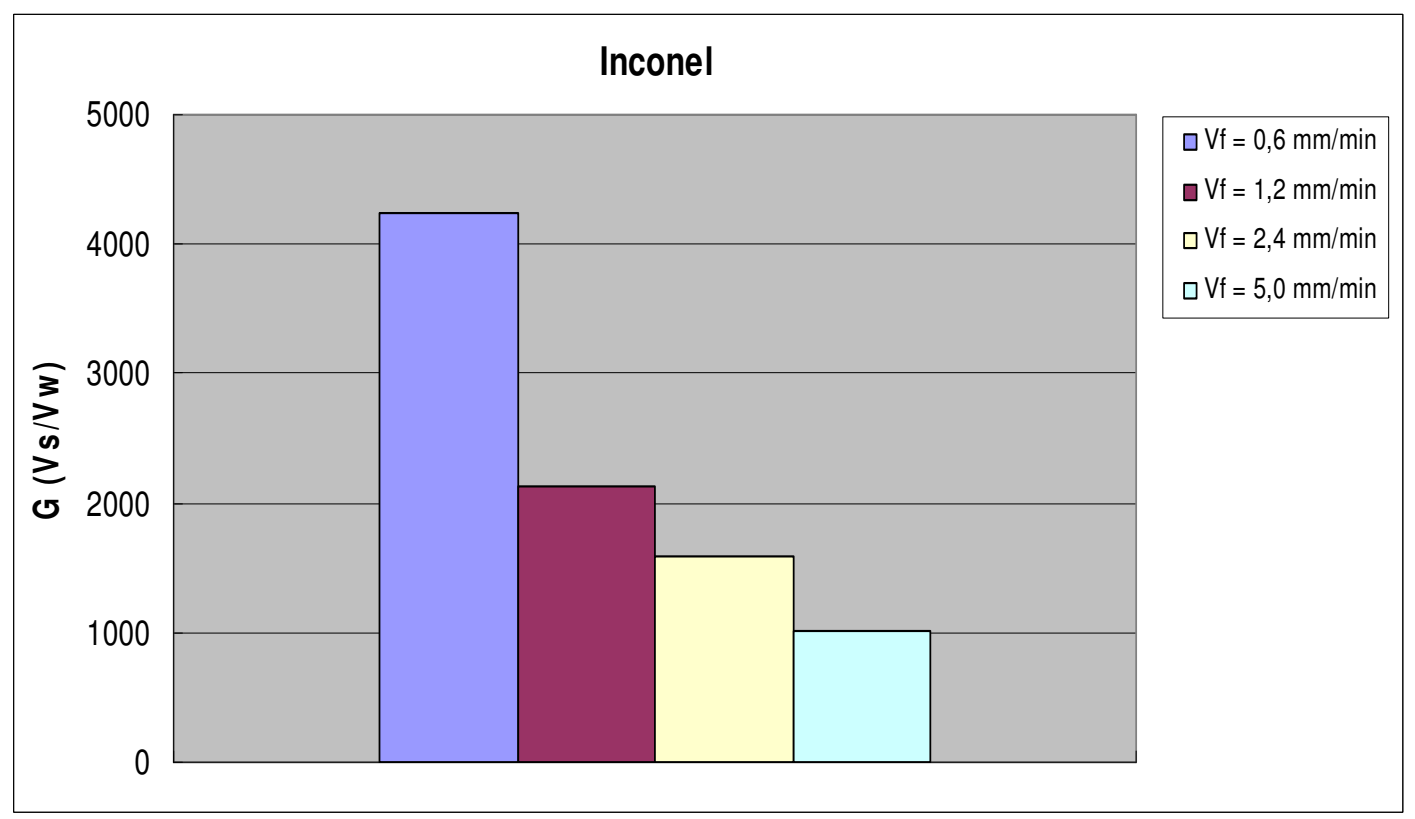

Figura 4.16 - Comparação dos valores de $\mathrm{G}$ em diferentes velocidades de avanço (Vf) na retificação de Inconel. 


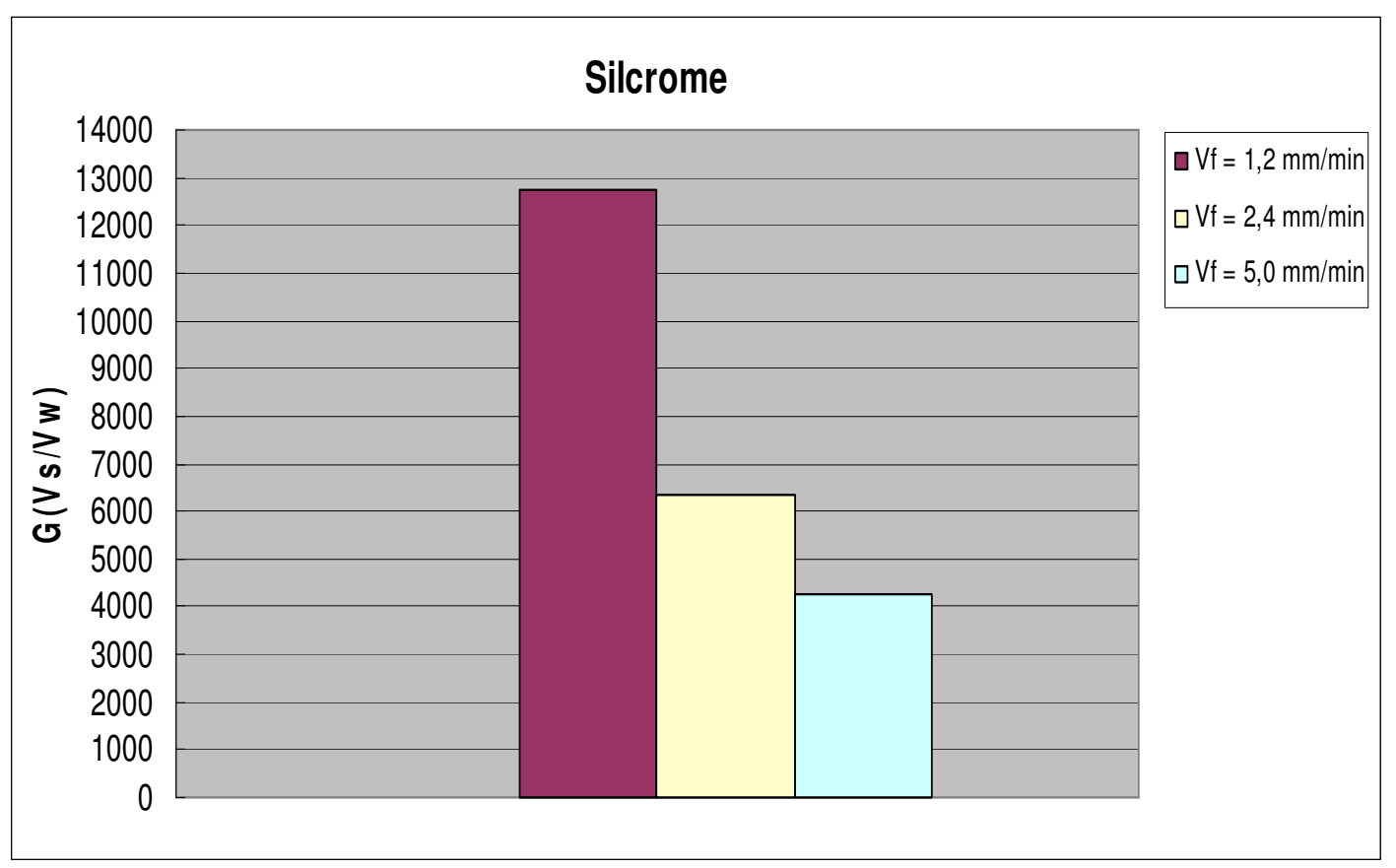

Figura 4.17 - Comparação dos valores de G em diferentes velocidades de avanço (Vf) na retificação de Silcrome.

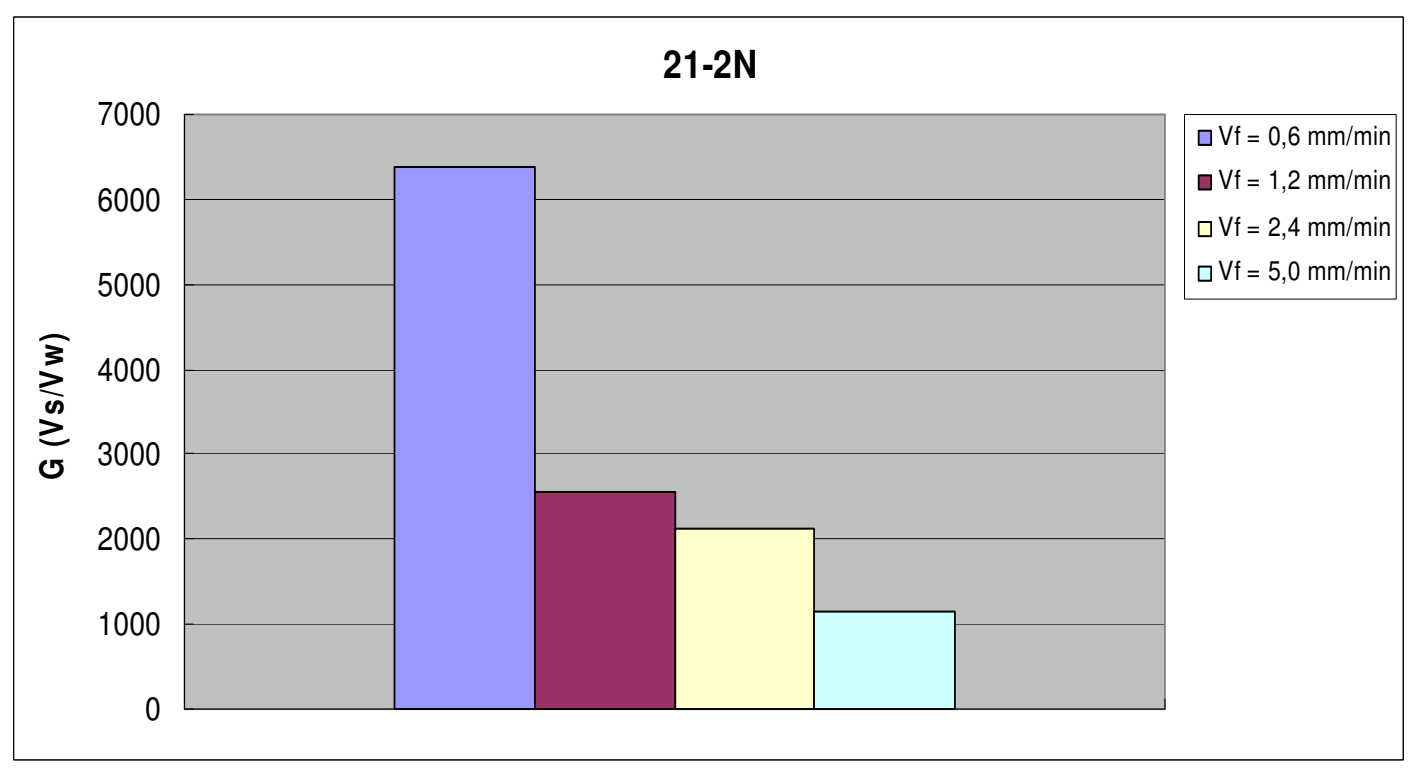

Figura 4.18 - Comparação dos valores de $\mathrm{G}$ em diferentes velocidades de avanço (Vf) na retificação de 21-2N.

Observando-se as figuras apresentadas, tanto o tipo do material retificado quanto o valor da velocidade de avanço utilizada no ciclo de retificação 
apresentam importante papel na vida útil do rebolo. Analisando o resultado do parâmetro $G$, em relação à retificação de cada material com as diferentes velocidades de avanço (Vf), conclui-se que quanto maior é a velocidade de avanço maior é o desgaste do rebolo.

De qualquer forma, materiais com pior usinabilidade geram maiores forças por grão abrasivo, o que deve provocar mais desgaste do rebolo. Tal aspecto é analisado a seguir.

\subsection{Análise da força em um grão abrasivo}

Durante os ensaios, as forças de retificação tenderam sempre a um patamar de estabilização numa determinada condição de usinagem, que corresponde ao equilíbrio entre as forças de retificação e as forças de retenção do ligante nos grãos abrasivos. Aqui, as forças de retificação neste patamar de estabilização são designadas por forças de estabilização.

A força tangencial de estabilização em um único grão abrasivo é determinada pela expressão:

$$
F t 1 g=\frac{F_{t}}{l_{R} l_{C} D}
$$

Sendo:

Ft1g : Força tangencial de estabilização em um grão abrasivo [N]

$F t$ : Força tangencial total de retificação de estabilização [N]

$I_{R}$ : largura do rebolo utilizada na operação de retificação [mm]

$I_{C}:$ comprimento de contato $[\mathrm{mm}]$

$D:$ densidade de grãos [grãos $/ \mathrm{mm}^{2}$ ]

A largura do rebolo utilizada nos ensaios foi $5 \mathrm{~mm}$ e densidade de grãos é $21.41 \mathrm{grão} / \mathrm{mm}^{2}$. 
O comprimento de contato foi calculado pela expressão:

$$
l_{c}=\sqrt{a d_{e}}
$$

Sendo:

a: profundidade de corte [mm/rot]

$\mathrm{d}_{\mathrm{e}}$ : diâmetro equivalente [mm]

Durante os ensaios, a força tangencial de estabilização é determinada pelos valores finais das Figuras 4.19, 4.20 e 4.21.

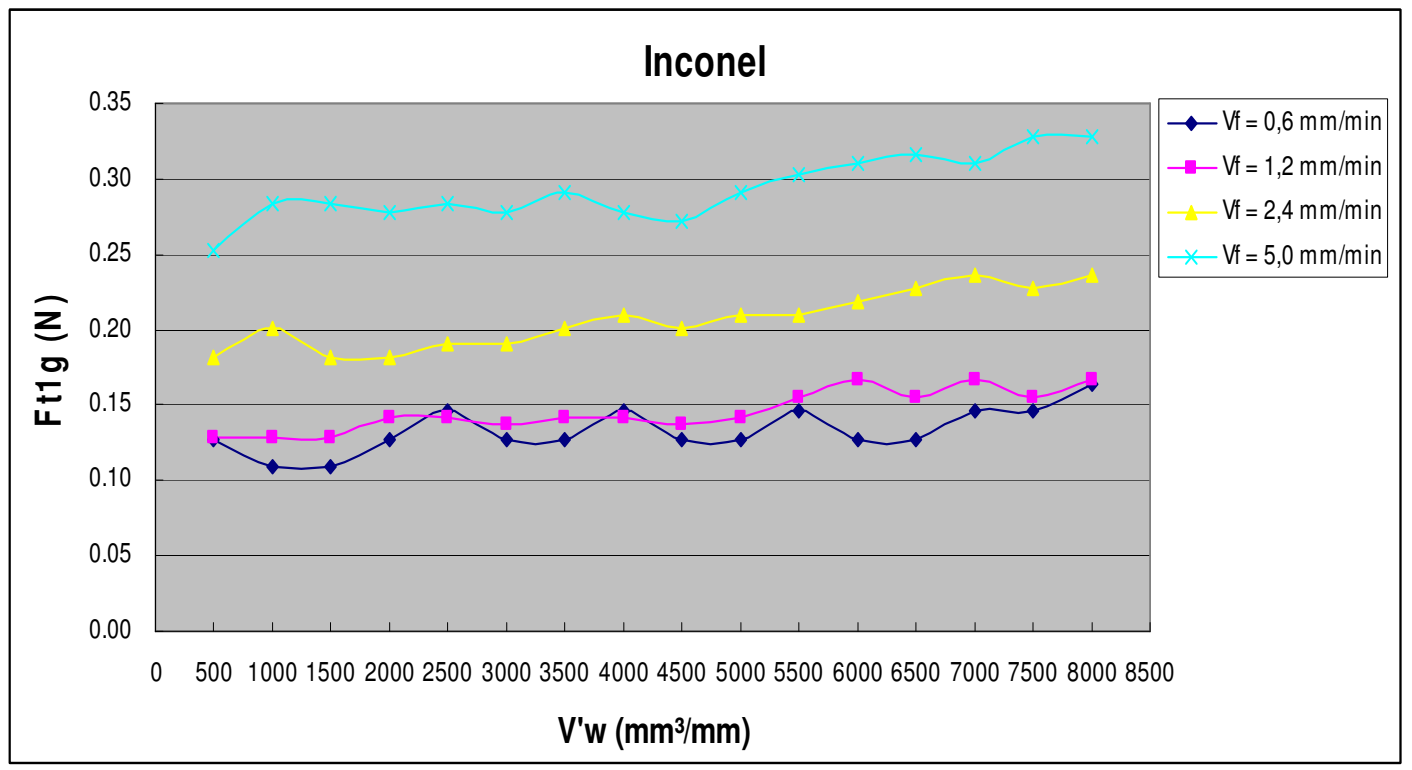

Figura 4.19 - Comportamento de Ft1g para o material Inconel em função do volume específico de material removido V'w. 


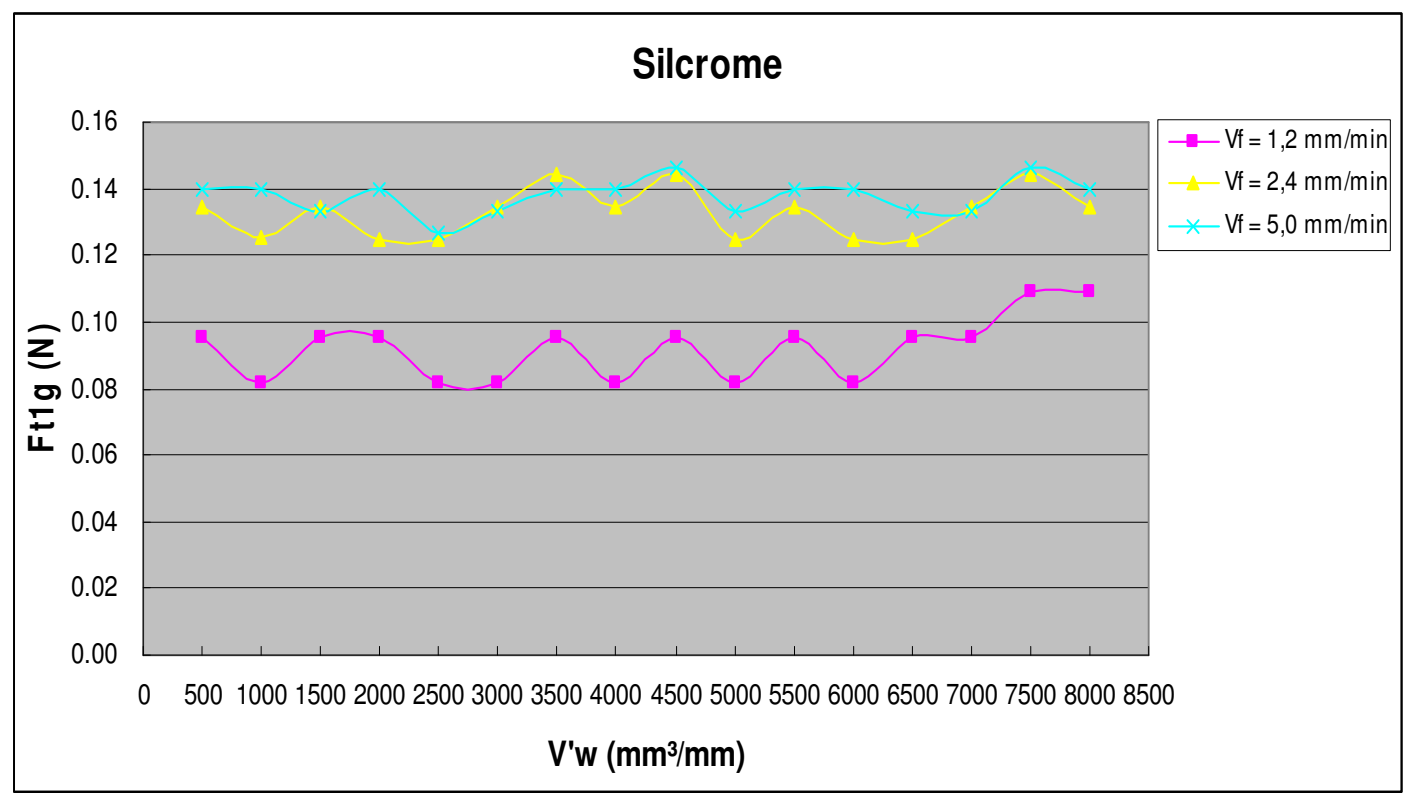

Figura 4.20 - Comportamento de Ft1g para o material Silcrome em função do volume específico de material removido V'w.

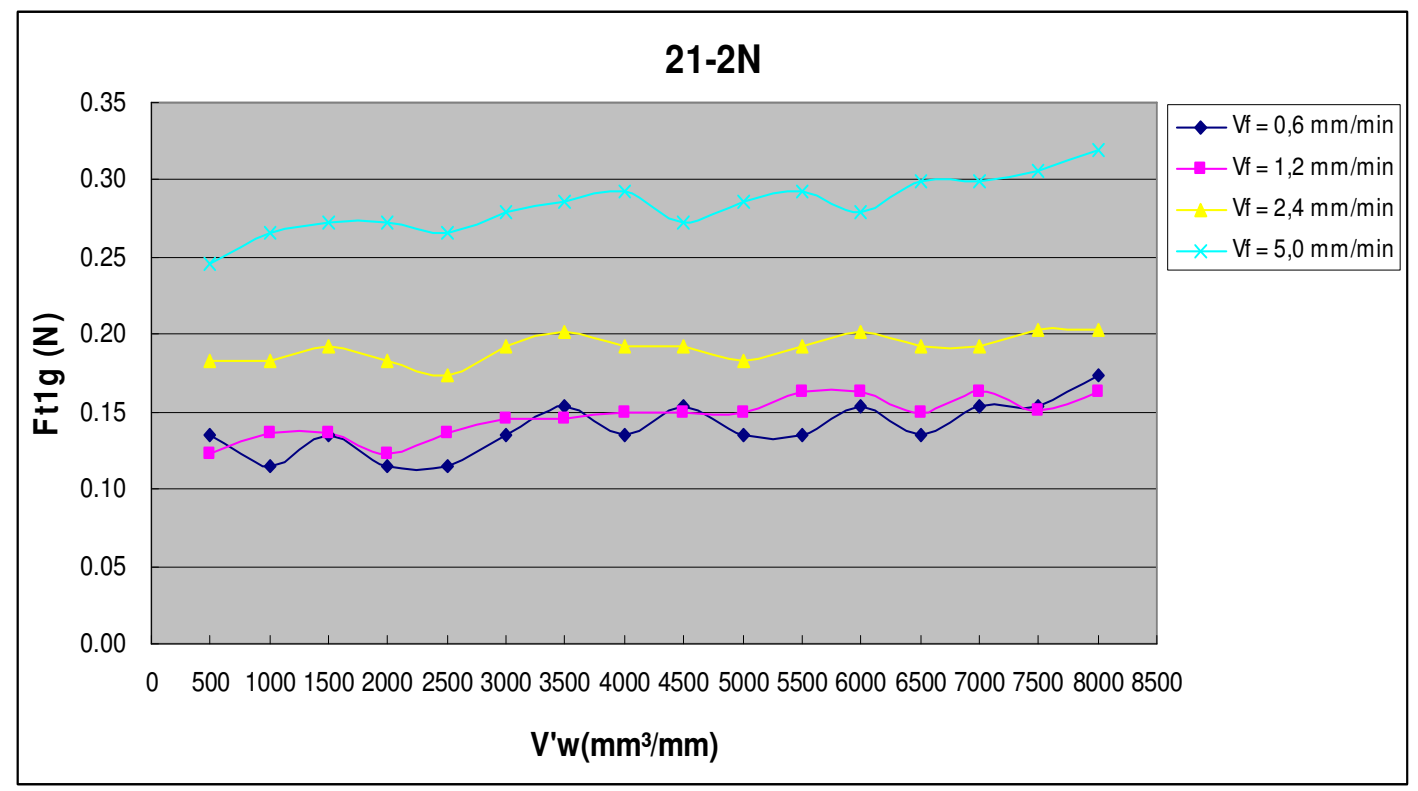

Figura 4.21 - Comportamento de Ft1g para o material 21-2N em função do volume específico de material removido V'w.

Para entender melhor a relação entre a força tangencial de estabilização em um único grão abrasivo e a relação $\mathrm{G}$, foi calculado o valor médio de Ft1g das diferentes velocidades de avanço de cada material e construída a Figura 4.22. 
Se G é função de Ft1g, isso significa que a partir de uma dada força tangencial de estabilização de um grão limite (Ft1g lim), o $G$ deve cair abruptamente. A Figura 4.22 mostra que na presente aplicação o valor de Ft1g limite é aproximadamente de $0.13 \mathrm{~N}$. Um aspecto muito importante é que todos os pontos do gráfico (que incluem diferentes materiais da peça) agrupam-se em uma mesma curva de tendência. Isso significa que o aumento de força por grão abrasivo (causado também por diferentes propriedades do material que são afetadas pela sua composição) é o principal fator relacionado ao desgaste volumétrico. Portanto a concentração de Ni deve ser encarada apenas com um dos fatores que afetam a usinabilidade e, a força de corte.

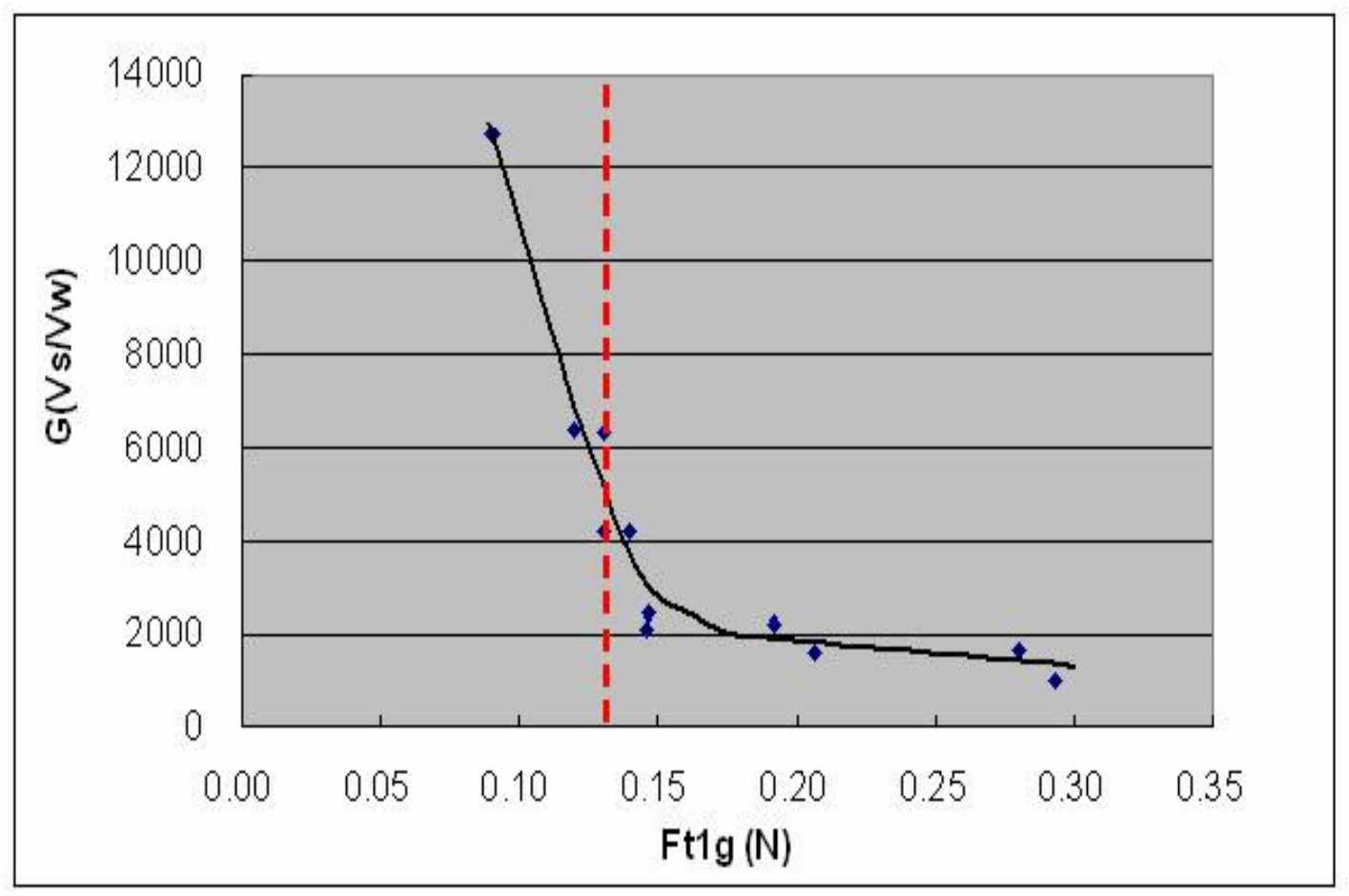

Figura 4.22 - A relação entre força tangencial de estabilização em um único grão abrasivo e a relação $\mathrm{G}$.

É possível então, para um dado rebolo, prever o valor de $\mathrm{G}$ de acordo com a Ft1g obtida pela medição de potência em um teste rápido. Segue a Figura 4.23 que mostra a função logarítmica que passamos a chamar de curva característica do rebolo. Tal curva pode ser uma referência para a predição do valor aproximado da relação G, a partir de um teste de potência. É importante salientar que tal curva é somente válida para cada rebolo, condições de refrigeração da peça e 
rigidez/estabilidade da máquina ferramenta adotadas no teste. Mesmo assim trata-se de uma informação muito útil para se caracterizar uma ferramenta e poder predizer os custos de um processo.

Com os resultados apresentados fica clara a influência da Ft1g no desgaste da superfície de corte do rebolo. A análise feita para materiais fáceis e difíceis de serem retificados permite a utilização destes resultados em diversos ambientes de trabalho das indústrias que usam rebolo CBN. Observou-se que a relação G é inversamente proporcional ao Ft1g. Desta forma, para economizar rebolo deve-se trabalhar com Ft1g mínimo possível.

Um raciocínio similar pode ser formulado para a relação entre a rugosidade e a força em um grão abrasivo. A Figura 4.24 mostra tal relação. Nesse caso há uma dispersão maior, tendo em vista que diversos mecanismos inerentes à formação de cavaco na retificação têm grande influência na rugosidade da peça.

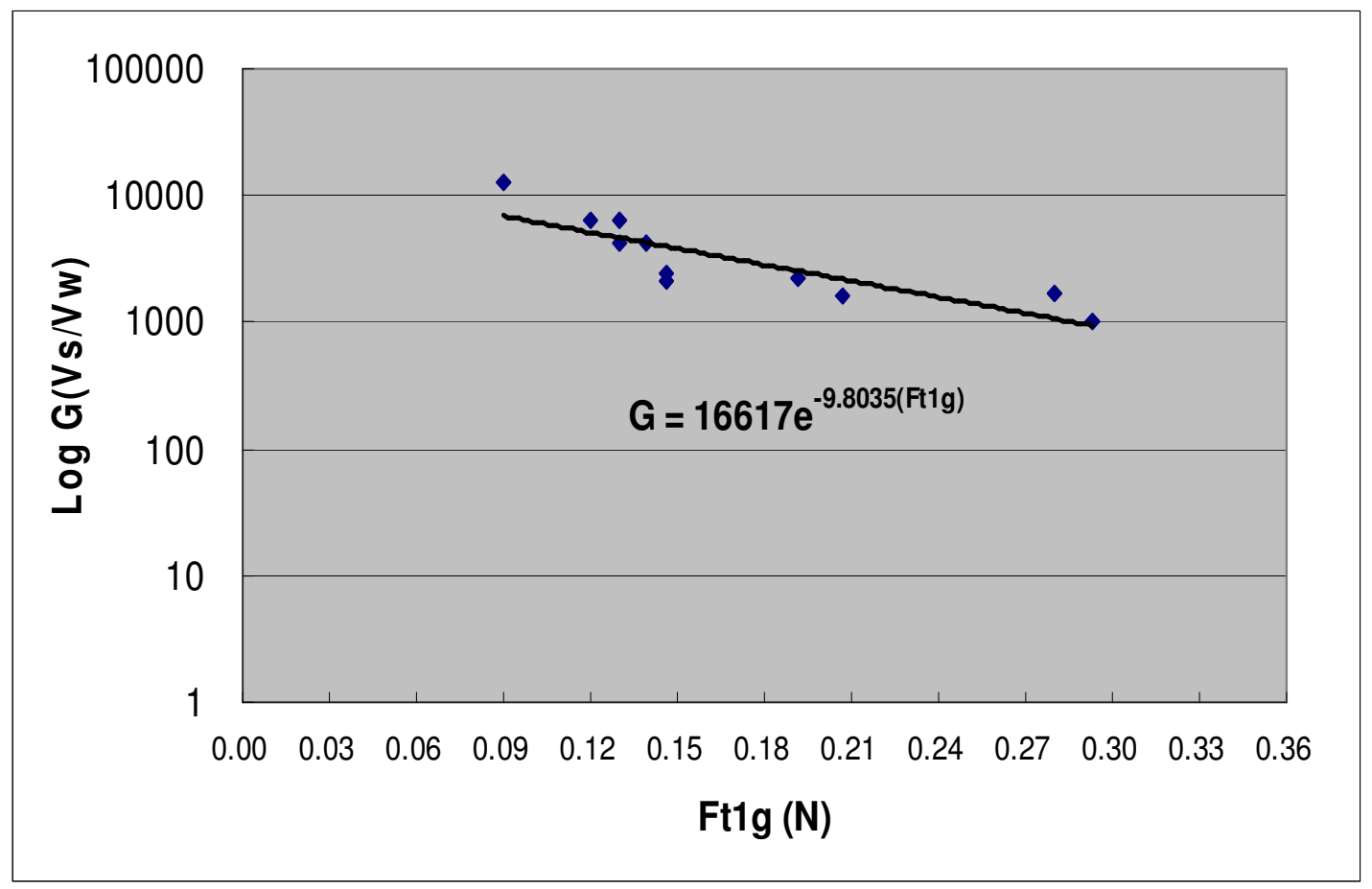

Figura 4.23 - Curva característica do rebolo CBN. 


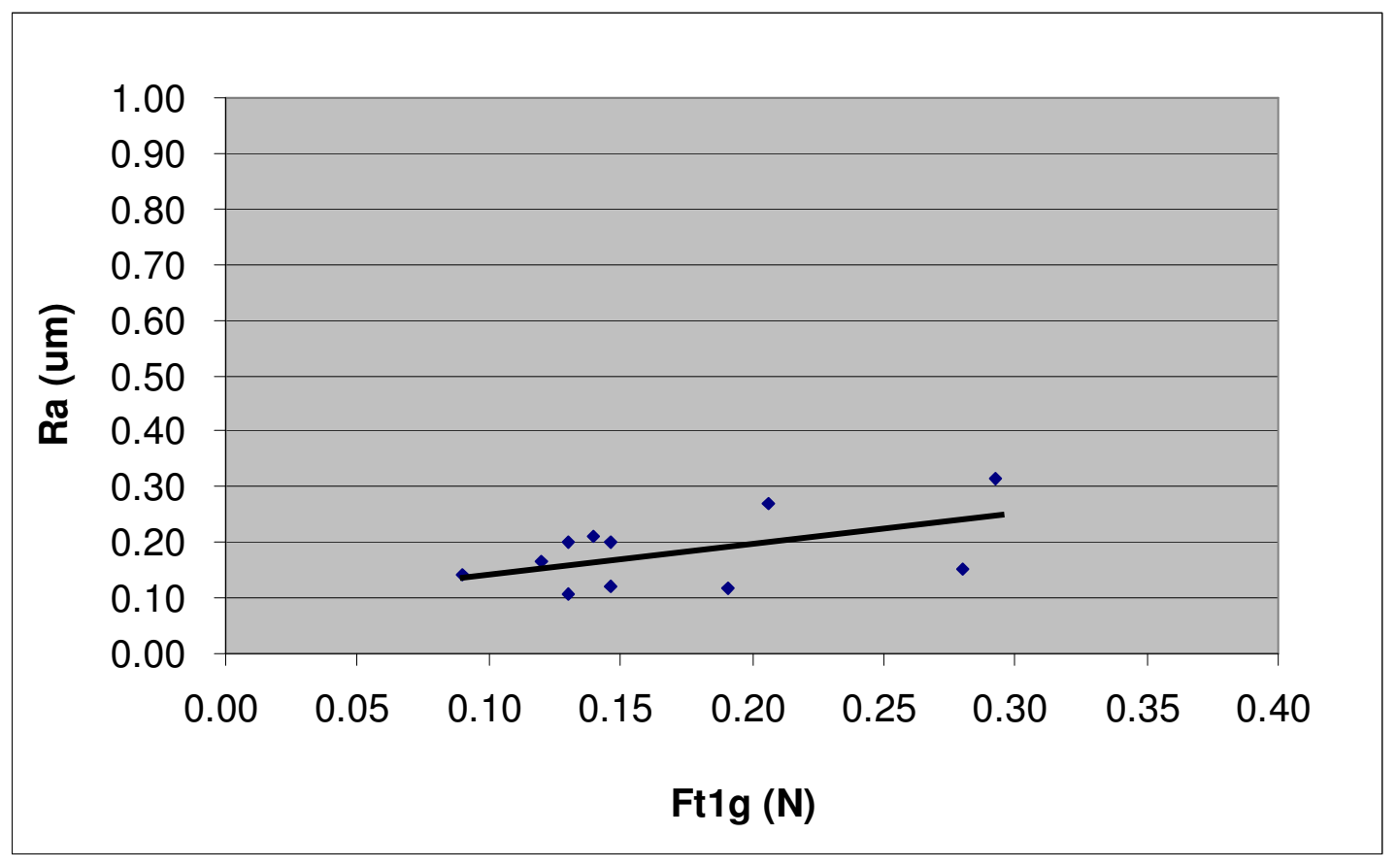

Figura 4.24 - A relação entre força tangencial de estabilização em um único grão abrasivo e a rugosidade.

\subsection{Comentários finais}

De maneira geral o estudo e a análise dos resultados experimentais permitiram uma avaliação criteriosa do desempenho do rebolo CBN. Com esses dados é possível planejar a implantação de CBN na empresa de retificação de componentes.

Basicamente no chão de fábrica, o número de peças retificadas entre duas dressagens consecutivas é usado como base de comparação do desempenho dos rebolos. Na prática, esse parâmetro é simplesmente chamado de número de peças por dressagem (PPD), que expressa diretamente a vida útil do rebolo ou o número de peças por rebolo.

$$
P P D=\frac{V^{\prime} w \max }{V^{\prime} w 1 p}
$$


O valor de V'w max depende do critério de dressagem a ser adotado. A dimensão da peça, a rugosidade ou a circularidade são geralmente os limitadores de qualidade mais utilizados.

A título de exemplo, vamos adotar um desgaste radial máximo admissível em um rebolo de CBN de 2 microns. O sobre-metal retificado de cada peça para esta suposição será de 100 microns. Com a relação entre as variáveis G e Ft1g já encontradas neste trabalho, podemos determinar o valor de PPD para duas condições e dois materiais utilizados.

Usando o rebolo $\mathrm{CBN}$ e as condições de refrigeração da peça e rigidez/estabilidade da máquina ferramenta adotadas neste trabalho, com 2 microns de desgaste radial máximo podemos calcular V's max, que é igual a $2.512 \mathrm{~mm}^{3} / \mathrm{mm}$.

Desta forma, podemos escolher o Inconel e o $21-21 \mathrm{~N}$ com diâmetro de 25 $\mathrm{mm}$ e velocidade de avanço (Vf) $1.2 \mathrm{~mm} / \mathrm{min}$ e $5.0 \mathrm{~mm} / \mathrm{min}$. De acordo com a Figura 4.22, obtemos os valores médios de Ft1g para cada uma das 4 condições acima citadas. Utilizando a fórmula obtida do gráfico da Figura 4.23, pode-se achar os valores da relação $G$ para cada valor de Ft1g.

Com os valores da relação $G$ e V's max calculados, podemos então encontrar V'w max para cada condição. Pela Equação 10, finalmente obtemos os respectivos valores de PPD para cada condição escolhida. Este método de obtenção dos valores de peça por dressagem pode ser de grande importância na elaboração de um plano de fabricação na indústria. A Tabela 8 exibe os valores adotados nesta simulação e os resultados obtidos.

Tabela 8 - Resultado da simulação.

\begin{tabular}{|c|c|c|c|c|c|}
\hline Material & Vf [mm/min] & Ft1g [N] & G & V'w $\mathbf{m a x}\left[\mathrm{mm}^{\mathbf{3}} / \mathbf{m m}\right]$ & PPD \\
\hline $\begin{array}{c}\text { Inconel } \\
\mathbf{7 5 1}\end{array}$ & 5.0 & 0.29 & 968 & 2431 & 620 \\
\cline { 2 - 6 } & 1.2 & 0.15 & 3818 & 9590 & 2448 \\
\hline \multirow{2}{*}{$\mathbf{2 1 - 2 N}$} & 5.0 & 0.28 & 1067 & 2680 & 684 \\
\cline { 2 - 6 } & 1.2 & 0.14 & 4212 & 10580 & 2701 \\
\hline
\end{tabular}


Tal aplicação pode proporcionar benefícios, uma vez que o custo desta ferramenta é elevado e sua utilização de forma não apropriada acarreta em custos ferramental elevados que podem tornar a aplicação de CBN inviável. 


\section{CONCLUSÕES}

Diante dos resultados obtidos no decorrer da análise dos ensaios, pode- se concluir objetivamente que:

> A variação da velocidade de avanço ( $\mathrm{Vf}$ ) do rebolo de CBN foi decisiva para os valores da rugosidade $\mathrm{Ra}$, o aumento da velocidade de avanço (Vf) gera uma maior rugosidade na peça.

$>$ Observou-se que para condições mais severas nos materiais mais difíceis de retificar, ocorre um crescimento maior da rugosidade ao longo dos testes.

> Quanto maior for a velocidade de avanço (Vf), maior será a potência consumida no processo de retificação, os materiais apresentam os maiores valores de potência consumida no processo por possuírem pior usinabilidade.

> A taxa de desgaste do rebolo aumenta com o aumento da velocidade de avanço. Quanto pior a usinabilidade do material, maior será desgaste do rebolo.

> O valor do parâmetro G para rebolo de CBN vitrificado é influenciado tanto pelo tipo do material retificado quanto pelo valor da velocidade de avanço utilizada no ciclo de retificação.

> Observou-se que a partir de um dado valor limite de Ft1g (Ft1g lim), o G deve cair abruptamente e a relação G é inversamente proporcional ao Ft1g. Para economizar rebolo deve-se trabalhar com Ft1g mínimo possível. Nas condições adotadas neste trabalho Ft1g limite é aproximadamente de 0.13 $\mathrm{N}$.

$>$ A rugosidade cresce com o valor de Ft1g, entretanto há outros mecanismos de formação de cavaco que influenciam em seu resultado.

> Com esse trabalho é possível entender melhor as influências no desgaste de rebolos de CBN vitrificado, tendo em vista a avaliação da força em um grão abrasivo. Tal relação permite prever a quantidade de peças a serem produzidas por operação de dressagem, necessitando apenas um teste para a medição da potência consumida nas condições de trabalho para se 
calcular a força em um grão abrasivo, que posteriormente será comparada com a curva característica do rebolo.

Ao finalizar, pode-se afirmar que dentro dos objetivos previstos, este trabalho trouxe importantes contribuições no sentido de elucidar a retificação com alta velocidade de superligas à base de níquel. Porém, é necessário mais investigações com altas velocidades e avanços para que se tenha um melhor desempenho, principalmente quanto a vida da ferramenta. 


\section{SUGESTÕES PARA TRABALHOS FUTUROS}

Com base nos estudos realizados e nas conclusões alcançadas, as sugestões são:

- Estudar a influência das vibrações no desgaste do rebolo e desenvolver um sistema de amortecimento que seja possível tornar o processo aceitável utilizando o rebolo de CBN na retificação de superligas em alta velocidade.

- A vibração também é um fator importante sobre a taxa de desgaste do rebolo. Assim, recomenda-se em trabalhos futuros a associação da composição química do material com o tratamento térmico e vibrações no processo de retificação, a fim de se estabelecer a real influência de cada fator sobre a taxa de desgaste do rebolo de CBN vitrificado e com esses dados é possível planejar a implantação de CBN na empresa de retificação de componentes.

- Desenvolver um sistema modular para checar a rebolos de retificação que fossem ao mesmo tempo de corte livre e com redução de desgaste.

- Verificar o desgaste do rebolo em testes de retificação mais longos, com maior volume de material removido.

- Investigar a retificabilidade de outras ligas de $\mathrm{Ni}$, por exemplo, o Inconel 718 e 901. 


\section{REFERÊNCIAS BIBLIOGRÁFICAS}

1. ALVES, S. M. Adequação ambiental do processo de retificação através de um novo conceito de fluido de corte. Tese (Doutorado em Engenharia Mecânica) Escola de Engenharia de São Carlos - Universidade de São Paulo, São Carlos, 2005.

2. BIANCHI, E. C. Ação da geometria teórica do cavaco no desgaste de rebolos de CBN com ligante resinóide. Tese (Doutorado em Engenharia Mecânica) Escola de Engenharia de São Carlos - Universidade de São Paulo, São Carlos, 1992.

3. BIANCHI, E. C.; FERNANDES, O. C.; VALARELLI, I. D. D.; SILVA, E. J.; XAVIER, A. P.; SPINELLI, J. E.; NEVES, R. C.; MONICI R. D.; CAGNIN, A. R.; SOUZA, G. F.; ALVES, A.S. A contribuição dos rebolos superabrasivos com ligantes resinóide e vitrificado. Máquinas e Metais. n.398, p.88 - 113, Março, 1999.

4. BRINKSMEIER, E.; HEINZEL, C.; MEYER, L. Development and Application of a Wheel Based Process Monitoring System in Grinding. Annals of CIRP, v. 54/1, p. 301-304, 2005.

5. BYRNE, G. Tool condition monitoring (TCM) - the status of research and industrial application. Annals of the CIRP. p. 1-27, 1995.

6. CARIUS, A. C. Desenvolvimentos de produto e do mercado de CBN na América e na Europa. Revista Máquinas e Metais, no 403, p. 86-103, Agosto, 1999.

7. CHEN, X.; ROWE, W. B.; CAI, R. Precision grinding using CBN wheels. International Journal of Machine Tools \& Manufacture 42, pp.585-593, 2002.

8. CHOUDHURY, I. A.; EL-BARADIE, M. A. Machinability of nickel-base super alloys: a general review. Journal of Materials Processing Technology. v.77, p.278284, 1998.

9. DORNFELD, D. A. Monitoração de processos por emissão acústica. Revista Máquinas e Metais, Editora Aranda, no 400, p. 64-81, maio, 1999.

10. EZUGWU, E. O.; WANG, Z .M.; MACHADO, A. R. The machinability of nickelbased alloys: a review. Journal of Materials Processing Technology. v.86, p.1-16, 1999.

11. HASSUI, A.; DINIZ, A.E.; OLIVEIRA, J.F.G.; FELIPE, J.; GOMES, J.J.F. Experimental evaluation on grinding wheel wear through vibration and acoustic emission. Wear, 217, p.7-14, 1998. 
12. HITCHINER, M. P. O emprego da ata velocidade com rebolos de CBN. Revista Máquinas e Metais, Editora Aranda, no 428, p. 116-133, setembro, 2001(a).

13. HITCHINER, M. P. Advantages in Production Grinding with CBN and their Influence on Machine Tool Design. Saint Gobain Grinding Conference, São Carlos, São Paulo, Junho 2001(b), em CD.

14. HOWES, T. Assessment of the Cooling and Lubricative Properties of Grinding Fluids. Annals of CIRP, v. 39/1, p. 313-316, 1990.

15. ICHIDA, S. Y. Creep feed profile grinding of Ni-based superalloys with ultrafinepolycrystalline cBN abrasive grits, Journal of the International Societies for Precision Engineering and Nanotechnology, vol. 25, p. 274-283, 2001.

16. ICHIDA, Y. \& KISHI, K. The development of nanocrystalline CBN for enhanced superalloy grinding performance. Journal of Manufacture Science and Engineering, vol. 119, p. 110-117, 1997.

17. JACKSON, M. J.; DAVIS, C. J.; HITCHINER, M. P.; MILLS, B. High-speed grinding with $\mathrm{CBN}$ grinding wheels - applications and future technology. Journal of Materials Processing Technology, no 110, p.78-88, 2001.

18. JACKSON, M. J.; MILLS, B. Microscale wear of vitrified abrasive materials. Journal of Materials Science. no 39, p.2131-2143, 2004.

19. KARPUSCHEWISKI, B. Sensor for physical properties. In: TÖNSHOFF, H. K.\& INASAKI, I. Sensors in Manufacturing Vol.1. Wiley-VCH. Cap.3, p.123-142, 2001.

20. KING, R. I. \& HAHN, R. S. Handbook of Modern Grinding Technology. Chapman and Hall, 1986, 360p.

21. KLOCKE, F.; BRINKSMEIER, E.; EVANS, C.; HOWES, T.; INASAKI, I.; MINKE, E.; Tönshoff, H. K.; WEBSTER, J. A.; STUFF, D. High-Speed Grinding Fundamentals and State of the Art in Europe, Japan, and the USA. Annals of CIRP, v. 46/2, p. 715-724, 1997.

22. KLOCKE, F. \& KÖNIG, W. Appropriate conditioning strategies increase the performance capabilities of vitrified-bond CBN grinding wheels. Annals of CIRP, v.44/1, p. 305-310, 1995.

23. KOPAC, J. \& KRAJNIK, P. High-performance grinding - A review. Journal of Materials Processing Technology. no 175, p.278-284, 2006.

24. LEE, D. E.; HWANG, I.; VALENTE, C. M. O.; OLIVEIRA, J. F. G.; DORNFELD, D. A. Precision manufacturing process monitoring with acoustic emission. International Journal of Machine Tools \& Manufacture 46, p.176-188, 2006. 
25. MACHADO, A. R. \& DINIZ, A. E. Vantagens e desvantagens do uso (ou não) de fluidos de corte. Revista Máquinas e Metais, no 419, p.134-139, Dezembro, 2000.

26. MALKIN, S. Grinding Technology: Theory and Applications of Machining with Abrasives. 1ed., Chichester: Ellis Horwood, 1989, 275p.

27. NOVASKI, O. \& RIOS, M. Introdução teórica e vantagens de uso na usinagem de aço liga. Revista Máquinas e Metais, Editora Aranda, no 460, p. 214-223, maio, 2004.

28. OLIVEIRA, J. F. G. Análise da ação do macroefeito de dressagem de rebolos no desempenho do processo de retificação. Tese (Doutorado em Engenharia Mecânica) - Escola de Engenharia de São Carlos - Universidade de São Paulo, São Carlos, 1988.

29. OLIVEIRA, J. F. G. \& DORNFELD, D. A. Application of AE Contact Sensing in Reliable Grinding Monitoring. Annals of CIRP, v.50/1, p. 217-220, 2001.

30. SALMON, S. C. Modern grinding process technology. McGraw-Hill, 1992, $225 p$.

31. SCHUITEK, A. J.; SEVERIANO, A. C.; BELLOS, N. L. Um caso bem-sucedido de uso de rebolos de CBN. Máquinas e Metais, n.429, p.112-125, Outubro, 2001.

32. SILVA, C. E. Jr. \& COELHO, R. T. Dressagem de rebolos para aplicações de precisão. Revista Máquinas e Metais, no 393, p.100-111, Outubro, 1998.

33. SILVA, E. J. Análise de estratégias de retificação de virabrequins automotivos forjados utilizando rebolos de CBN vitrificados em altas velocidades. Tese (Doutorado em Engenharia Mecânica) - Escola de Engenharia de São Carlos Universidade de São Paulo, São Carlos, 2004.

34. SIMS, C. T.; STOLOFF, N. S.; HAGEL, W. C. Superalloys II, A WileyInterscience publication, $1987,615 \mathrm{p}$.

35. TÖNSHOFF, H. K.; JUNG, M.; MÄNNEL, S.; RIETZ, W. Using acoustic emission signals for monitoring of production processes. Ultrasonics 37, p. 681686,2000 .

36. TÖNSHOFF, H. K.; PETERS, J.; INASAKI, I.; PAUL, T. Modeling and Simulation of Grinding Processes, Annals of the CIRP, Vol. 41/2, p.677-688, 1992.

37. VARGHESE, B.; PATHARE, S.; GAO, R.; GUO, C.; MALKIN. S. Development of a sensor-integrated intelligent grinding wheel for in-process monitoring. Annals of CIRP, v. 49/1, p. 231-234, 2000.

38. VIGNEAU, J. Obtendo alta produtividade na usinagem de ligas de titânio e superligas. Máquinas e Metais, n.380, p.16-31, Setembro, 1997. 
39. WEBSTER, J. A.; CUI, C.; MINDEK Jr, R. B. Grinding fluid application system design. Annals of CIRP, v. 44/1, p. 333-338, 1995.

40. WEINGAERTNER, W. L.; TABORGA, A. R. M.; TABORGA, J. D. M. Análise dos danos térmicos na retificação. In: XVI COBEM, ABM, Vol. 14, p. 334-342, 2001.

41. XU, W. P.; YU, Y. Q.; XU, H. J. Effect of grinding temperatures on the surface integrity of a nickel-based superalloy. Journal of Materials Processing Technology 129, p.359-363, 2002.

42. XU, X. \& YU, Y. XPS and SEM characterization of wheel/workpiece interface in grinding of superalloy. Surface and Interface Analysis 33. p.343-350, 2002.

43. YUI, A. \& LEE, H. Surface Grinding with ultra high speed CBN wheel. Journal of Materials Processing Technology, v.62, p.393-396, 1996. 


\section{ANEXOS}

\section{ANEXO I}

Programa para ensaio de retificação de desgaste do rebolo.

O1520(MERGULHO GM)

N10 \#1=88.070(DIAM. BRUTO);

N15 \#2=-8.000(POS. INI. EM Z);

N20 \#3=0.42(SM DESBASTE);

N30 \#4=0(SM SEMI-ACABAMENTO);

N35 \#5=0(SM ACABAMENTO);

N40 \#6=5.0(AVANCO DESBASTE);

N50 \#7=0(AVANCO SEMI-ACAB);

N60 \#8=0(AVANCO ACABAMENTO);

N70 \#9=0.5(TEMP. SPARK-OUT ACAB.);

N80 \#10=200(ROTACAO PECA);

N90 \#11=1(OSC SIM =0);

N95 \#12=400(NR PECAS/DRESSAGEM);

N96 \#13=0(COMPENSACAO DIA.);

N97 \#14=1(NUM. CICLOS);

N100 G94;

N105 M61;

N110 G0X[\#500+2.0];

N120 M3S\#10;

N130 G0Z\#2; 
N140 X[\#1+0.117]M8;

N150 G1X[\#1]F\#6;

N160 G01U[-\#3+\#13]F\#6;

N170 G01U-\#4F\#7;

N175 G01U-\#5F\#8;

N180 G04X\#9;

N181 \#532=\#5041;

N182 \#14=[\#14-1];

N183 IF[\#14NE0]GOTO160;

N185 IF[\#11EQ1]GOTO200;

N195 G01W-5.F200;

N196 W5.0;

N197 G04X0.1;

N200 G00X[\#500+2.0];

N210 G65P9000C\#12Q9;

N310 M9;

N320 M5;

N325 M62;

N330 M30; 
Programa de dressagem utilizado nos experimentos.

O0009(AUXILIAR DRESS);

N10 M51;

N20 G4X12.0;

N30 T0000;

N35 M61;

$\mathrm{N} 40 \# 5=\# 619$;

N45 IF[\#640EQ1]GOTO50;

N47 G65P1091;

N50 G65P1090;

$\mathrm{N} 60$ \#5=[\#5-1];

N70 IF[\#5NE0]GOTO50;

N80 M9;

N85 M52;

N87 M62;

N90 M30; 
(SUB PROG O1090)

\#619=2(REPETICOES DE DRESS);

\#620=0.040(INCR. X DRESS DIAM);

\#621=0.000(INCR. Z DE DRESS);

\#622=300(VELOCIDADE DRESSAGEM);

\#623=150(VEL MERGULHO DRESSADOR);

\#624=55(LARGURA DO REBOLO);

$\# 690=\# 606$;

$\# 640=1($ REF EA $0=S 1=N)$; 